$$
\text { UNIVERSIDADE DE SÃO PAULO }
$$

FACULDADE DE FILOSOFIA, LETRAS E CIÊNCIAS HUMANAS DEPARTAMENTO DE LETRAS MODERNAS PROGRAMA DE PÓS-GRADUAÇÃO EM ESTUDOS LINGUÍSTICOS, LITERÁRIOS E TRADUTOLÓGICOS EM FRANCÊS

\title{
ARRIVISMO FEMININO EM MACHADO DE ASSIS E MARCEL PROUST
}

Maria Elvira Lemos da Silva

(Versão corrigida)

São Paulo

2016 


$$
\text { UNIVERSIDADE DE SÃO PAULO }
$$

FACULDADE DE FILOSOFIA, LETRAS E CIÊNCIAS HUMANAS DEPARTAMENTO DE LETRAS MODERNAS PROGRAMA DE PÓS-GRADUAÇÃO EM ESTUDOS LINGUÍSTICOS, LITERÁRIOS E TRADUTOLÓGICOS EM FRANCÊS

\section{ARRIVISMO FEMININO EM MACHADO DE ASSIS E MARCEL PROUST}

Maria Elvira Lemos da Silva

Tese apresentada ao Programa de Pós-Graduação em Estudos Linguísticos, Literários e Tradutológicos em Francês, do Departamento de Letras Modernas da Faculdade de Filosofia, Letras e Ciências Humanas da Universidade de São Paulo, para a obtenção do título de Doutora em Letras.

Orientador: Prof. Dr. Gilberto Pinheiro Passos

(Versão Corrigida)

São Paulo 
AUTORIZO A REPRODUÇÃO E DIVULGAÇÃO TOTAL OU PARCIAL DESTE TRABALHO, POR QUALQUER MEIO CONVENCIONAL OU ELETRÔNICO, PARA FINS DE ESTUDO E PESQUISA, DESDE QUE CITADA A FONTE.

SILVA, Maria Elvira Lemos da.

Arrivismo feminino em Machado de Assis e Marcel Proust/ Maria Elvira Lemos da Silva; orientador Gilberto Pinheiro Passos.

São Paulo, 2016.

$210 f$.

Tese (Doutorado - Programa de Pós-graduação em Letras. Área de concentração: Estudos Linguísticos, Literários e Tradutológicos em Francês)

- Faculdade de Filosofia, Letras e Ciências Humanas da Universidade de São Paulo.

1. Machado de Assis - 2. Marcel Proust - 3. Literatura comparada -4. Arrivismo - 5. Personagens femininas. 
Para Sadi 


\section{Agradecimentos}

Ao Professor Gilberto Pinheiro Passos, pela orientação precisa e pela grande generosidade demonstrada ao longo de todos esses anos.

À Professora Glória Carneiro do Amaral, pelas preciosas sugestões no exame de qualificação e por estar presente em todas as etapas de avaliação de minhas pesquisas, desde o Mestrado.

Aos meus pais, Clayton e Maria Regina, pelo apoio incondicional.

Ao meu irmão João, por ter participado diretamente da escolha do curso de Letras e dos anos da Graduação.

A Isabella e Jéssica, pela presença fundamental em minha vida.

À CAPES, pelo apoio financeiro. 
A vontade e a ambição, quando verdadeiramente dominam, podem lutar com outros sentimentos, mas hão de sempre vencer, porque elas são as armas do forte, e a vitória é dos fortes.

Machado de Assis, A mão e a luva 


\section{Resumo}

SILVA, M.E.L.da. Arrivismo feminino em Machado de Assis e Marcel Proust. 2016. 210f. Tese (Doutorado) - Faculdade de Filosofia, Letras e Ciências Humanas, Universidade de São Paulo, 2016.

Esta tese traz a análise das personagens arrivistas femininas das obras romanescas de Machado de Assis e Marcel Proust. São elas: Guiomar, Helena e Sofia, de A mão e a luva, Helena e Quincas Borba, respectivamente, e Odette e Madame Verdurin de À la recherche du temps perdu.

Em A Mão e a luva e Helena, Machado engendra as tramas no Rio de Janeiro dos anos 1850, período estável do Segundo Reinado. A trajetória ascensional de Guiomar e Helena, em uma época de pouca mobilidade social, justifica-se pelo fato de serem personagens singulares, dotadas de grande habilidade. Aqui, o destino repara o equívoco do nascimento desprivilegiado. Quincas Borba, por outro lado, ambientado entre 1867 e 1871, apresenta uma sociedade mais dinâmica e fluida. A mudança gradativa de classes operada por Sofia e Cristiano Palha se deve ao grande senso de oportunismo nos negócios e às ações pouco escrupulosas do casal. De todo modo, as narrativas brasileiras tratam predominantemente do desejo de pertencer à burguesia rica.

Em À la recherche du temps perdu, Proust mostra uma sociedade complexa e estratificada, em que a burguesia e a nobreza, a despeito da Revolução Francesa, continuam divididas em várias subcategorias na Belle Époque. Por isso, Odette e Madame Verdurin têm de cumprir muitas etapas no decorrer de quatro décadas para conquistarem seu espaço no faubourg SaintGermain.

Considerando as diferenças históricas e espaciais dos romances brasileiros e franceses, analisamos a construção das figuras femininas citadas através do cotejamento de trechos das obras. Com isso, foi-nos possível apontar pontos de aproximação como o casamento, a maternidade e a importância dos salões, vistos sob os pontos de vista das condições sócioculturais de cada país.

Palavras-chave (5): Machado de Assis; Marcel Proust; literatura comparada; arrivismo; personagens femininas. 


\begin{abstract}
SILVA, M.E.L.da. Female social-climber characters in Machado de Assis and Marcel Proust. 2016. 210p. Thesis (PhD) - Faculdade de Filosofia, Letras e Ciências Humanas, Universidade de São Paulo, 2016.
\end{abstract}

This thesis provides an analysis of female social-climber characters in the novels of Machado de Assis and of Marcel Proust. They are: Guiomar, Helena, and Sofia, from A mão e a luva, Helena, and Quincas Borba, respectively; and Odette and Madame Verdurin, from À la recherche du temps perdu.

In A Mão e a luva and in Helena, Machado unwinds his plot in the Rio de Janeiro of the 1850s, a stable period of the Second Reign. The upwards trajectory of Guiomar and Helena during a time of limited social mobility is justified by the fact that they are singular characters, gifted with great abilities. Here, destiny corrects the mistake of underprivileged birth. Quincas Borba, on the other hand, set between 1867 and 1871, presents a more dynamic and fluid society. The gradual changes in class accomplished by Sofia and Cristiano Palha is a result of the couple's enormous sense of opportunism in business and the relative lack of scruples in their actions. Regardless, the Brazilian stories deal predominately with the desire to belong to the wealthy bourgeoisie.

In À la recherche du temps perdu, Proust shows a complex and stratified society where the bourgeoisie and nobility, in spite of the French Revolution, continue to be divided into various categories of the Belle Époque. As a result, Madame Verdurin has to pass through many stages during a period of four decades to conquer her space in the faubourg of Saint-Germain.

Considering the historical and spatial differences between the Brazilian and French novels, we analyze the construction of the abovementioned female characters through a comparison of excerpts from the works. In so doing, it was possible for us to show points of similarity, such as marriage and maternity and the importance of salons, viewed through the eyes of each country's sociocultural conditions.

Keywords (5): Machado de Assis; Marcel Proust; comparative literature; arrivism; female characters. 


\section{Résumé}

SILVA, M.E.L.da. Arrivisme féminin chez Machado de Assis et Marcel Proust. 2016. 210f.Thèse (Doctorat) - Faculdade de Filosofia, Letras e Ciências Humanas, Universidade de São Paulo, 2016.

Cette thèse présente l'analyse des personnages arrivistes féminins des œuvres romanesques de Machado de Assis et Marcel Proust: Guiomar, Helena et Sofia de $A$ mão e a luva, Helena et Quincas Borba, respectivement, et Odette et Madame Verdurin de À la recherche du temps perdu.

Dans $A$ Mão e a luva e Helena, Machado engendre l'intrigue à Rio de Janeiro dans les années 1850, période stable de l'Empire de D. Pedro II. La trajectoire ascensionnelle de Guiomar et Helena, durant une époque de faible mobilité sociale, se justifie grâce à la création de personnages singuliers, dotés d'une grande habileté. Ici, le destin répare l'équivoque de la naissance défavorisée. Quincas Borba, d'autre part, dans un cadre historique différent (1867 et 1871), présente une société plus dynamique et fluide. Le changement graduel des classes opéré par Sofia et Cristiano Palha a pour base leur opportunisme dans les affaires et les actions peu scrupuleuses du couple. De toute manière, les récits brésiliens traitent principalement de l'envie d'appartenir à la riche bourgeoisie.

Dans À la recherche du temps perdu, Proust montre une société complexe et stratifiée, dans laquelle la bourgeoisie et la noblesse, malgré la Révolution Française, restent divisées en plusieurs sous-catégories durant la Belle Époque. C'est pour cela qu'Odette et Madame Verdurin doivent passer par de nombreuses étapes au cours de quatre décennies pour conquérir leur espace dans le faubourg Saint-Germain.

Au vu des différences historiques et spatiales des romans brésiliens et français, nous avons analysé la construction des figures féminines citées à travers la comparaison d'extraits des œuvres. Grâce à cela, il nous a été possible de cibler des points d'approche comme le mariage, la maternité et l'importance des salons, vus sous l'angle des conditions socioculturelles de chaque pays.

Mots-clés (5): Machado de Assis; Marcel Proust; littérature comparée; arrivisme; personnages féminins. 


\section{Referências das edições usadas}

As citações dos romances de Machado de Assis foram feitas a partir da Obra completa, publicada no Rio de Janeiro pela Editora Nova Aguilar em 1959, volumes I e II.

As citações de À la recherche du temps perdu, de Marcel Proust, foram feitas a partir da coleção da Bibliothèque de la Pléiade, em quatro tomos, publicados pela Gallimard sob a direção de Jean-Yves Tadié, entre 1987 e 1989. Eles estão organizados assim:

Tomo I: Du côté de chez Swann

À l'ombre des jeunes filles en fleurs, I

Tomo II: À l'ombre des jeunes filles en fleurs, II

Le Côté de Guermantes

Tomo III: Sodome et Gomorrhe

La Prisonnière

Tomo IV: Albertine disparue

Le Temps retrouvé 


\section{Sumário}

\section{Capítulo I}

Premissas do tema

Arrivismo feminino em Machado e Proust .................................................13

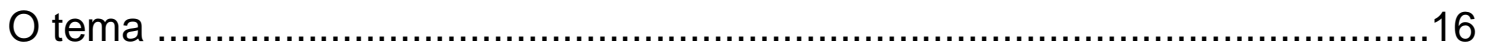

O Segundo Reinado e a Belle Époque ............................................. 24

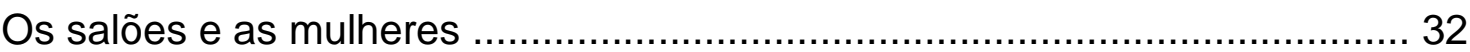

\section{Capítulo II}

\section{Primeiros passos}

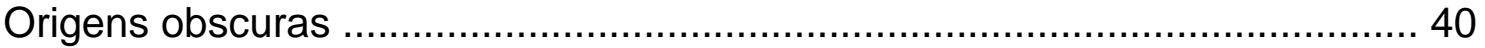

Adaptação notável de Guiomar e Helena .............................................. 52

O casamento como melhor opção ..................................................... 65

Primeiros tempos em Santa Teresa ..................................................... 72

O salão da Rua Montalivet .............................................................. 79

\section{Capítulo III}

Transições

Guiomar e a questão da escolha ..................................................... 94

As (im)possibilidades de casamento em Helena ..................................108

União e divisão: os espaços de A mão e a luva e Helena ...........................115

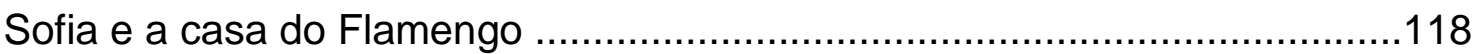

Odette Swann e seu salão literário .......................................................126 
Os Guermantes e a tradição aristocrática

Evolução do salão Verdurin

\section{Capítulo IV}

Consolidações

A conquista de Guiomar

A redenção de Helena 154

Sofia em Botafogo: a inversão do espaço 159

Odette e Madame Verdurin: o reencontro no grand monde 164

\section{Capítulo V}

\section{Arrivismo feminino como articulador narrativo}

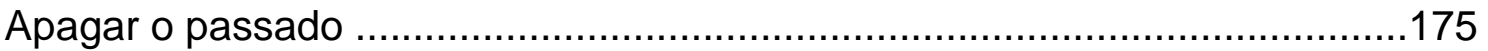

Substituição das personagens.......................................................183

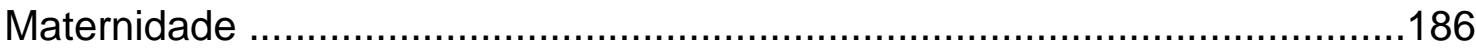

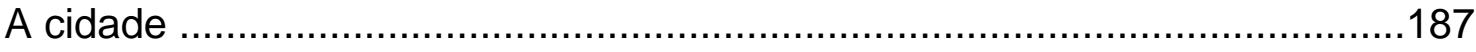

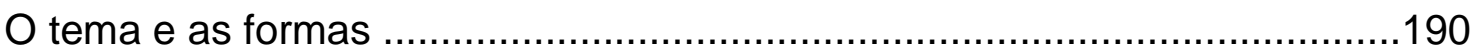

Arrivismo feminino como articulador narrativo ....................................195

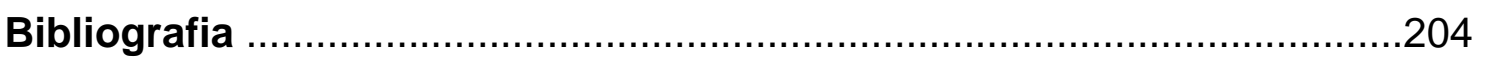




\section{Capítulo I}

\section{Premissas do tema}

Arrivismo feminino em Machado e Proust

Nas obras romanescas de Machado de Assis e Marcel Proust, podemos constatar a predominância da representação do arrivismo social feminino, quando comparada ao masculino. Guiomar, Helena e Sofia, de A mão e a luva, Helena e Quincas Borba, respectivamente, e Odette e Madame Verdurin, de $\grave{A}$ la recherche du temos perdu, podem ser consideradas as figuras de maior força dessas narrativas no que se refere à mudança de classe.

Em A mão e a luva, Luís Alves, o parceiro ambicioso de Guiomar, começa a ser descrito de fato somente a partir da segunda metade do texto e sua presença tem função de complementar o perfil de Guiomar. As qualidades do pretendente eleito ecoam as características já mencionadas da protagonista. Ela o escolhe dentre três opções, portanto sua vontade prevalece.

No caso de Helena, Camargo, personagem explicitamente arrivista, cumpre o papel de antagonista da heroína. Ao pretender ascender por meio do casamento conveniente de sua filha com Estácio, o médico e velho amigo da família causa alguns transtornos a Helena, mas sua atuação fica circunscrita a 
alguns poucos episódios, sendo pouco relevante no desenvolvimento geral da trama.

Entre o casal Palha, de Quincas Borba, se Cristiano parece atuar mais no campo dos negócios, a movimentação social de Sofia se mostra mais determinada. Ela se dispõe a formar a Comissão das Alagoas, renova com mais firmeza o círculo de amizades da família e direciona constantemente o comportamento do marido: "Cristiano, fique mais senhor de si, quando tivermos gente de fora, não se ponha com os olhos fora da cara, saltando de um lado para outro, assim com ar de criança que recebe doce..."1. Outra figura ambiciosa, o jornalista Camacho, aproveita-se das manias de grandeza de Rubião para tirar-Ihe dinheiro, mas sua suposta ascensão é mencionada en passant e sua presença ocupa um pequeno espaço no romance.

Na Recherche, Morel e Bloch são personagens relevantes, mas o narrador se detém nelas em momentos bem delimitados da obra. O violinista desempenha um papel importante em Sodome et Gomorrhe, sobretudo para complementar a movimentação do barão de Charlus, esta sim uma das figuras principais, cuja presença é constante do início ao fim. Do mesmo modo, Bloch surge algumas vezes, em À l'ombre des jeunes filles en fleurs, como dramaturgo esnobe e mal educado, mas praticamente desaparece nos volumes seguintes, retornando somente na matinée final de Le Temps retrouvé, sob o pseudônimo de Jacques du Rozier. O leitor toma conhecimento de seu prestígio, mas desconhece os meios pelos quais ele o conquistou. Outro caso surpreendente é o de Monsieur Verdurin. Principal aliado da Patronne na busca incessante pelo reconhecimento, ele desaparece quase que por elipse numa

\footnotetext{
${ }^{1}$ Quincas Borba, p. 761.
} 
rápida menção à sua morte. Substituído rapidamente pelo duque de Duras e, em seguida, pelo príncipe de Guermantes, sua eliminação não causa nenhum dano aos projetos da esposa.

Já Odette e Madame Verdurin, como veremos, têm forte presença no decorrer de toda a obra. Suas trajetórias são acompanhadas e descritas de forma minuciosa pelo narrador. Podemos observar de perto seus salões, seus casamentos, suas visitas, seus gestos, enfim, toda a movimentação social que Ihes possibilita alcançar o faubourg Saint-Germain, tendo saído do pequeno salão da Rua Montalivet. As transformações do caleidoscópio social proustiano se completam sobretudo através das sucessivas mudanças nas situações de tais personagens e seu êxito final, conseguido após percorrerem os numerosos e difíceis degraus rumo ao topo da sociedade francesa.

Ao analisar somente o arrivismo feminino, nosso recorte terá como enfoque as bases específicas sobre as quais o tema se desenvolve. Não podemos considerar as mesmas possibilidades de ascensão para personagens masculinas e femininas, porque as primeiras, na maioria das vezes, podem servir-se de suas profissões, o que, em regra, não ocorre com as mulheres. Camacho, Cristiano, Morel e Bloch, além dos relacionamentos interesseiros, usam o trabalho como trampolim social, ao passo que as alternativas de Guiomar, Helena, Sofia, Odette e Madame Verdurin se resumem praticamente ao casamento e/ou ao sucesso de seus salões.

Vejamos, mais de perto, os contornos dessa constante temática, começando por teorias que a ilustram. 
O tema

\begin{abstract}
"De maneira geral, "a forma é o jorrar das profundezas", como escrevia Jean Rousset. Estaríamos tentados a dizer, jogando com as palavras: jorrar do fundo. Não existe temática a não ser expressa por uma poética, e toda temática é portadora de uma poética virtual. A imaginação, "a rainha das faculdades" segundo Baudelaire, não traz um material temático neutro, mas um material já ordenado conforme os esquemas estruturais que lhe são próprios."

Brunel, Pichois, Rousseau, Que é literatura comparada? ${ }^{2}$
\end{abstract}

A análise dos temas tem expressiva presença nos estudos literários. Devido à natureza de nosso estudo - o empreendimento da leitura simultânea de dois autores de nacionalidades diferentes e, por conseguinte, de culturas distintas -, precisaremos ter em conta dois níveis de exame. Em um primeiro momento serão considerados a articulação e o desenvolvimento do tema em cada um dos textos para que, posteriormente, ele seja visto de forma mais ampla na comparação entre os romances brasileiros e franceses.

Os dois níveis mencionados se referem, na teoria, ao método de análise literária temática com longa tradição na crítica francesa encabeçada, principalmente, pelos trabalhos de Georges Poulet, Gaston Bachelard e JeanPierre Richard e à comparação dos temas no âmbito de mais de uma literatura nacional, sobretudo os trabalhos de Pierre Brunel, Yves Chevrel, Álvaro Manuel Machado e Daniel-Henri Pageux. No primeiro, o crítico geralmente elege um

\footnotetext{
${ }^{2}$ BRUNEL, P. PICHOIS, Cl. ROUSSEAU, A.M. Que é literatura comparada? São Paulo: Editora Perspectiva, 1995, p. 110.
} 
determinado elemento temático considerado central e busca compreender como é constituído, desdobrando-se sobre um único texto, conforme a lição de Jean-Pierre Richard:

"É no espaço da obra, uma de suas unidades de significação: uma dessas categorias da presença reconhecida como sendo particularmente ativa."3

Como tratamos aqui de um aspecto específico comum aos romances selecionados - o arrivismo social -, a apreciação cuidadosa de sua manifestação individual e independente em cada um deles nos parece ser fundamental nessa etapa inicial. Se pensarmos com o teórico Sémir Badir, segundo o qual o termo "tema" poderia ser definido como um conjunto de palavras que se direcionam para uma ideia ${ }^{4}$, ele seria composto por combinações múltiplas de expressões e sentenças que, na sua totalidade, compõem os trechos da obra referentes a ele. Podemos complementar tal reflexão com a formulação de Daniel Bergez, segundo a qual:

"[...] uma leitura temática nunca se apresenta como um levantamento de frequências; ela tende a formar uma rede de associações significativas e recorrentes; não é a insistência que faz sentido, mas o conjunto de conexões que a obra forma, em relação com a consciência que nela se expressa.

\footnotetext{
${ }^{3}$ Trecho de conferência realizada em Veneza por Jean-Pierre Richard, em 1974, citado por Daniel Bergez in BERGEZ, Daniel et alli. Métodos críticos para a análise literária. São Paulo, Martins Fontes, 1997, p. 118.

${ }^{4}$ Para uma compreensão mais completa da concepção e definição de tema ver: BADIR, Sémir. "Qu-est-ce qu'un thème? Une approche sémiologique". Signata 5 (2014). Annales de Sémiotiques.Littérature et sémiotique:histoire et épistémologie. Presses Universitaire de Liège, 2015, pp.19-37.
} 
A partir dessa definição geral, cada crítico orienta sua leitura de acordo com intuições que lhe são próprias (a subjetividade aqui é manifesta), para escolher os temas que comenta. O tema é, com efeito, suscetível de remeter tanto a um conteúdo quanto a uma realidade formal." ${ }^{5}$

Desse modo, interessa-nos examinar como essa escolha temática é construída em forma textual, ou seja, teremos de verificar o modo pelo qual nosso objeto é revelado através das ideias do autor, seu ato de consciência, na sua expressão formal. Por se tratarem de universos singulares, cada romance necessita de uma primeira abordagem que Ihe seja particular e independente, antes de partirmos para o estudo simultâneo dos textos selecionados ${ }^{6}$.

Conforme a procedimento mencionado acima, teremos então, no passo seguinte, o desenvolvimento da abordagem temática considerando também a análise de duas literaturas nacionais distintas com o interesse de que ela nos ajude a expandir e a aprofundar a compreensão do tema selecionado, partindo do enfoque individual e singular para o múltiplo e diversificado. Ou seja, pretendemos debruçar-nos sobre cada um dos romances eleitos de Machado e Proust, para, em um segundo momento, estabelecer pontos de relação mais bem fundamentados. Pensamos aqui com Georges Poulet, que, além de ter contribuído de forma significativa com as teorias de análise temática focadas

\footnotetext{
${ }^{5}$ BERGEZ, Daniel et ali, op. cit., pp. 118, 119.

${ }^{6} \mathrm{Em}$ seu Da literatura comparada à teoria da literatura, A. M. Machado e D.-H. Pageaux apontam a importância de se compreender, num primeiro momento, as obras eleitas de forma independente como premissa para o estudo comparativo, visto que esse exercício "obriga o investigador a empreender duas leituras simultâneas do textos analisados: em primeiro lugar, o texto é, no plano da criação literária, um universo coerente; em segundo lugar, a procura dum sentido deve ser feita no interior do texto e também no conjunto do campo cultural a que esse texto pertence.", Lisboa: Edições 70, 1988, p. 120.
} 
em um único autor ${ }^{7}$, sempre manteve em seu horizonte a importância de se considerar o diálogo entre as diversas literaturas. Vejamos:

\begin{abstract}
"L'importance de la critique thématique devrait être double. Qu'elle dégage et révèle certaines hantises personnelles, points de départs de milles idées ou images rayonnant à partir d'un centre de pensée individuel, rien qui ne nous rende certes à la fois plus poétique et plus intelligible cette pensée. Mais il y a plus. La critique thématique peut encore nous révéler ce qui se transmet d'une pensée à d'autres, ce qui se découvre en diverses pensées comme étant leur principe ou leur fonds commun. Alors, elle tend à se confondre avec cette histoire des idées, des sentiments, des imaginations, qui devrait être toujours adjacente à l'histoire littéraire." 8
\end{abstract}

Quando escolhemos estudar paralelamente $A$ mão e a luva, Helena e Quincas Borba, de Machado de Assis, e os romances de À la recherche $d u$ temps perdu, de Marcel Proust, respaldamo-nos no possível trânsito de ideias sugerido por Poulet. Esse pensamento nos parece pertinente, sobretudo se comparamos literaturas cujas relações são inequívocas, como a brasileira e a francesa, e, mais especificamente, escritores que produziram suas obras em períodos históricos vizinhos ${ }^{9}$. Daí, mais que inferir, podemos constatar certa

\footnotetext{
${ }^{7}$ Talvez sua obra mais relevante, nesse sentido, seja L'espace proustien, publicado em 1963, pelas Éditions Gallimard.

${ }^{8}$ POULET, Georges. Trois essais de mythologie romantique. Saint-Brieuc: Librairie José Corti, 1966, pp. 135, 136.

9 Mais importante que o sincronismo exato do período histórico, as origens e os desdobramentos do tema e suas possibilidades de representações nos diferentes contextos parecem elucidar melhor a questão. Acompanhamos aqui o texto "Les exigences de la dissertation comparatiste" in CLAUDON, Francis. HADDAD-WOTLING, Karen. Précis de littérature comparée. Théories et méthodes de l'approche comparatiste. Paris: Armand Colin, 2004, pp. 38, 39: "Un sujet qui s'applique surtout à des oeuvres modernes peut prendre un éclairage nouveau s'il est rapporté à une conception plus ancienne de la littérature [...] il vaut toujours mieux raisonner sur des idées que sur des dates."
} 
convergência na formação literária de ambos, pois muito provavelmente eles se serviram, para compor suas obras, muitas vezes dos mesmos autores. Se parece evidente ressaltar o profundo conhecimento de Proust em relação à história literária da França, devemos, contudo, assinalar o mesmo no caso de Machado ${ }^{10}$.

No que tange ao nosso objeto, tal observação é crucial, pois algumas personagens da Comédie Humaine, de Honoré de Balzac, em especial Eugène de Rastignac de Le père Goriot, podem ser consideradas paradigmas de figuras arrivistas. Acrescentamos também Julien Sorel de Le rouge et le noir, de Stendhal, como referência importante para tratar do assunto no século XIX na França e nos diversos países receptores dessa cultura. Outra menção fundamental para a compreensão do tópico em Machado são os romances de José de Alencar, pois eles revelam a filiação inegável na tradição francesa somada ao esforço notável de se compor considerando, também, características da especificidade nacional. Desse modo, é possível inferir a relação dupla de Machado com a França através do contato direto com as obras e, também, da experiência de seus antecessores com as mesmas. Acreditamos, portanto, estar diante de um conjunto propício ao exame do

\footnotetext{
${ }^{10}$ Luiz Felipe de Alencastro comenta que a emergência de Napoleão III na França "dá ao Segundo Reinado um novo tom de modernidade e confirma o francesismo das elites brasileiras", ALECASTRO, Luiz Felipe de. NOVAIS, Fernando A. História da vida privada no Brasil Vo. 2. Império: A corte e a modernidade nacional. São Paulo: Companhia das Letras, 1997, p. 43. No mesmo sentido, Gilberto Pinheiro Passos ressalta que "a variada gama de contribuições francesas, no campo da literatura, filosofia, moda, ou mesmo tecnologia, deixa claro que a representação do Brasil não se poderia fazer sem a inclusão de tal marca estrangeira", O Napoleão de Botafogo: presença francesa em Quincas Borba de Machado de Assis. São Paulo: Annablume, 2000, p. 11.
} 
arrivismo, já que, além do tema ser um índice comum às obras ${ }^{11}$, constatamos ainda a presença de uma base literária significativa familiar aos dois escritores.

Outro fator relevante para esta análise é a natureza do assunto. No caso do tema do arrivismo, não se pode prescindir do contexto histórico, pois a compreensão do fenômeno na esfera social é a matéria basilar da qual o escritor se serve para construir sua ficção. Ressaltamos não se tratar de uma transcrição ou de um reflexo dos eventos histórico-sociais para a literatura, mas de um ponto de partida na constituição de um corpus artístico, cujos relatos das relações sociais, considerando-se a época e a conjuntura em que foram escritos, são perfeitamente verossímeis. Além disso, esses textos estão ambientados em tempos históricos precisamente definidos, sendo os de Machado no Segundo Reinado e os de Proust na Belle Époque e no período imediatamente anterior a ela.

A apresentação do termo "arrivismo", por si só, nos mostra a impossibilidade de se ignorarem, nesse esforço analítico inicial, os vínculos socioeconômicos e comportamentais referentes aos recortes temporais do Brasil e da França. Expressão difícil de ser definida ou conceituada com exatidão, originária do verbo arriver - "chegar" - em língua francesa, passa a ser usada para descrever o processo de ascensão social possibilitado pela Revolução de 1789 e também pela trajetória paradigmática de Napoleão. O termo, presente em análises literárias feitas a partir da metade do século XIX,

\footnotetext{
${ }^{11}$ BERGEZ, Daniel et alli, op. cit., p. 99. Segundo Bergez, "o tema fornece um elemento comum de significação ou de inspiração, que permite comparar, a partir de um mesmo índice, obras de autores diferentes"
} 
torna-se sinônimo de ambição e de vontade de fazer parte de um universo que está acima daquele em que a personagem se encontra.

Há definições dos termos arrivisme e arriviste na Encyclopédie Universelle e no dicionário da Académie Française, datadas de 1893 e 1934, respectivamente. $^{12}$ Seguiram-se muitas outras em diversas edições dos dicionários Larousse, Le Petit Robert, entre outros, sendo notável a frequência de exemplos de trechos de personagens emblemáticas: o já mencionado Eugène de Rastignac de Le père Goriot (1835), de Balzac, e Georges Duroy de Bel Ami (1885), de Maupassant. Nas obras de referência citadas acima, as definições dos termos variam e se verificam diferenças entre elas. Se, na Encyclopédie Universelle, encontramos uma definição mais incisiva: arriviste: personne dénuée de scrupules qui veut arriver, réussir dans le monde par n'importe quel moyen ${ }^{13}$, nos dicionários etimológicos inglês e brasileiro observamos descrições mais brandas: arriviste: the notion is of a person intent on "arriving" at success or in society ${ }^{14}$ e "arrivismo: procedimento de quem quer vencer na vida de qualquer modo". ${ }^{15}$

Nesse sentido, será de grande importância diferençar os traços de arrivismo e suas gradações em cada uma das personagens que propusemos analisar. Madame Verdurin, Odette Swann, Gilberte Swann (como continuação de Odette) e Sofia Palha são figuras em que o dado arrivista aparece de forma

\footnotetext{
12 http://encyclopedie universelle.fracademic.com/26439/arriviste. Data de consulta: 15/07/2015.

13 Idem

${ }^{14}$ http://www.etymonline.com/index.php?term=arriviste. Data de consulta: 15/07/2015.

${ }^{15}$ CUNHA, Antônio Geraldo da. Dicionário Etimológico da Língua Portuguesa. Rio de Janeiro: Nova Fronteira, 1982, p. 71.
} 
evidente. Guiomar e Helena poderiam exemplificar a definição do dicionário etimológico inglês, já que há exemplos textuais de seus esforços para se adequarem ao novo meio em que se inserem. Mais adiante, vamos nos deter nessas nuances, mas, antes disso, faz-se necessária uma contextualização histórico-social dos ambientes nos quais as narrativas se passam.

Todas as acepções indicam o empenho, em menor ou maior grau, do indivíduo que pretende mudar sua posição em determinado meio, buscando a mobilidade social. Ora, esse movimento começa a ser tratado com mais frequência na literatura, a partir do percurso exemplar de Napoleão, porque desse momento em diante, apesar de incomum, a ascensão se torna possível. Vemos, em Le rouge et le noir e em Le père Goriot, uma brecha que se abre para que personagens como Julien Sorel e Rastignac se insiram na elite. Apesar das grandes diferenças, a possibilidade de mudança advém, no Brasil e na França, da mescla crescente entre as classes, sendo a sociedade francesa muito mais hierarquizada e regulada que a nossa. Para uma melhor compreensão dos modos pelos quais esse trânsito ocorre, façamos uma breve incursão nesses momentos históricos de ambos os países. 


\section{O Segundo Reinado e a Belle Époque}

O Brasil do Segundo Reinado, representado nos três romances machadianos, experimentava sobretudo no Rio de Janeiro - capital do Império - decisiva etapa de consolidação da vida social por meio de reuniões, saraus, bailes e teatro. ${ }^{16}$ Embora a primazia da vida familiar tenha prevalecido ainda por várias décadas, os eventos recreativos tornavam-se cada vez mais frequentes e regulares. Desse modo, de acordo com a historiadora Maria Ângela D'Incao, há a simultaneidade de uma convivência baseada na intimidade familiar e ocasionais reuniões com os convivas mais próximos. Vejamos:

"Essa interiorização da vida doméstica, no entanto, deuse ao mesmo tempo em que as casas mais ricas se abriam para uma espécie de apreciação pública por parte de um círculo restrito de familiares, parentes e amigos. As salas de visita e os salões - espaços intermediários entre o lar e a rua eram abertos de tempos em tempos para a realização de saraus noturnos, jantares e festas." 17

Com isso, as regras de convívio social se tornam mais complexas. A possibilidade de relacionar-se com pessoas que não pertencem à família favorece trocas diversas, sociais e econômicas. Veremos, mais adiante, que tal dinâmica será fundamental para a ascensão de Guiomar, Helena e Sofia.

\footnotetext{
${ }^{16}$ PINHO, Wanderley. Salões e damas do Segundo Reinado. Livraria Martins, 1970, p. 105: "A primeira época social do reinado, que poderíamos, um tanto arbitrariamente, limitar de 1840 a 1860 - e mesmo prolongar até 1867 ou à guerra do Paraguai, houve certo trecho em que a sociedade se tomou da febre das reuniões, dos bailes, dos concertos, das festas."

${ }^{17}$ D'INCAO, Maria Ângela. "Mulher e família burguesa" in PRIORE, Mary del. (org.) História das mulheres no Brasil. São Paulo: Editora Contexto, 2000, p. 228.
} 
Roberto Schwarz mostra que esse é um procedimento no qual todos saem ganhando, o carreirista atingindo seu objetivo e a família preenchendo determinado vazio com alguém de talento. ${ }^{18}$

A elite fluminense, formada principalmente por proprietários de terras, comerciantes e um crescente número de industriais e negociantes atrelados ao mercado financeiro ${ }^{19}$, possuía certa homogeneidade. Era um público interessado em alinhar-se com as novidades vindas da França, especialmente a partir do estabelecimento do Segundo Império (1852-70) nesse país. Chegavam de lá frequentemente revistas de moda, folhetins, operetas e romances. Logo em seguida, passava a ser distribuído no Rio de Janeiro o Jornal das Famílias; a publicação, editada pelo francês Garnier, apresentava um misto de gravuras e tendências francesas, além de contos e romances brasileiros, muitos de Machado de Assis. ${ }^{20}$ Assim, essa fatia privilegiada da sociedade fluminense vai construindo seu modo de viver e de divertir-se, passando a ser referência de comportamento e de cultura. Para conseguir adentrá-la, nossas personagens não medirão esforços. O empenho para dominar tais códigos de conduta será imprescindível.

\footnotetext{
${ }^{18}$ SCHWARZ. Roberto. Ao vencedor as batatas. São Paulo: Duas Cidades/ Editora 34, 2000. p. 89 : " [...] a família, de preferência abastada, é a intocável depositária da ordem e do sentido da vida. Oposta ao egoísmo do celibato e ao desperdício da viuvez, à esterilidade das relações passageiras e à brutalidade das relações desiguais, à irregularidade em geral, à obscuridade da pobreza, à aridez do trabalho, e a outras mais desgraças do país, a vida familiar é a esfera reparadora em que as disparidades sócias e naturais devem achar consolo e sublimação."

19 IGLÉSIAS, Francisco et Al. História geral da civilização brasileira; t.2; vol. 5. O Brasil Monárquico: Reações e transações. Direção e introdução geral de Sérgio Buarque de Holanda. Rio de Janeiro: Editora Bertrand Brasil, 1997, p. 353.

${ }^{20}$ ALENCASTRO, Luiz Felipe de. "Vida privada e ordem privada no Império", op. cit.,pp. 43, 44.
} 
É importante ressaltar que a distância entre as camadas mais altas e as médias era pequena, visto que podiam morar, muitas vezes, no mesmo bairro. Por isso, em Machado, os movimentos de transição das figuras são suaves e não provocam quase nenhuma mudança nos hábitos daquele grupo, ou seja, não há transformação social significativa. Dentro de um cenário político e socioeconômico estável, a família mantém sua função centralizadora ${ }^{21}$. Não podemos deixar de mencionar que isso ocorre, em parte, por causa da estrutura da cidade, não tendo esta alcançado ainda uma urbanização plena. As grandes propriedades descritas nas obras de Machado guardam características típicas de residências rurais devido às suas dimensões. A maioria delas mantém escravos como sua principal força de trabalho, de modo que a família funciona como um organismo quase independente, fechado e voltado para si mesmo. Tal configuração espacial será determinante na compreensão da área de atuação das personagens a ser detalhada posteriormente. Nesse sentido, o Rio de Janeiro permanece bastante provinciano, apesar das transformações mencionadas. Veremos que as possibilidades de deslocamento serão restritas à limitação do espaço nas narrativas.

No entanto, a partir de 1850, a vida econômica ganha maior relevo e alguns capitalistas urbanos (caso do barão de Mauá) buscam modernizar

\footnotetext{
${ }^{21}$ SCHWARZ, Roberto, op. cit., p. 89: "Agente civilizador, ou refúgio dos civilizados, é ela o critério da moralidade e da racionalidade das ações humanas, e seus desencontros - que são dificuldades, mas não problemas - formam o centro reflexivo desses livros, confinados quase inteiramente ao seu círculo."
} 
transportes, comércio e introduzir uma incipiente indústria ${ }^{22}$. As transformações econômicas e sociais decorrentes dessas iniciativas fazem com que as relações pessoais e profissionais se tornem mais dinâmicas nos anos $1860 .^{23}$ Tais mudanças não passarão despercebidas de Machado de Assis, que glosará ficcionalmente a nova conjuntura em Quincas Borba, cuja trama se passa entre 1867 e 1871.

Passemos agora ao contexto histórico da França a partir do qual o conjunto dos textos de À la recherche du temps perdu é elaborado. No período que vai aproximadamente de 1879 a 1919, temos um universo completamente diferente do brasileiro. O país, naquele momento, era um dos mais ricos e influentes em termos econômicos e culturais. A sequência das monumentais Exposições Universais, realizadas a partir dos anos 1850, afirma o prestígio e a posição importante ocupada pela nação no mundo ocidental. A França constituía uma das referências principais tanto para o restante da Europa quanto para as Américas. Da política à literatura e ao comportamento, seu grande alcance era inquestionável. Essa posição de centralidade, contudo, não

\footnotetext{
${ }^{22}$ A esse respeito ver CALDEIRA, Jorge. Mauá. Empresário de Império. São Paulo: Companhia das Letras, 1996.

${ }^{23}$ IGLÉSIAS, Francisco et Al., op. cit., pp. 353, 354: "No decênio posterior a 1850, segundo mostra Caio Prado Júnior, fundam-se '62 empresas industriais, 14 bancos, 3 caixas econômicas, 20 companhias de navegação a vapor, 23 de seguros, 4 de colonização, 8 de mineração, 3 de transporte urbano, 2 de gás e, finalmente, 8 estradas de ferro'. Começa a configurar-se uma estrutura econômica diferenciada.[...] É óbvio que esse desenvolvimento econômico ocasiona a progressiva diferenciação das ocupações e das relações sociais." Também João Cruz Costa, citado por John Gledson em seu Machado de Assis. Ficção e história, p. 77, comenta o "notável progresso econômico que se expressa, no Brasil, a partir de 1860, numa sensível ascensão de padrão de vida de certas classes da população e na incipiente aparelhagem técnica do País, tal como estradas de ferro, mecanização das indústrias rurais, instalação das suas primeiras manufaturas."
} 
refletia homogeneidade na organização social. Ao contrário, os conflitos e contradições internos se afiguravam grandes, e as adaptações necessárias decorrentes das inúmeras reviravoltas políticas desde 1789 ainda se faziam sentir na virada do século XIX para o XX. Nos núcleos criados por Proust, em À la recherche du temps perdu, os atritos entre as personagens e as adequações das mesmas aos grupos aos quais pretendem pertencer ocuparão uma parte considerável da narrativa. Vejamos então quais os fatores que desencadearam essa situação peculiar.

Em um país cuja tradição das famílias nobres data de muitos séculos, sua ascendência sobre o imaginário do povo perdura também por um período extenso, a despeito das grandes mudanças estruturais ocorridas. Sabemos que esse tipo de transição de pensamento e de comportamento não se consolida rapidamente, de modo que há sempre uma intersecção entre o que estava estabelecido antes e o que prevalecerá depois. No caso dessa sociedade, acompanhamos a lenta perda de espaço e de influência da alta nobreza para a burguesia que, há muito - tal situação já existia nos séculos XVII e XVIII ${ }^{24}-$, vinha demonstrando todo o seu poder. Ambos os grupos precisaram ajustar-se aos novos tempos; o primeiro sendo obrigado a abrir espaço para o segundo e este se esforçando para dominar os códigos principais daquele. ${ }^{25}$ Se a

\footnotetext{
${ }^{24}$ BIDOU-ZACHARIASEN, Catherine. Proust sociologue. De la maison aristocratique au salon bourgeois. Paris: Descartes et Cie, 1997, p. 50: "La prise en considération de la valeur individuelle d'une personne par rapport à sa valeur sociale n'était pas un phénomène nouveau. Les philosophes des Lumières introduits dans certains salons aristocratiques un siècle auparavant en étaient l'illustration."

${ }^{25}$ WINOCK, Michel. La Belle Époque. La France de 1900 à 1914. Perrin, 2002, p. 110: "L'aristocratie nobiliaire qui dominait encore la société sous la Restauration, ne garde son pouvoir et son rang qu'à l'interieur d'une grande bourgeoisie. Cette ancienne aristocratie a
} 
aristocracia ainda mantinha seu prestígio, ela só podia exercê-lo apoiada no poder material da classe ascendente. A esse respeito, o historiador Serge Pacaud comenta:

"L'ancienne noblesse capétienne et les Bourbons après celle de l'Empire devaient accepter un autre phénomène indubitable à leur classe et admettre que la haute société se faisait phagocyter par des parvenus qui possédaient entre leurs mains les leviers du pouvoir, du commerce et de l'industrie. Bien que les familles nobles les plus illustres, issues du temps de croisades, furent rétives à l'admettre, il fallut prudemment se pousser un peu pour partager le gâteau de la Nation. On se mélangea avec réticence, les bonnes manières n'étaient pas innées, mais, le temps passant, chacun put constater où était son intérêt." ${ }^{26}$

Temos, então, dois grandes conjuntos que passam a ser cada vez mais interdependentes. O aristocrático detém o peso da tradição, os títulos e os preceitos formais de gosto e conduta, ao passo que o burguês possui o dinheiro e o poder político necessários à manutenção da engrenagem social. Tal conjuntura tornará as alianças políticas, econômicas e matrimoniais inevitáveis. As altas aspirações dos burgueses farão com que passem a mimetizar certos costumes da elite nobiliária ao mesmo tempo em que confirmam sua relevância, exigindo para si o tão almejado reconhecimento como parte fundamental nesse sistema, em certo sentido, "integrado". ${ }^{27}$ Dessa maneira, não é possível imaginarmos que acordos de tal ordem se deem com muita tranquilidade para nenhuma das partes. A alta aristocracia não tem outra

gardé des préjugés, des souvenirs, et peut encore imposer un certain snobisme à la vie mondaine $[\ldots] "$

${ }^{26}$ PACAUD, Serge. Vie Quotidienne des Français à la Belle Époque. Paris: CPE, 2008, p. 8.

${ }^{27}$ Ibidem, p. 11. 
opção, mas o faz a contragosto; a elite burguesa, por outro lado, quer ser aceita, mas não subjugada. Não há como escapar de uma convivência muitas vezes conflitante, de posturas opostas e partidos tomados até que a linha divisória se torne cada vez mais tênue e a assimilação mútua se complete.

Para compreender mais amplamente o contexto, não podemos deixar de mencionar também o "Affaire Dreyfus". O caso do capitão, condenado por traição em 1894, revela não só o antissemitismo no país, como também expõe os pensamentos e anseios de cada setor da população. A aristocracia, de modo geral, posiciona-se contra o militar, mais pelo sentimento nacionalista em relação ao exército que pelos fatos em si, em uma tentativa de manter por mais tempo a relevância da origem francesa. Os burgueses, sem nome ou títulos, identificados, portanto, com Dreyfus, tendem a apoiar a revisão do processo e a comprovação de sua inocência. Tais fatos serão explorados por Proust de forma minuciosa, revelando os interesses reais de cada personagem ao assumir uma ou outra posição em relação ao episódio. Não obstante, veremos no romance dreyfusistas e antidreyfusistas partilharem o mesmo ambiente sem prejuízos, conforme as conveniências. A tomada de partido aqui demonstra mais uma postura social e intelectual, não limitando o convívio entre figuras com ideologias opostas, já que muitas vezes essas relações eram interessantes e úteis a ambas. No trecho a seguir, Claude-Isabelle Brelot expõe um pouco do que vinha a ser o cenário à época:

"Ce sont "l'honneur de l'armée", et non le sien, et la force de la chose jugée par la magistrature qui mobilisent ces gentilshommes et ces femmes du monde que l'échec d'une Restauration a inévocablement éloignés des sphères dirigeantes. Reste que la noblesse bénéficie en 1894 d'une 
insertion sociale largement diversifiée, bien au-délà du bastion reconquis de l'armée et du bastion perdu de la magistrature: elle est portée par un fort mouvement d'adaptation à la société post-révolutionnaire et ses salons, pour être le fleuron d'une "culture d'ordre", demeurent ouverts à la fusion des elites dans l'excellence." 28

A diversificação da ocupação do espaço da elite acentua-se gradativamente devido à força crescente dos ideais republicanos ${ }^{29}$. A primeira tendência da alta nobreza de condenar Dreyfus em nome do retorno de uma França católica e moral, lutando contra seus inimigos internos, dissipa-se até desaparecer por completo $^{30}$. O nacionalismo exacerbado cede lugar ao cosmopolitismo, fazendo com que as mentalidades arraigadas se ajustem e grandes famílias históricas se aliem a detentores dos meios financeiros. A consequência inevitável dessa operação é a assimilação de novos pensamentos, políticos e artísticos. Desse modo, a tradição que outrora ocupava soberana a função de estabelecer as regras de convivência social se vê obrigada a dividir o posto com o que havia de mais inovador. Como as relações cotidianas tinham nos salões seus principais espaços de atuação, os antigos, fechados para poucos, perdem prestígio político e intelectual, enquanto os mais alinhados com as renovações culturais viram referência atingindo seu ápice nos anos da Primeira Grande Guerra (1914-1918). O novo panorama se resume, nas palavras de Brelot, assim:

\footnotetext{
${ }^{28}$ BRELOT, Claude-Isabelle. "Entre nationalisme et cosmopolitisme: les engagements multiples de la noblesse" in BIRNBAUM, Pierre (dir.). La France de l'Affaire Dreyfus. Paris: Gallimard, 1994, p. 344.

${ }^{29}$ Sabemos que, apesar de a III República da França ter começado havia algum tempo, em 1870, uma parcela aristocrática poderosa ainda clamava pelos valores monárquicos.

${ }^{30}$ BRELOT, Claude-Isabelle, op. cit., p. 21.
} 
"Au nom de l'excellence artistique et littéraire, quelques salons réactivent la fusion des valeurs entre politiciens républicains, intellectuels dreyfusards et hommes et femmes du monde." 31

Os salões e as mulheres

"Un salon, c'est d'abord une femme. Et, de préférence, une femme qui a de l'esprit." ${ }^{32}$

Observaremos mais adiante, na análise textual dos romances de Machado e Proust, a conhecida importância dos salões como espaço principal das relações sociais. ${ }^{33}$ As residências, muito mais que espaços privados destinados à habitação, consolidam-se como o local onde se realizam negócios, discute-se política, vivencia-se a arte e concretizamse acordos matrimoniais. Servem tanto à esfera da vida pública das famílias quanto à privada. Importantes na vida familiar, as casas são identificadas especialmente com as mulheres. Como o homem, tanto no Brasil quanto na França, gozam de uma liberdade muito maior para transitar por diversos meios, cabe à mulher, presença mais constante na

\footnotetext{
${ }^{31}$ Op. cit., p. 353.

${ }^{32}$ MARTIN-FUGIER, Anne. Les salons de la Ille République - Art, littérature, politique. Perrin, 2003 et 2009 pour la presente édition, p. 8.

${ }^{33}$ Vamos nos ater aos salões, pois são ambientadas neles as cenas selecionadas para este estudo. Mas havia outros espaços essencialmente sociais: clubes (no caso de Swann), restaurantes da moda, teatros e outros.
} 
morada, a responsabilidade de organizar sua dinâmica de funcionamento.

No nosso país, em meados da segunda metade do século XIX, vimos que, apesar do crescente aumento de atividades adequadas à participação feminina, esta ainda ocorria predominantemente nos domínios domésticos. Dada a extrema relevância do lar, as camadas elevadas da sociedade ansiavam por habitar propriedades as mais imponentes possíveis, pois ocorreria ali grande parte da sociabilidade do grupo. A esse respeito Maria Ângela D'Incao comenta:

"Nas casas, domínios privados e públicos estavam presentes. Nos públicos, como as salas de jantar e os salões, lugar das máscaras sociais, impunham-se as regras para bemreceber e bem-representar diante das visitas. As salas abriamse frequentemente para reuniões mais fechadas ou saraus, em que se liam trechos de poesias e romances em voz alta, ou uma voz acompanhava os sons do piano ou harpa." ${ }^{34}$

Esse sistema obrigava e favorecia, a um só tempo, a necessidade de se educarem essas mulheres, já que passariam a ser observadas e avaliadas pela opinião dos que com elas conviviam. As poucas que tinham o privilégio de serem polidas tinham aulas em casa ou, mais raramente, em escolas católicas, nas quais aprendiam fundamentalmente línguas e música. ${ }^{35}$

\footnotetext{
${ }^{34}$ D'INCAO. Maria Ângela, op. cit., p. 228.

${ }^{35} \mathrm{Em}$ uma carta de 1873, Herbert H. Smith chama a atenção para o pequeno número de mulheres educadas adequadamente: "Aqui, como em toda a parte, existe todo tipo de gente para formar a comunidade. Apenas, no Brasil, a proporção de famílias realmente boas, finas, educadas é muito menor que nos Estados Unidos: pequena demais, até agora, para exercer
} 
Em tal contexto, o papel da mulher como vitrine da família torna-se cada vez mais importante. Como o objetivo maior de quase todas era um bom casamento, elas se empenhavam para que tal aliança alcançasse o maior êxito possível. Constantemente observadas e julgadas por aqueles que as rodeavam, elas tomavam para si a função de serem exemplares e também capazes de alavancar o apreço público do casal, conforme aponta D’Incao:

\begin{abstract}
"Da esposa do rico comerciante ou do profissional liberal, do grande proprietário investidor ou do alto funcionário do governo, das mulheres passa a depender também o sucesso da família, quer em manter o elevado nível e prestígio sociais já existentes, quer em empurrar o status do grupo familiar mais e mais para cima." ${ }^{36}$
\end{abstract}

De certa forma, a presença feminina possibilitava a manutenção da rede de contatos necessária ao percurso ascensional ambicionado pelo conjunto

muita influência no país. Quando se encontram essas famílias, verifica-se a existência de uma vida social muito próxima da que estamos acostumados, em casa; maneiras delicadas, conversas inteligentes e um verdadeiro respeito por toda senhora de condição. As senhoras são espirituosas, vivas, brilhantes.", LEITE, Miriam Moreira. A condição feminina no Rio de Janeiro no século XIX. São Paulo - Brasília: Editora HUCITEC - INL, Fundação Nacional PróMemória, 1984. p. 77. Nesse mesmo livro, temos dois trechos de cartas que revelam um pouco da educação das mulheres. Na primeira, de J. B. Debret, tomamos conhecimento que, já em 1816, alguns conhecimentos eram então apreciados: "Os dotes mais apreciados na sociedade são os da dança e do canto, porque permitiam brilhar nas reuniões. Na alta sociedade exige-se também música, principalmente piano, bem como o conhecimento das línguas francesa e inglesa e de desenho." p. 70. Na segunda, escrita em 1825 por E. Belman, tais afirmações também se confirmam: "No Brasil, a moça bem educada, de boa formação (uma moça muito prendada) é aquela que com um pouco de música e de francês, sabe dançar um solo inglês, sabe bordar, fazer crochê e conhece a difícil arte de descascar, com gosto, uma laranja." pp. $70,71$.

${ }^{36}$ Op. cit., p. 229. 
familiar. ${ }^{37}$ Ao tratar de política e de economia, os homens se utilizavam dessas festas e jantares como forma discreta e elegante de travar negócios e de aproximar-se de pessoas de seu interesse. O círculo de amizades certamente não era desinteressado, de maneira que os convivas eram afastados ou aproximados, de acordo com a necessidade e a conveniência de dado momento. Tais vicissitudes eram, naturalmente, traduzidas no contexto social pelas mulheres ao convidar ou excluir determinada figura, ao acercar-se de algum nome de peso ou ignorar aqueles cuja companhia já não traz nenhuma vantagem. Portanto, nas palavras de Maria Ângela D'Incao, essas mulheres "significavam um capital simbólico importante, embora a autoridade familiar se mantivesse em mãos masculinas". ${ }^{38}$ Mais que mães e donas de casa, elas desempenhavam papel determinante para a conquista de uma imagem favorável, especialmente numa cidade semiurbana e dependente de compadrios, como era o Rio de Janeiro àquele tempo.

Vejamos agora quais eram os elementos do cenário francês. Paris e a província viviam um momento extremamente favorável às sociabilidades no período denominado Belle Époque. Apesar da derrota na guerra francoprussiana, a nação desfrutava de um crescimento econômico consistente, a camada burguesa ganhava cada vez mais espaço no topo social e as artes

\footnotetext{
${ }^{37}$ A esse respeito Ingrid Stein comenta: "Com a urbanização, exigia-se da mulher, sobretudo na Corte, que ela soubesse receber as visitas do marido e representá-lo publicamente. Além disso à mulher atribuía-se a tarefa de colaboradora e incentivadora do homem, ela devia estimulá-lo à conquista de êxitos. Ao homem ficavam destinadas as atividades fora do âmbito caseiro - contatos da vida pública, comercial, política e cultural - , enquanto à mulher as estritamente ligadas à casa. A eventual extrapolação deste limite só podia se dar através do marido, do incentivo a ele e da colaboração em suas atividades.", em seu Figuras femininas em Machado de Assis. Rio de Janeiro: Paz e Terra, 1984, p.23.

${ }^{38}$ D'INCAO, op. cit., pp. 229, 230.
} 
encontravam terreno propício para um desenvolvimento excepcional. ${ }^{39}$ Grandes nomes da música, da pintura, do teatro e da literatura surgiam naquele contexto. Diferentemente do Rio de Janeiro sob Pedro II, o modus vivendi ali era predominantemente urbano, tendo a cidade sido completamente transformada com os trabalhos monumentais do Barão Haussmann. A proliferação de salões de todos os tipos proporcionava uma atmosfera efervescente à capital. Sabemos que o hábito aristocrático de receber vinha de longa data, entretanto, a profusão de tal costume na fatia emergente da sociedade era considerável. Se pensarmos com o historiador Michel Winock, podemos deduzir que o fenômeno decorre do aumento do poder aquisitivo desses indivíduos:

\begin{abstract}
"Tous les bourgeois, y compris ceux qui travaillent, ont des revenus patrimoniaux, d'importance variable, qui permettent encore à certains l'oisiveté. Ce sont ces riches oisifs bourgeois et notables - qui donnent son éclat à la vie mondaine de la Belle Époque.[...] À la Belle Époque, un grand homme d'affaires parisien est propriétaire d'un hôtel particulier, de plusieurs immeubles de rapport à Paris, d'un ou plusieurs châteaux en province, de villas de plaisance en Normandie ou à Nice." 40
\end{abstract}

A vontade de incluir-se no rol privilegiado de atrações da cidade tem sua realização mais plena na consolidação de um salão. Apesar das características evidentes que diferenciam esse universo do brasileiro, a mulher desempenha na França também papel central e fundamental nesses eventos rotineiros. ${ }^{41}$ Do

\footnotetext{
${ }^{39}$ WINOCK, Michel, op. cit., pp. 72-82.

${ }^{40}$ Op. cit., pp. $117,118$.

41 MARTIN-FUGIER, Anne, op. cit., pp. 122, 123: "Il revenait à une femme d'assurer la sociabilité, les relations avec la famille proche et lointaine, les amis et les connaissances. Elle
} 
estilo - literário, político ou musical - ao grupo de convidados, cabe a ela conceber, projetar e edificar o ambiente das reuniões e das festas. Abordaremos nos próximos capítulos a importância enorme que Madame Verdurin e Odette Swann dão à construção de seus espaços de recepção. Se as grandes damas da nobreza, a exemplo da princesa e da duquesa de Guermantes, dominam a arte de receber desde sempre, as novas candidatas se veem compelidas a aprendê-lo, dando um passo de cada vez. Para tanto, as que não tiveram o privilégio do berço irão percorrer o extenso caminho de aquisição de modos, cultura e, por fim, notoriedade.

Segundo Anne Martin-Fugier, entre meados de 1880 e 1914, todas as grandes senhoras, fidalgas e burguesas, tinham o seu dia, ou seja, cada uma escolhia um dia fixo da semana no qual recebiam para comer, ouvir música e principalmente conversar, arte primordial de convívio àquele tempo. Nesse mesmo texto, a autora resgata alguns comentários bastante ilustrativos do jornalista e escritor Émile Henriot acerca do assunto:

"Selon Émile Henriot, il y a quatre conditions pour qu'existe un salon littéraire: que la maîtresse de maison prenne un 'jour', qu'elle affiche une spécialité - le thé, le porto, la pâtisserie... - qu'elle sache causer et, plus encore, donner à causer, et enfin qu'elle reçoive parfois la visite d'un grand homme: 'S'il $a$, de fondation, un académicien, voire son membre de l'Académie des Inscriptions et Belles Lettres, c'est

écrivait les lettres nécessaires dans toutes les ocasions de la vie - des voeux de bonheur pour un mariage jusqu'aux condoléances en passant par les souhaits du nouvel an - ellle rendait les visites adéquates, elle recevait les collègues de son mari. Les activités de celui-ci déterminaient souvent les fréquentations de la famille, mais la maîtresse de maison pouvait apporter une touche personnelle importante." 
parfait. Mais, l'attraction, l'invité de choix: voilà la fortune d'un salon."' 42

A descrição acima do que vinha a ser um salão literário pode servir igualmente para os que tinham como atração as artes plásticas ou a música, oferecendo ao público pintores, compositores ou intérpretes, consagrados ou em ascensão. Notemos que a anfitriã, além da responsabilidade de ser ela mesma divertida e interessante, atua como maestrina na condução da noite, regendo convidados e o programa proposto para aquele dia, organizando a conversação, alternando, de forma apropriada, a posse da palavra de um para outro. Mesmo que as conexões do marido definissem em parte quem frequentava a casa, era a mulher que se encarregava de conquistar e manter o círculo de convivas.

Os salões aristocráticos extremamente fechados, restritos a poucas pessoas, vão perdendo espaço para os burgueses, pois estes são mais abertos e variados. Aqueles, calcados na tradição familiar não se abrem às novidades e raramente aceitam, com exceção de alguns artistas de interesse, a visita de quem não é seu par. Os novos, muito mais ecléticos, anseiam por novidades, daí o grande espaço ocupado pelas artes. Notemos, no entanto, que a partir de 1900, as distinções entre eles vão se empalidecendo e a assimilação dos dois será inevitável. Os burgueses da camada mais alta, já absorvidos pela nobreza, passam a considerar-se como iguais a ela, adotando alguns de seus hábitos e diferenciando-se propositalmente daqueles que não tiveram a mesma oportunidade. Por outro lado, a elite aristocrática não tem alternativa; vê-se

\footnotetext{
${ }^{42}$ Op. cit., p. 159.
} 
compelida a associar-se a eles, deixando para trás os resquícios da Restauração.

Dos contextos expostos acima vão partir Machado de Assis e Marcel Proust para a composição de suas obras. Reiteramos que a obra literária não é reflexo do chão cultural, mas, nesses casos, se servem dele de modo criativo e singular. Interessa-nos, neste estudo, como tais textos foram formados, ou seja, o modo pelo qual o pensamento das épocas em questão, brevemente abordado neste capítulo, foi ponto de partida para a construção de escrituras ficcionais e artísticas. Para tanto, vamos debruçar-nos, a partir de agora, na leitura e análise detalhadas dos romances. 


\section{Capítulo II}

\section{Primeiros passos}

Qu'est-ce qu'un arriviste? Un futur arrivé.

Jules Renard, Journal 1887/1910 ${ }^{43}$

Origens obscuras

Os processos de ascensão representados nos romances eleitos são ancorados linearmente no tempo das narrativas. Eles podem desenvolver-se em um período mais curto ou mais longo, mas, em todos os casos, há uma trajetória cuja característica principal é a progressão contínua das personagens. Nossas cinco figuras, Guiomar, Helena, Sofia, Odette e Madame Verdurin, são contextualizadas em etapas gradativas de evolução social. Fazse necessário analisar cuidadosamente cada percurso para se ter um melhor entendimento de suas particularidades, pois enquanto os enredos machadianos são ficcionalizados em, no máximo, cinco anos, o de Proust se estende por aproximadamente quatro décadas.

Para facilitar a organização deste estudo, optamos por dividir a abordagem do tema em três fases: uma inicial, a ser desenvolvida neste

\footnotetext{
${ }^{43}$ A citação de Jules Renard consta no seu Journal de 1887/1910 e o trecho acima está disponível nesta biblioteca digital: http://www.ibibliotheque.fr/journal-1887-1910-jules-renardren journal/lecture-integrale/page284. Data de consulta: 20/10/2015.
} 
capítulo, cujo objetivo será identificar os dados antecedentes que já indicariam uma inclinação das personagens ao arrivismo; outra intermediária, na qual procuraremos assinalar os principais pontos da fase de transição do meio anterior ao seguinte; e, por fim, a consolidação plena na nova posição que tanto se empenharam para ocupar.

No caso das heroínas de Machado, percebemos um padrão em A mão e a luva e Helena e uma variação dele em Quincas Borba. Para compor Guiomar e Helena, o narrador resgata a infância com o intuito de comprovar os gérmens das virtudes que possuem, as quais serão desenvolvidas por completo até o fim do texto. Já o retrato de Sofia é construído a partir do início da vida adulta, mais precisamente quando se casa com Cristiano Palha e é a única que acompanharemos até os trinta anos de idade, pois, nos desfechos das outras duas obras, Guiomar e Helena não chegam sequer aos vinte. Ainda assim, observaremos também naquela o mesmo procedimento de que lança mão o narrador: a adequação gradual ao novo meio a que deseja pertencer.

Já neste momento, gostaríamos de defender a presença de Helena junto às outras, concordando com Lúcia Miguel Pereira segundo quem "Helena aproveita-se de um equívoco para subir de nível social” ${ }^{44}$.Ora, vimos no capítulo anterior que o arrivismo pode ter, e geralmente tem, diferentes graus de ambição e motivação, sendo os esforços proporcionais a eles. Cada romance revela uma intensidade particular nesse aspecto, sendo mais explícito em $A$ mão e a luva e Quincas Borba e velado e discreto em Helena. No entanto, o desfecho, no qual predominam o arrependimento e a redenção, não

\footnotetext{
${ }^{44}$ PEREIRA, Lúcia Miguel. Machado de Assis. Estudo crítico e biográfico. Editora Itatiaia Limitada, Edusp, 1998, p. 156.
} 
é suficiente para apagar toda a trajetória de empenho deliberado para fazer parte de uma esfera privilegiada. Se fosse esse o caso, a contrição final de Julien Sorel, em Le rouge et le noir, invalidaria as longas páginas de seu esforço incansável para romper naquele meio. Helena e Julien Sorel não são representantes do percurso completo e bem-sucedido de ascensão como Guiomar, Sofia e Rastignac, figura arrivista modelar de Balzac, mas escalam os degraus que os levariam ao topo.

Reconhecemos que a vontade de pertencer ao novo círculo, no qual Helena se vê inserida, pode ser vista de forma ambígua, pois ela tem o álibi de estar obedecendo ao pai. ${ }^{45}$ Ainda assim, a grande dedicação dela na conquista da empreitada que proporcionará a elevação de classe nos parece clara. Tentaremos demonstrar no texto as indicações que comprovariam nossa sugestão. Por enquanto, vejamos apenas um pequeno trecho da discussão entre o Padre Melchior e a protagonista acerca do possível casamento da moça com Mendonça, amigo sem posses de seu irmão:

" _ Se ele insistir, vencê-lo-ei, ou por um modo ou por outro. Uma moça que quer ser noiva, vale por um exército; eu sou um exército.

_ Muito bem! Contudo sua dignidade...

_ Oh! Em último caso abro mão da herança.

- Era capaz disso? Perguntou Melchior. veemência.

- Se era capaz? Desejo-o até, disse a moça com

E acrescentou em tom mais brando:

_ Sobre o homem de minha escolha desejo que não paire a mínima desconfiança." ${ }^{46}$

\footnotetext{
${ }^{45}$ Este é o argumento de Roberto Schwarz ao defender a falta de ambição de Helena: "Assim, se é verdade que Helena passa de uma família pobre para outra rica, não era esta a sua finalidade, contrariamente a Guiomar. Obedecia ao pai.", op.cit., p. 118.

${ }^{46}$ Helena, p. 352.
} 
Temos, nesse pequeno diálogo, uma síntese do procedimento de Machado ao tratar de maneira sutil o arrivismo em Helena. Suas características benevolentes superam o projeto de ascensão, mas a presença deste, mesmo que discreta, parece evidente na composição da personagem. A primeira fala de Helena demonstra sua enorme força de vontade para alcançar o que almeja, a qual é estrategicamente seguida pelo questionamento de Melchior acerca de sua dignidade. A próxima linha é muito significativa, porque nos permite contestar o argumento muito difundido de que ela seja uma heroína absolutamente desinteressada na posição que a nova família Ihe daria: “_ Em último caso abro mão da herança." Não temos aqui: “_ Eu vou abrir mão da herança" ou "_Se for preciso, abro mão da herança." O termo "em último caso" e sobretudo a palavra "último" revelam sim uma inclinação, mesmo que velada, por esses bens. Logo em seguida, percebemos o proceder machadiano de atenuar a afirmação anterior com a reiteração de Helena em desfazer-se da herança que lhe cabe. Assim, virtude e interesse são características que se alternam para que a primeira suavize os efeitos da segunda sem que nenhuma perca sua intensidade. Tal artifício pode ser notado em toda obra romanesca de Machado, na qual a sugestão aparece com muito mais frequência que o dado explícito.

Passemos agora ao romance francês. Em Proust, o arrivismo é manifesto, explicado e, muitas vezes, descolado dos conceitos de honestidade e dignidade. ${ }^{47}$ Apesar de possuírem qualidades que as ajudem a conquistar

\footnotetext{
47 Apesar de o arrivismo ser representado, na maioria das vezes, pressupondo falta de escrúpulos da personagem, optamos por trabalhar com definições variadas e mais abrangentes do termo, como vistas no capítulo I. Consideramos, desse modo, a vontade e o esforço de
} 
seu espaço, Odette e Madame Verdurin representam seres despreocupados com zelo a escrúpulos. Nesse sentido, percorrem seus caminhos mais livremente, não precisando respeitar nenhuma ordem familiar ou moral. Talvez sejam essas as razões pelas quais ultrapassam o longo intervalo temporal do texto, beneficiando-se das mudanças políticas e sociais, ao passo que outras personagens se deixam afetar negativamente pelas mesmas. Odette e Madame Verdurin constituem elementos perenes do texto, fazendo com que suas trajetórias individuais apresentem exemplos das grandes transformações gerais sofridas pela sociedade ali representada.

O todo formado pelos sete volumes de À la recherche du temps perdu compreende a aparição de centenas de personagens. Por ser um roman-fleuve de grandes ambições, no sentido de abarcar diversos núcleos espaciais e temporais, é natural que a presença de muitas dessas figuras se restrinja a apenas alguns dos volumes, embora o autor cite e recupere constantemente dados mencionados anteriormente. Ou seja, o desenvolvimento delas se concentra com mais força em determinada fase da obra, mesmo que continuem a ser referidas e resgatadas. As tias-avós, a avó e o avô, apesar de aparecerem durante boa parte do conjunto, são configurados detalhadamente, sobretudo, na fase inicial de Du côté de chez Swann e À l'ombre des jeunes filles en fleurs. Albertine, por sua vez, aparece de forma avassaladora na seção intermediária, mas pouco no início e no fim. Gilberte, tão marcante no início da adolescência de Marcel, deixa de ser mencionada a partir de Le Côté de Guermantes para ressurgir somente próximo ao desfecho, com atuação

obter sucesso na ascensão social, observados em Guiomar e Helena, também como procedimento arrivista. 
importante no tocante ao nosso tema. Já o mesmo não ocorre com Odette e Madame Verdurin. Elas participam de todas as fases da história antecedendo, inclusive, o nascimento de Marcel, e perduram até o evento final, a matinée dos Guermantes. Ambas não são apenas mencionadas, mas continuamente trabalhadas pelo narrador, ocupando posições significativas nos inúmeros períodos representados na obra. Suas trajetórias começam já na vida adulta, depois de casadas - Odette é separada de Monsieur de Crécy em "Un amour de Swann" - , entretanto, persistem por quatro décadas, de maneira que passam pelas inúmeras mudanças do tempo, do espaço e das ideias. Segundo Cynthia Gamble, a perenidade da presença de Odette e suas sucessivas fases propiciam algumas demarcações temporais precisas:

"A main character who is present throughout, is the courtesan Odette de Crécy (who ascends in society through her sexual favours with wealthy men), later to become Mme Swann and subsequently Mme Forcheville: the sense of stability she gives to the novel by her continued, yet changing presence, allows Proust to attach temporal markers to and around her." 48

Ora, a mesma estabilidade proporcionada pela continuidade de Odette ocorre também com Madame Verdurin, pois as duas são construídas em paralelo. Mesmo após o casamento com Swann e o empenho em constituir seu próprio salão, Odette continua, ainda que distante, sendo, de certo modo, a referência da Patronne e vice-versa. Lembremos novamente a cena final, na propriedade dos príncipes de Guermantes, na qual voltam a reencontrar-se,

48 GAMBLE, Cynthia. "From 'Belle Époque' to Fisrt World War: the social panorama" in BALES, Richard (ed.) The Cambridge Companion to Proust. Cambridge University Press, 2001, p. 8. 
fazendo com que o leitor se lembre, ainda que remotamente, do tempo do primeiro salão da Rua Montalivet.

Isso posto, voltemos ao nosso ponto de partida, aos antecedentes cujos alicerces permitem que nossas personagens edifiquem um destino diverso daquele ao qual seriam condenadas, caso dependessem exclusivamente do nascimento. Nos três romances machadianos, percebemos muitas similitudes na descrição do início de vida de Guiomar, Helena e Sofia. Com alguma variação na infância mais ou menos difícil - as famílias de Guiomar e Helena parecem ser mais carentes que a de Sofia -, a solução do narrador que consiste em ressaltar as dificuldades iniciais com intuito de valorizar as futuras conquistas se assemelha muito. Vejamos alguns exemplos:

"Guiomar tivera humilde nascimento; era filha de um empregado subalterno não sei de que repartição do Estado, homem probo, que morreu quando ela contava apenas sete anos, legando à viúva o cuidado de a educar e manter.[...]

A casa em que moravam era naturalmente modesta. Ali correu a infância, - mas solitária, o que é um pouco mais grave. [...]

Com o tempo, avultou outra causa de tristeza para a nobre viúva, ainda mais dolorosa que a primeira, $\mathrm{Na}$ idade de apenas dez anos, tinha Guiomar uns desmaios de espírito, uns dias de concentração e mudez, uma seriedade, a princípio intermitente e rara, depois frequente e prolongada, que desdiziam da meninice e faziam crer à mãe que eram prenúncios de que Deus a chamava para si. Hoje sabemos que não eram. Seria acaso efeito daquela vida solitária e austera, que já lhe ia afeiçoando a alma e como que apurando as forças para as pugnas da vida?" 49

\footnotetext{
${ }^{49}$ A mão e a luva, pp. 215, 216.
} 
No trecho acima, notamos uma sequência de termos caracterizando a origem desprivilegiada de Guiomar. Pobreza, obscuridade paterna, luto e condição precária de moradia são aspectos negativos a serem superados um a um por ela. A não conformidade da menina se acentua com o passar do tempo e no curto período de três anos seus sintomas físicos fazem transparecer as agruras dos sentimentos. O questionamento do narrador sinaliza o começo da constituição do caráter obstinado da personagem, traço fundamental de seu processo de formação. A concentração e seriedade, reveladas tão cedo, em idade pueril, permitirão firmeza no momento mais decisivo, o da escolha do pretendente, como veremos mais adiante.

O desprestígio da ascendência de Guiomar, "filha de um empregado subalterno não sei de que repartição do Estado", ressurgirá também em Quincas Borba, na única menção do narrador a respeito da vida de Sofia anterior ao casamento:

"A bela dama é filha de um velho funcionário público. Casou aos vinte anos com este Cristiano Palha, zangão da praça, que então contava vinte e cinco. O marido ganhava dinheiro, era jeitoso, ativo, e tinha o faro dos negócios e das situações." 50

Talvez não haja, em Quincas Borba, uma retrospectiva do passado de Sofia a propósito da infância, porque o narrador irá concentrar-se na adaptação dela e do marido como figuras interdependentes, ou seja, evoluindo como um bloco único. Não obstante, é possível destacar algumas informações relevantes da curta passagem acima. A insignificância do nome de nascença - "filha de

\footnotetext{
${ }^{50}$ Quincas Borba, pp. 668, 669.
} 
um velho funcionário público" - colocada junto ao dado do casamento com "o zangão da praça"51, que "ganhava dinheiro" e "tinha o faro dos negócios", indica a tendência da moça para buscar para si posição mais elevada do que a família ocupara.

Em Helena, observamos algo semelhante, quando D. Úrsula e Estácio recebem a notícia da existência de outra filha do conselheiro:

"D. Úrsula reprovou o todo do ato do conselheiro. Parecia-lhe que, a despeito dos impulsos naturais e licenças jurídicas, o reconhecimento de Helena era um ato de usurpação e um péssimo exemplo. A nova filha era, no seu entender, uma intrusa, sem nenhum direito ao amor dos parentes; quando muito, concordaria em que se lhe devia dar o quinhão da herança e deixá-la à porta. Recebê-la, porém, no seio da família e de seus castos afetos, legitimá-la aos olhos da sociedade, como ela estava aos da lei, não o entendia D. Úrsula, nem lhe parecesse que alguém pudesse entendê-lo. [...] Nada constava da mãe, além do nome; mas essa mulher quem era? Em que atalho sombrio da vida a encontrara o conselheiro? [...]

A impressão de Estácio foi outra. [...] A questão pecuniária pesou menos que tudo no espírito do moço; não pesou nada.[...] Quanto à camada social a que pertencia a mãe de Helena, não se preocupou muito com isso, certo de que saberiam levantar a filha até a classe a que ela ia subir." 52

As impressões de D. Úrsula se baseiam por completo na ilegitimidade social de Helena, já que, no contexto descrito pelo narrador, tal pertencimento teria mais peso que a paternidade biológica. A terminologia referente à origem

\footnotetext{
${ }^{51}$ Alfredo Bosi explica o sentido da expressão: "Quem é Palha? Um pulha. Um especulador, um corretor fraudulento da bolsa de valores, um "zangão da praça": "Figuras do narrador machadiano" in Cadernos de Literatura Brasileira, n. 23/24, jul 2008, Instituto Moreira Salles, São Paulo, p. 136.

${ }^{52}$ Helena, p. 278.
} 
da personagem é extremamente negativa a ponto de ser degradante. As expressões "fruto de uma usurpação" e "péssimo exemplo" deixam clara a preponderância da situação social sobre a vantagem estritamente financeira. A divisão de bens não ofende tanto à senhora quanto o reconhecimento "aos olhos da sociedade" da filha resultante de um "atalho sombrio" na vida do irmão. Interessante notarmos aqui as possíveis conotações do termo "sombrio" vinculado a Helena. Se o somarmos ao pensamento ulterior de Estácio, o qual revela segurança na capacidade da irmã em adequar-se ao nível da família, podemos deduzir, de antemão, a passagem da menina de um ambiente desconhecido, irrelevante e nebuloso a um respeitado, reconhecido e visível a todos. Ao indicar claramente na última sentença a mudança de classe necessária à integração da protagonista, o narrador revela a mobilidade como um dos temas centrais a serem tratados.

A proveniência de esferas socialmente insignificantes de Odette de Crécy e Madame Verdurin, embora seja mencionada apenas algumas poucas vezes na Recherche, pode nos apontar alguns caminhos. Como referimos anteriormente, Proust não parte da infância ou da adolescência, privilegiando a trilha que percorrerão a partir da vida adulta. Temos poucas informações no que se refere à existência de ambas antes do primeiro salão de Madame Verdurin. Importa atentarmos para o fato de que as trajetórias de Odette e de Madame Verdurin são indissociáveis na abertura da obra. Os primeiros movimentos da escalada de ambas são mostrados de forma simultânea. A apresentação conjugada das duas ocorre logo no segundo parágrafo de "Un amour de Swann", na descrição do conjunto de indivíduos que compunham aquele círculo: 
"En dehors de la jeune femme du docteur, ils étaient réduits presque uniquement cette année-là (bien que Mme Verdurin fût elle-même vertueuse et d'une respectable famille bourgeoise excessivement riche et entièrement obscure avec laquelle elle avait peu à peu cessé volontairement toute rélation) à une personne presque du demi-monde, Mme de Crécy, que Mme Verdurin appelait par son petit nom, Odette [...]." 53

Dessa passagem podemos destacar alguns elementos. $O$ fato de Madame Verdurin vir de uma família riquíssima e totalmente desconhecida mostra o tipo de sociedade com a qual se está lidando. Não basta possuir riqueza abundante em um meio muito estratificado e regulado. Se, no pequeno núcleo fluminense retratado em Helena, a tradição familiar era fundamental, na França, mais precisamente em Paris, "capital do século XIX" nas palavras de Walter Benjamin, o pertencimento ou o acesso às famílias aristocráticas mais influentes era vital. Odette, por sua vez, além de ser uma femme entretenue, não desfruta de posses nem de influência com nenhum setor relevante. Raymonde Coudert retoma algo que a crítica já indicara, a péssima reputação da esposa de Swann nos domínios da família de Marcel em "Combray". Talvez, por ser o único núcleo familiar mais estável da obra, tal tabu seja tão forte:

“[...] il faut repartir à Combray: elle n'y a de place qu'interdite, on ne la reçoit pas, elle est infréquentable, on ne parle d'elle qu'à mots couverts." ${ }^{54}$

Saberemos mais tarde que seu nome, Madame de Crécy, foi herdado do antigo marido cujo dinheiro foi todo consumido por ela. Só posteriormente,

\footnotetext{
${ }^{53}$ Du côté de chez Swann, pp. 185, 186.

${ }^{54}$ COUDERT, Raymonde. Proust au féminin. Paris: Bernard Grasset/ Le Monde de l' Éducation, 1998, p. 44.
} 
tomaremos conhecimento de sua juventude pouco virtuosa em Nice, onde trabalhou como prostituta, antes mesmo do primeiro casamento. A expressão demi-monde indica aqui dois dados a um só tempo: caracteriza Odette, pois ela não tem entrada nos meios mais brilhantes e qualifica o salão Verdurin como inferior, enfatizando a completa irrelevância de ambas e do espaço ao qual pertencem. Logo adiante, voltaremos a ele para compreendermos melhor o palco dos avanços iniciais de Odette e Madame Verdurin.

Não podemos deixar de mencionar também a existência de cumplicidade entre os figurantes daquele salão, composto também por uma concierge (a tia do pianista), um médico iniciante e um pintor ainda desconhecido. A irrelevância social de tais integrantes será ressaltada por contraposição ao brilho de Swann no circuito mais elegante da aristocracia. Daí, a verdadeira razão da implicância de Madame Verdurin com o diletante. Lembremos que, para representar os diferentes núcleos da Recherche, Proust trabalha sempre com oposições sociais: Swann/Odette e Madame Verdurin, Saint-Loup/Rachel, Marcel/Albertine e Charlus/Morel. As constantes movimentações das personagens de um meio ao outro darão a tônica da narrativa. 
Adaptação notável de Guiomar e Helena

Verificamos em muitas personagens das mais variadas literaturas ${ }^{55}$ duas características fundamentais e predominantes nos trilhos do percurso ascensional: obstinação e grande capacidade de adaptação às novas situações. Como sabemos, tais traços são imprescindíveis também em Guiomar e Helena. Assim, faz-se necessário reiterar a existência de uma inclinação natural a um estilo de vida diferente daquele de origem, evidentemente superior no que concerne às questões materiais.

Guiomar anunciava desde pequena ser viva, inteligente e capaz de adequar-se rapidamente a cada nova situação que a vida lhe apresentava. Educada somente pela mãe até os treze anos, a menina é caracterizada como quem já tem potencial para ir além do que parecia ser o seu destino:

"Guiomar não tinha dificuldade nenhuma em reter o que a mãe Ihe ensinava, e com tal afinco lidava por aprender, que a viúva, - ao menos nessa parte, - sentia-se venturosa. Hás de ser a minha doutora, dizia-lhe muita vez; e esta simples expressão de ternura alegrava a menina e lhe servia de incentivo à aplicação. [...] tinha uma força de vontade superior aos seus anos. Com ela, e a viveza intelectual que Deus Ihe dera, logrou aprender tudo o que a mãe lhe ensinara, e melhor ainda do que ela o sabia, desde que o tempo lhe permitiu desenvolver os primeiros elementos." 56

\footnotetext{
${ }^{55}$ A título de exemplo podemos citar Fernando Seixas de Senhora (1874), de José de Alencar, Fanny Price de Mansfield Park (1814), de Jane Austen, além de Eugène de Rastignac, evidentemente.

${ }^{56}$ A mão e a luva, pp. 215, 216.
} 
Podemos constatar sua força ainda criança no conjunto de termos escolhidos. Seguindo a expressão duplamente negativa concernente a qualquer possível obstáculo - "não tinha dificuldade nenhuma" -, encontramos "afinco", "aplicação" e "força de vontade", termos antecipadores do perfil a ser formado. Do mesmo modo, o verbo "lograr" aponta paro um futuro certamente bem-sucedido.

A ambição nata passa a ser compreendida com o passar do tempo pela menina. Ainda que consciente das limitações e dificuldades impostas pelo nascimento humilde, a atração por um estilo de vida mais elevado torna-se inevitável. O trecho no qual Guiomar observa, com misto de encantamento e tristeza, moças ricas através da fenda do muro de sua casa é um dos momentos mais expressivos do texto:

"O muro no fundo tinha uma larga fenda, por onde se via parte da chácara pertencente a uma casa da vizinhança. A fenda era recente; e Guiomar acostumara-se a ir espairecer ali os olhos, já sérios e pensativos. Naquela tarde, como estivesse olhando para as mangueiras, a cobiçar talvez as doces frutas amarelas que lhe pendiam dos ramos, viu-lhe repentinamente aparecer-lhe diante, a cinco ou seis passos do lugar em que estava, um rancho de moças, todas bonitas, que arrastavam por entre as árvores os seus vestidos, e faziam luzir aos últimos raios do sol poente as joias que as enfeitavam. Elas passaram alegres, descuidadas, felizes; uma ou outra Ihe dispensou um afago; mas foram-se, e com elas os olhos da interessante pequena, que ali ficou largo tempo absorta, alheia de si, vendo ainda na memória o quadro que passara." 57

${ }^{57}$ A mão e a luva, p. 216. 
A cena acima, já estudada pela fortuna crítica $^{58}$, é emblemática no sentido de simbolizar a trajetória singular a ser trilhada por Guiomar. Para vencer, é preciso atravessar a fenda, deixar a existência antiga e ingressar em outro universo. A associação entre riqueza e felicidade está clara; Guiomar, pobre, tem "olhos sérios e pensativos", ao passo que as moças abastadas e bem-vestidas são "alegres", "descuidadas" e "felizes". Fica patente, em tal caracterização, a oposição entre a preocupação constante dos que têm origem desprivilegiada e a despreocupação dos afortunados. A perfeita conjugação entre a paisagem e os adereços também aparece com frequência no texto. $O$ artifício, em A mão e a luva, seja dos gestos, das roupas ou dos ornamentos, aperfeiçoa o que a natureza criou. Do mesmo modo, as "doces frutas amarelas" relacionadas às moças ricas aludem tanto aos prazeres do conforto material quanto indicam a possibilidade de Guiomar, em seu amadurecimento, passar da "cobiça" ao desfrute de semelhante vivência.

Retornemos novamente à argúcia de Guiomar, que se mostra ainda mais admirável quando, por uma sucessão de tragédias - a morte de sua mãe e de Henriqueta, filha da madrinha -, tem a chance de ocupar o lugar da herdeira da rica baronesa e de tornar-se o principal objeto de afeição por parte desta.

Apesar de muito jovem, Guiomar é lúcida e possui "viveza intelectual". Tem verdadeiro afeto pela madrinha, mas não descuida de preparar o caminho que passa a trilhar daquele momento em diante, pois essa constitui a sua

\footnotetext{
${ }^{58}$ Sobretudo no ensaio de Alfredo Bosi: "A máscara e a fenda" in BOSI, Alfredo et alli. Machado de Assis, São Paulo: Ática, 1982, pp.437-457.
} 
melhor, talvez única, chance de lograr sucesso e corresponder aos seus anseios. O empenho em adaptar-se à nova vida se mostra constante:

\begin{abstract}
"Guiomar correspondia aos sentimentos daquela segunda mãe; havia talvez em seu afeto, aliás sincero, um tal encarecimento que podia parecer simulação. O afeto era espontâneo; o encarecimento é que seria voluntário. [...] Pouco depois estabeleceu-se Guiomar definitivamente em casa da madrinha, onde a alegria reviveu, gradualmente, graças à nova moradora, em quem havia um tino e sagacidade raros. Tendo presenciado, durante algum tempo, e não breve, o modo de viver entre a madrinha e Henriqueta, Guiomar pôs todo o seu esforço em reproduzir pelo mesmo teor os hábitos de outro tempo, de maneira que a baronesa mal pudesse sentir a ausência da filha." 59
\end{abstract}

Observamos acima mais um pouco da composição tipicamente machadiana cujos paradoxos têm funções complementares, ou seja, ali os termos opostos não se excluem, mas, ao contrário, combinam-se com o intuito de trazer à tona as duas facetas de Guiomar. ${ }^{60} \mathrm{O}$ afeto é sincero, porém o encarecimento seria simulado, de maneira que a personagem se esforça além dos sentimentos verdadeiros para alcançar seus propósitos. A última frase do trecho confirma nossa sugestão: para minimizar ao máximo o sofrimento da baronesa, a astúcia conta tanto ou mais que o carinho na reprodução exata dos hábitos de outrora entre mãe e filha.

\footnotetext{
${ }^{59}$ A mão e a luva, pp. 216, 217.

${ }^{60}$ Partimos da seguinte formulação de Roberto Schwarz para aprofundarmos, em seguida, nossa análise textual: "O leitor terá sentido a dubiedade da exposição, que traz os antagonismos costumeiros entre espontâneo e voluntário, sincero e simulado, sentimento e interesse - para negar-Ihes a pertinência: os cálculos, de que são o prolongamento, e se acaso incitam às efusões um pouco sublinhadas, não fazem mal, fazem até bem.", op. cit., p. 96.
} 
Alfredo Bosi observa que esse tipo de relação combina "um interesse econômico inegável com uma tática de aproximação e envolvimento afetivo"61 do parente rico por parte do carente. Para o crítico, Guiomar é uma das personagens femininas mais determinadas da obra machadiana, pois suas ações se baseiam na "fria eleição do espírito" 62 .

A frieza, aliás, pode ser considerada uma das características mais ressaltadas da personagem. O narrador insiste nesse aspecto, delineando-o de diversas maneiras, seja na caracterização psicológica ou em suas atitudes e gestos. Há vários exemplos e eles aparecem em diferentes circunstâncias. Quando se encontra com Estevão, mostra-se "tranqüila e fria, sempre polida e grave, risonha às vezes, mas de um risonho à flor do rosto, que não lhe alterava a serenidade e compostura". ${ }^{63}$ Despede-se dele "com um gesto friamente fidalgo". ${ }^{64}$ Mrs. Oswald a descreve assim para a baronesa: "Sua afilhada tem uma alma singular; passa facilmente de entusiasmo à frieza, e da confiança ao retraimento". ${ }^{65}$ Em uma discussão com a mesma governanta, Guiomar "olhou fria e longamente para a inglesa, com um desses olhares, que são, por assim dizer, um gesto da alma indignada". ${ }^{66}$ Também fria e imutável ao ler a declaração de Jorge, um de seus pretendentes: "Guiomar leu a carta duas vezes, uma leitura de curiosidade, outra de análise e reflexão, e ao cabo da segunda achava-se tão fria como antes da primeira". ${ }^{67} \mathrm{E}$ até na descrição

\footnotetext{
${ }^{61}$ BOSI, Alfredo, "A máscara e a fenda", op. cit., p. 437.

${ }^{62}$ A mão e a luva, p. 253.

${ }^{63}$ Idem, p. 210.

${ }^{64}$ Idem, p. 211.

${ }^{65}$ Idem, p. 214.

${ }^{66}$ Idem, p. 222.

${ }^{67}$ Idem, p 224.
} 
de sua silhueta na significativa passagem em que o narrador menciona a mineralidade de sua feição: "Na meia sombra que ali havia destacava-se o rosto marmóreo de Guiomar e a gentileza de seu talhe". ${ }^{68}$ Não seria exagero dizer que, acerca dessa característica mineral, marmórea, o comentário que Antonio Candido ${ }^{69}$ faz a respeito de Aurélia Camargo, a protagonista de Senhora de José de Alencar, cabe mais ainda para descrever Guiomar. Tal traço faz transparecer o afinco com o qual a jovem tenta conduzir seu destino, pois ele é fundamental para que as decisões sejam tomadas sempre de forma objetiva e analítica. $^{70}$

Contudo, não podemos deixar de apontar a forte presença da construção do laço de mãe e filha entre a personagem órfã e a figura materna. Além da conveniência prática à comodidade de ambas, a resolução da questão sentimental completa um cenário favorável em todos os aspectos. A identificação verdadeira de Guiomar com a madrinha rica ocorre, inclusive, pelo sentimento de afinidade da moça com uma classe acima da que viera. $\mathrm{O}$ dado da afeição suaviza o traço arrivista da heroína, tornando-a mais interessante e

\footnotetext{
${ }^{68}$ A mão e a luva, p. 218.

${ }^{69}$ CANDIDO, Antonio. "Crítica e sociologia" in Literatura e sociedade. São Paulo: Companhia Editora Nacional, 1975. 4a Ed., p. 6: "A heroína, endurecida no desejo de vingança, possibilitada pela posse do dinheiro, inteiriça a alma como se fosse agente duma operação de esmagamento do outro por meio do capital, que o reduz a coisa possuída. E as próprias imagens do estilo manifestam a mineralização da personalidade, tocada pela desumanização capitalista, até que a dialética romântica do amor recupere a sua normalidade convencional."

${ }^{70} \mathrm{O}$ desenvolvimento da ideia da esperteza e da frieza de Guiomar é recuperado e reproduzido de nossa dissertação de mestrado, pois a mesma explanação lá exposta nos é bastante útil também nesta tese. Por ser um trecho curto, cuja maior parte são as mesmas citações do romance que seriam utilizadas aqui, tomamos a liberdade de transcrevê-lo neste capítulo: SILVA, Maria Elvira Lemos da. A representação do arrivismo social em Le rouge et le noir de Stendhal e A mão e a luva de Machado de Assis. Universidade de São Paulo, 2011 (inédita), pp. 49-52.
} 
complexa. Assim, como sabemos, o movimento do texto machadiano é construído por afirmações e negaças - "afeto espontâneo" e "carecimento voluntário" -, em que se alternam um desvelar e um velar, fazendo com que a narrativa seja sinuosa, com direções múltiplas.

Em Helena, verificaremos uma constituição da personagem semelhante à vista em $A$ mão e a luva. Antes da morte do conselheiro, somente Camargo tem conhecimento da filha que aquele deixara. Já na leitura no testamento, no capítulo II, o médico antecipa a principal qualidade da filha, a dedicação:

“_ [...] O que está feito, está feito. Uma vez reconhecida, essa menina deve achar nesta casa família e afetos de família. Persuado-me de que ela saberá corresponder-lhes com verdadeira dedicação..." ${ }^{71}$

Logo em seguida, antes de passar à descrição de Helena, o narrador retrata a mãe de Estácio, cujo sofrimento será revivido por Helena, e seu filho. Vejamos:

"A mãe de Estácio era diferente; possuíra em alto grau a paixão, a ternura, a vontade, uma grande elevação de sentimentos, com seus toques de orgulho, daquele orgulho que é apenas irradiação da consciência. [...] As mulheres que são apenas mulheres, choram, arrufam-se ou resignam-se; as que têm alguma coisa mais do que a debilidade feminina, lutam ou recolhem-se à dignidade do silêncio." 72

"Juntava às outras qualidades morais uma sensibilidade, não feminil ou doentia, mas sóbria e forte; áspero consigo, sabia ser terno com os outros.

Tal era o filho do conselheiro; se alguma coisa há ainda que acrescentar, é que ele não cedia nem esquecia nenhum dos direitos e deveres que lhe davam a idade e a classe em

\footnotetext{
${ }^{71}$ Helena, p. 278.

72 Idem, pp. 279, 280.
} 
que nascera. Elegante e polido, obedecia à lei do decoro pessoal, ainda nas menores partes dela. Ninguém entrava mais ${ }_{73}$ corretamente numa sala; ninguém saía mais oportunamente."

Em relação aos substantivos utilizados na composição da mãe de Estácio, fica clara a associação com Helena. Será possível constatar nela os mesmos traços no decorrer de sua adaptação ao novo núcleo familiar. Além disso, tais similaridades anunciam também o desfecho do romance.

Quanto a Estácio, o que mais chama a atenção é a adequação perfeita do moço à sua classe. Sua correção de gestos, apesar de exageradamente impecável, corresponde ao que se espera da elite. Esse exagero parece ter a função de enfatizar as virtudes de Helena, pois, se nele tais qualidades são adquiridas mais naturalmente devido às vantagens de sua posição, na moça os atributos devem ser muito mais celebrados, já que foram conquistados em situação adversa.

Todavia, o alinhamento de Helena aos costumes da tia e do irmão parece fácil demais. No intervalo de apenas três dias, ela passa do "acanhamento" à "familiaridade":

"Helena, posto forcejasse para estar senhora de si, não conseguia vencer de todo o natural acanhamento da ocasião. [...] Mas a asa do tempo leva tudo; e ao cabo de três dias, já a fisionomia de Helena trazia menos sombrio aspecto. O olhar perdeu a expressão que primeiro lhe achou o irmão, para tornar-se o que era naturalmente, mavioso e repousado. A palavra saía-lhe mais fácil, seguida e numerosa; a familiaridade tomou o lugar do acanhamento." 74

\footnotetext{
${ }^{73}$ Helena, p. 280.

${ }^{74}$ Idem, p. 283.
} 
Ora, não seriam três dias um período muito curto para uma completa desconhecida familiarizar-se com um ambiente onde nunca estivera anteriormente? Sim, quando se trata do comportamento padrão, mas Helena e Guiomar estão para além dele nesse aspecto. Sendo a única opção de uma vida melhor, a integração ao novo lar se faz absolutamente necessária, para o que concorrem a elegância e a graça discreta de ambas:

"Fosse influência do lugar ou simples mobilidade do espírito, Helena tornou-se logo outra do que se revelara no gabinete do pai. Jovial, graciosa e travessa, perdera aquela gravidade quieta e senhora de si com que aparecera na sala de jantar; fez-se lépida e viva, como as andorinhas que antes, e ainda agora, esvoaçavam por meio das árvores e por cima da grama. [...] Helena pareceu-lhe naquela ocasião, mais do que antes, o complemento da família. O que ali faltava era justamente o gorjeio, a graça, a travessura, um elemento que temperasse a austeridade da casa e lhe desse todas as feições necessárias ao lar doméstico. Helena era esse elemento complementar." ${ }^{75}$

A expressão "mobilidade de espírito" possui conotação dúbia, revelando tanto o domínio em variar facilmente de comportamento quanto a recente mudança de classe social. Notamos nos mais variados romances de mesmo tema um ponto comum. As figuras recém-chegadas devem tornar-se indispensáveis para serem acolhidas. Elas precisam trazer algo novo e complementar as lacunas como poucos poderiam fazê-lo. Pensando em Julien Sorel e Eugène de Rastignac, percebemos sempre uma postura inovadora que os tornam importantes naquelas conjunturas. Assim são Guiomar e Helena, pois passam de inexistentes a fundamentais.

\footnotetext{
${ }^{75}$ Helena, p. 285.
} 
O narrador insiste na excelência de sua postura:

"O que a tornava superior e Ihe dava probabilidade de triunfo, era a arte de acomodar-se às circunstâncias do momento e a toda a casta de espíritos, arte preciosa, que faz hábeis os homens e estimáveis as mulheres. Helena praticava de livros ou de alfinetes, de bailes ou de arranjos de casa, com igual interesse e gosto, frívola com os frívolos, graves com os que o eram, atenciosa e ouvida, sem entono nem vulgaridade.[...] Mediante os seus recursos, e muita paciência, arte e resignação, - não humilde, mas digna, - conseguia polir os ásperos, atrair os indiferentes e domar os hostis." 76

Ora, a escolha da palavra "triunfo" remete ao caráter da obra, complementando e justificando a ideia de vitória, seguida de uma série de estratégias que possibilitam a conquista de todos que a rodeiam. Hábil e sutilmente o narrador retoma, às vezes, a possível premeditação de Helena sem comprometer, todavia, sua amabilidade:

"Pouco havia ganho no espírito de D. Úrsula; mas a repulsa desta já não era tão viva como nos primeiros dias. Estácio cedeu de todo, e era fácil; seu coração tendia para ela, mais que nenhum outro. Não cedeu, porém, sem alguma hesitação e dúvida. A flexibilidade do espírito da irmã afigurou-se-lhe a princípio mais calculada que espontânea." 77

Vemos, como nos exemplos já analisados, a mesma solução da qual Machado lança mão para atenuar a percepção de puro interesse. As atitudes calculadas são sempre camufladas imediatamente após serem lançadas:

\footnotetext{
${ }^{76}$ Helena, p. 286.

${ }^{77}$ Idem.
} 
"Nos primeiros dias de agosto a situação de Helena podia dizer-se consolidada. D. Úrsula não cedera de todo, mas a convivência ia produzindo seus frutos. Camargo era o único irreconciliável; sentia-se, através de suas maneiras cerimoniosas, uma aversão profunda, prestes a converter-se em hostilidade, se fosse preciso. As demais pessoas, não só domadas, mas até enfeitiçadas, estavam às boas com a filha do conselheiro." 78

O único resistente até o fim será Camargo, mas ele o faz por interesses próprios. ${ }^{79}$ Apenas o médico sabe da verdadeira paternidade de Helena, o que a torna rival direta dos planos do casamento vantajoso entre sua filha, Eugênia, e Estácio. Todo o restante sucumbe ao feitiço irresistível da jovem, inclusive D. Úrsula. Aliás, podemos fazer um paralelo entre A mão e a luva e Helena a esse respeito.

Em ambos os casos, as heroínas se deparam com obstáculos surgidos da convivência delicada com as figuras estabelecidas nas casas. Guiomar e Helena parecem representar tipos singulares, pois a origem inferior não interfere na excelência de sua postura. Apesar de não encontrarem quase nenhum empecilho na interação com as figuras centrais, a baronesa e Estácio, elas têm de superar as barreiras com as adjacentes, Mrs Oswald e D. Úrsula.

A governanta e a tia se configuram como principais entraves na ascensão das personagens, porque representam a estabilidade da sociedade,

\footnotetext{
${ }^{78}$ Helena, p. 288.

${ }^{79}$ STEIN, Ingrid, op. cit., p. 60: "[...] o Dr. Camargo, pai de uma filha adolescente, Eugênia, procura convencê-lo a fazer carreira política. Sua intenção é casar a filha com Estácio - e seu empenho em cuidar do futuro dele é "um meio de dar certo relevo público ao da filha, e, por um efeito retroativo, a ele próprio, cuja vida fora tanto ou quanto obscura."
} 
garantida por regras e hábitos bem estabelecidos. As moças recém-chegadas, por outro lado, além de virem de classe inferior, trazem mudança e novidade, de modo a reorganizar as estruturas familiares acostumadamente engessadas. A tensão entre velhice e mocidade travada no período de adaptação deixará de existir com a demonstração irrefutável de harmonia oferecida pelas protagonistas ao cabo de pouco tempo. Para tanto, esforços não são medidos:

"[...] dizendo que a casa e a chácara the pareciam bonitas e bem dispostas, pediu a D. Úrsula que lhas fosse mostrar mais detidamente. A tia fechou o rosto e secamente respondeu:

_ Agora não, menina; tenho por hábito descansar e ler.

- Pois eu lerei para a senhora ouvir, replicou a moça com graça; não é bom cansar os seus olhos; e, além disso, é justo que me acostume a servi-la, Não acha? Continuou ela voltando-se para Estácio.

- É nossa tia, respondeu o moço.

- Oh! Ainda não é minha tia! Interrompeu Helena. Há de sê-lo quando me conhecer de todo. Por enquanto somos estranhas uma à outra; mas nenhuma de nós é má." 80

O tom de conquista aí é inegável. Helena coloca-se como solícita, mas age com firmeza, ou seja, alia o costume vigente à mudança proposta pela juventude. A proposição de ler para a tia não está colocada como um questionamento e sim como uma quase imposição. Isso faz com que a subserviência desapareça dando lugar à segurança. Tal solidez, colocada sempre graciosamente, acaba por enternecer D. Úrsula, pois the proporciona afeto e conforto renovados. Novamente, assistimos à plena consciência da heroína no que se refere à necessidade de conquistar seu espaço. O texto alterna harmoniosamente o discurso indireto e o direto, reforçando a

\footnotetext{
${ }^{80}$ Helena, pp. 283, 284.
} 
afabilidade de Helena, a aspereza de D. Úrsula e a cordialidade de Estácio, estabelecendo, desse modo, momentos e gradação de sedução.

Como se percebe, o narrador busca equalizar a figura de Helena ("mas nenhuma de nós é má"), dando-Ihe contornos mais amplos do que aquele conferido pelo simples interesse. O fim da obra saberá aureolar a personagem que, apesar de jovem, terá acarretado mudanças significativas na vida dos que a cercam.

Constatamos, portanto, similaridades significativas na constituição das protagonistas de $A$ mão e a luva e Helena. Talento natural e empenho deliberado se conjugam para formar uma personalidade merecedora de êxito. Tais predicados são interdependentes, pois o segundo não seria tão eficiente sem a existência do primeiro. Em relação a Sofia, Odette e Madame Verdurin, verificamos também grande esforço por parte delas para serem reconhecidas, mas os textos estão organizados de outra maneira. Nesses casos, seguimos os desdobramentos sociais de mulheres já casadas ou em vias de casar-se. O ponto de partida aqui pressupõe o casamento, ao passo que em $A$ mão e a luva e Helena, ele representa o desígnio final. Assim, seja como objetivo principal ou pressuposto indispensável, essa instituição parece ser fundamental nas composições brasileira e francesa. 
O casamento como melhor opção

A análise de nossos textos aponta para a constatação de que o casamento tem peso inquestionável na solidificação do espaço social do casal, tanto para a mulher quanto para o homem, ainda que ela seja sensivelmente mais vulnerável que ele. ${ }^{81} \mathrm{Na}$ conjuntura brasileira do século XIX o matrimônio é vital, pois proporciona segurança e um mínimo de liberdade às mulheres, ao mesmo tempo em que promove a respeitabilidade dos homens. Na França da Belle Époque e no universo proustiano, a aliança envolve interesses mais amplos, determinando declínio ou ascensão numa esfera muito estratificada, transferindo fortunas e títulos de maneira a rearranjar as regras até então estabelecidas.

Os enredos brasileiros deste estudo estão situados a partir da metade do século XIX, todos no Rio de Janeiro. Nesse contexto, não nos surpreendemos com as quase inexistentes possibilidades profissionais para 0 público feminino, visto que o desprestígio do trabalho já se encontrava na raiz da questão. As meninas de boa família não iam à escola; eram educadas preferencialmente em casa, onde recebiam instruções básicas para o convívio social como línguas, noções de música, bordados e desenho com o intuito de serem ótimas esposas. Segundo Ingrid Stein:

\footnotetext{
${ }^{81}$ STEIN, Ingrid, op. cit., p. 32: "Casar-se representava na vida da mulher uma função importantíssima, pois só com isto ela obtinha status social mais elevado: como se viu, as alternativas, além de pouco sedutoras, acarretavam um adicional desprestígio. Para a mulher como para o homem - o casamento podia implicar ascensão social, mas, para ela, esta era a única maneira de alcançá-la, uma vez que não se the permitiam atividades que the possibilitassem promover-se socialmente por esforço próprio."
} 
"Não é exagero afirmar que o casamento colocava-se, para as mulheres, no mesmo nível que profissão, carreira política ou riqueza para os homens." ${ }^{82}$

Mas, para as moças desfavorecidas ou órfãs, o ingresso escolar se apresentava muitas vezes como a alternativa remanescente. ${ }^{83}$ Não temos informações acerca da educação formal de Sofia, Odette e Madame Verdurin, porque sua corporificação narrativa se dá em plena campanha de ascensão, lutando com as armas que Ihes parecem úteis: dinheiro, corpo, sedução pessoal e social. Mais uma vez, localizamos elementos parecidos no que concerne à formação de Guiomar e Helena. Em ambos os casos, a permanência no colégio ocorre por ser a única opção viável. Caso o casamento falhasse, elas teriam uma forma de sustento, mesmo que modesta. ${ }^{84}$

Antes da transferência para as casas ricas, Guiomar e Helena estão na escola completando seus estudos:

\footnotetext{
${ }^{82}$ STEIN, Ingrid, op. cit, p. 65.

${ }^{83}$ Ibidem, p. 32. "A única possibilidade de comunicação com o exterior e atuação fora do lar era o exercício do magistério primário. Esta profissão era admitida exclusivamente para a mulher de classe média e, assim mesmo, com restrições: preferivelmente, ela não deveria exercer nenhuma atividade remunerada, pois isto implicava queda do nível social. A carreira de professora era antes reservada àquelas com menos recursos e que se vissem obrigadas a trabalhar."

${ }^{84}$ Confirmando as informações levantadas por Stein, a socióloga Heleieth Saffioti reitera, também, que a formação para a profissão de professora primária constitui-se como possibilidade profissional, ainda que não fosse esse o desejo da maioria das meninas cujo alvo principal era o bom casamento: "Como as escolas normais visavam, precipuamente, à qualificação profissional de quadros para o ensino primário, destinam-se, de preferência, às camadas pouco privilegiadas pela fortuna. Estas, num país de alto índice de analfabetismo, não aspiram à instrução como veículo de ascensão social, só vindo a fazê-lo quando os efeitos da industrialização e da urbanização intensa se tornam presentes.", A mulher na sociedade de classes: mito e realidade. Petrópolis: Vozes, 1979, p. 198.
} 
"Tinha a moça dezesseis anos quando passou para o colégio da tia de Estêvão, onde pareceu à baronesa se lhe poderia dar mais apurada educação. Guiomar manifestara o desejo de ser professora.

- Não há outro recurso, disse ela à baronesa quando the confiou esta aspiração.

Como assim? Perguntou a madrinha.

- Não há, repetiu Guiomar. Não duvido, nem posso negar o amor que a senhora me tem; mas a cada qual cabe uma obrigação, que se deve cumprir. A minha é... é ganhar o pão.

Estas últimas palavras passaram-lhe pelos lábios como que à força. $O$ rubor subiu-lhe as faces; dissera-se que a alma cobria o rosto de vergonha." 85

"_Além disso, essa menina nenhuma culpa tem de sua origem, e visto que meu pai a legitimou, convém que não se ache aqui como enjeitada.

[...] D. Úrsula ficou triste e só. Aparecendo Camargo daí a pouco, ela confiou-lhe todo o seu modo de sentir, que o médico interiormente aprovava.

Conheceu a mãe dela? Perguntou a irmã do conselheiro.

- Conheci.

- Que espécie de mulher era?

- Fascinante.

- Não é isso; pergunto-lhe se era mulher de ordem inferior, ou...

_ Não sei; no tempo em que a vi, não tinha classe e poderia pertencer a todas [...]

Helena estava a concluir os estudos; semanas depois determinou a família que ela viesse para casa." ${ }^{86}$

Na primeira passagem, a vinculação do estudo formal à necessidade fica

evidente. Tratada como recurso derradeiro, a profissionalização não se relaciona de nenhum modo com o aprimoramento pessoal, tendo como finalidade exclusiva o sustento. Nesse momento, tal associação enfatiza o descontentamento de Guiomar com um futuro medíocre. A questão posta toda

\footnotetext{
${ }^{85}$ A mão e a luva, pp. 216, 217.

${ }^{86}$ Helena, p. 281.
} 
em forma de diálogo parece tomar empréstimo à arte teatral, pois faz com que o leitor experimente o "drama" da personagem desamparada, problema, aliás, bem conhecido do público devido à sua grande incidência. ${ }^{87}$

O recorte de Helena não revela de maneira tão explícita a circunstância desfavorável de se frequentar o colégio, já que localizamos apenas a breve menção do fato. Todavia, a sequência imediatamente anterior de comentários negativos a propósito de Helena e sua mãe, acrescenta uma conotação ruim ao ato de trabalhar. A inferioridade da genitora e a origem duvidosa da menina convergem para a solução mais apropriada nesse tipo de caso: a escola.

Assim, confirmamos a precedência do casamento em detrimento de qualquer forma de atividade remunerada. Em $A$ mão e a luva, a recusa desse destino se ratifica em dois momentos: o estabelecimento na família abastada e, em seguida, a consolidação do casamento vantajoso. Helena só não tem o mesmo destino porque o romance se vira para a busca da completa redenção da heroína em seu desfecho. Nesse aspecto, Machado parece filiar-se a Stendhal ao optar pela supremacia da paixão, apesar da longa trajetória pontuada pela determinação em vencer. ${ }^{88}$ Já Sofia, Odette e Madame Verdurin empreendem verdadeira sociedade com seus maridos a fim de alavancarem

\footnotetext{
${ }^{87}$ A expectativa de vida no Brasil, por volta dos anos 1850, estava em torno de 40 anos de idade. Tal dado justificaria grande número de crianças e adolescentes órfãos.

${ }^{88}$ Seguimos a análise da obra stendhaliana, feita por Antonio Candido, no ensaio "Uma dimensão entre outras": "Os seus romances [...] não focalizam tipos banais. Os seus heróis têm sempre algo excepcional, - seja devido à aplicação intensa da vontade, seja pelo vigor da paixão. No meio dos homens, encarados sem benevolência, isola certos seres de exceção, que, por isso mesmo, devem formar uma supersociedade de espíritos superiores, na sociedade banal de que se destacam.", in O observador literário. Rio de Janeiro: Ouro sobre Azul, 2004, p. 75.
} 
suas posições mundanas. Retomaremos a questão em detalhe e as três personagens logo adiante.

Em A mão e a luva e Quincas Borba, as limitações femininas impostas pela conjuntura fazem com que a mulher se empenhe firmemente nas conquistas do marido, pois estas serão refletidas em si mesmas. A esse respeito, Stein comenta:

"Observa-se na análise das figuras femininas dos romances que existem algumas extremamente ambiciosas. Estas, como não têm a possibilidade de por si realizar suas aspirações, fazem convergir suas próprias ambições e energias para uma carreira alheia, a de seus maridos." ${ }^{89}$

A escolha de Luís Alves por Guiomar como melhor pretendente se deve às suas aspirações políticas e ao possível reconhecimento público decorrente delas. Ao perceber que o romantismo exacerbado de Estêvão e a letargia de Jorge não produziriam os resultados desejados, a personagem segue obstinada na decisão de unir-se ao advogado.

Sofia, já unida a um homem com tino para os negócios, continua a apoiar o marido em todas as suas empreitadas, inclusive nas mais discutíveis no tocante à moral, pois Cristiano Palha avaliza a contínua cooptação sedutora de Rubião por parte dela. Apesar de hesitar inicialmente apenas para demonstrar certa compostura de mulher casada, ela prossegue com o jogo de atrações e interesses ao perceber o risco de não permanecer nele.

Pudemos observar alguns exemplos da extrema importância do casamento na obra romanesca de Machado, mas ainda há outros. Em

\footnotetext{
${ }^{89}$ STEIN, Ingrid, op. cit., p. 66.
} 
Ressurreição e laiá Garcia tal assunto se configura também como um dos temas centrais; em Dom Casmurro o enlace se consolida, apesar do desfecho dramático; em Memorial de Aires, Fidélia desfruta da felicidade conjugal duas vezes. Além disso, o autor amplia a abordagem da questão quando trata das personagens femininas que não conseguem casar-se. D, Tonica, de Quincas Borba, é a representação modelar dessa infelicidade. Construída em contraposição a Sofia, a filha do major Siqueira deseja apenas um marido, porém ele nunca chega:

\begin{abstract}
"Agora, aquietada a imaginação e o ressentimento, mira e remira a alcova solitária; recorda as amigas do colégio e de família, as mais íntimas, casadas todas. A derradeira delas desposou aos trinta anos um oficial da marinha, e foi ainda o que reverdeceu as esperanças à amiga solteira, que não pedia tanto, posto que a farda de aspirante foi a primeira cousa que Ihe seduziu os olhos, aos quinze anos... Onde iam eles? Mas lá passaram-se cinco anos, cumpriu os trinta e nove, e os quarenta não tardam. Quarentona, solteirona; D. Tonica teve um calafrio. Olhou ainda, recordou tudo, ergueu-se de golpe, deu duas voltas e atirou-se à cama chorando..." 90
\end{abstract}

A abnegação em relação à situação do possível pretendente - "não pedia tanto" - se opõe à atitude interesseira de Sofia em relação a Rubião. Enquanto D. Tonica não consegue um pretendente sequer, a esposa de Palha desfruta do marido, seduz o professor e tenta atrair Carlos Maria. Os trinta anos robustos de Sofia contrastam sobremodo com os quarenta ressequidos da infeliz. Em um único parágrafo, o narrador dá conta de anos de espera e a rima "quarentona, solteirona" reforça, por meio da insistência, o final desventuroso. Para completar a situação desalentadora, na curta estadia no

${ }^{90}$ Quincas Borba, p. 676. 
Rio de Janeiro, a prima do casal Palha, Maria Benedita, conhece e casa-se com Carlos Maria, o mesmo do flerte de outrora com a dona da casa, e quando, finalmente, D. Tonica arranja noivo, um rapaz humilde chamado Rodrigues, ele morre três dias antes das núpcias:

\footnotetext{
"Seis meses, oito meses passam depressa", reflexionou D. Fernanda.

E eles vieram vindo, com os sucessos às costas, - a queda do ministério, a subida de outro em março [...], a morte do noivo de D. Tonica, três dias antes de casar. D. Tonica espremeu as últimas lágrimas, umas de amizade outras de desesperança, ficou com os olhos tão vermelhos que pareciam doentes." ${ }^{91}$
}

A sucessão algo inexorável do tempo e dos fatos narrados, em que reponta inegável dose de ironia, acentua a desgraça da noiva, fazendo com que seja viúva antes mesmo de ter experimentado a vida conjugal. Do mesmo modo, a boa fortuna do casal desonesto - "E eles vieram vindo com o sucesso às costas" - martiriza o destino lastimável da personagem. O casamento, portanto, mais do que institucionalização desejada, é visto como premissa indispensável à socialização e realização femininas em alguns romances machadianos.

\footnotetext{
${ }^{91}$ Quincas Borba, p. 803.
} 
Primeiros tempos em Santa Teresa

Os principais espaços onde ocorrem as atuações iniciais de Sofia, Odette e Madame Verdurin são a casa de Santa Teresa e o salão da Rua Montalivet, embora haja menção às residências de Swann e Odette. No caso de Quincas Borba, a restrição espacial ocorre por causa das limitações das mulheres no que concerne à vida pública. Devendo sempre estar acompanhadas pelos maridos ou por outra figura respeitável, suas atividades ocorriam predominantemente no ambiente doméstico.

As moradias do casal Palha são muito significativas, pois, além de revelarem o progresso da dupla, funcionam como palco das artimanhas de Sofia para com Rubião. Tendo travado conhecimento com o professor no trem de Vassouras, Cristiano, ao descobrir a herança, convida-o a vir jantar com eles. A passagem dessa primeira reunião antecipa o tom a ser estabelecido entre o trio:

\begin{abstract}
"Foi jantar. Abençoada resolução! Onde acharia iguais horas? Sofia era, em casa, muito melhor que no trem de ferro. Lá vestia a capa, embora tivesse os olhos descobertos; cá trazia a vista os olhos e o corpo, elegantemente apertado em um vestido de cambraia, mostrando as mãos que eram bonitas, e um princípio de braço. Demais, aqui era a dona da casa, falava mais, desfazia-se em obséquios; Rubião desceu meio tonto." 92
\end{abstract}

Sofia, intencionalmente sedutora, usa a liberdade de estar em casa para conseguir a simpatia e a confiança de Rubião. Servindo-se de seus atributos físicos como isca, ela, assim como o marido, praticamente transforma o recinto

\footnotetext{
${ }^{92}$ Quincas Borba, p. 660.
} 
familiar em gabinete de trabalho. Inúmeros jantares se sucedem ao primeiro, sempre com a presença do novo companheiro, agora íntimo. Inclusive, a celebração da conclusão do inventário de herança, encabeçado evidentemente por Cristiano, merece celebração especial:

"Palha festejou o acontecimento com um jantar em que tomaram parte, além dos três, o advogado, o procurador e o escrivão. Sofia tinha nesse dia os mais belos olhos do mundo." 93

O feitiço meticuloso de Sofia se faz sentir desde as primeiras páginas da narrativa. Os olhos do trem, antes desatentos, passam a "sublinhar" a fala do mineiro a partir da revelação do inventário, brilhando mais ainda no dia de sua resolução. A associação com a lenda de Santo Antão é igualmente sugestiva:

\footnotetext{
"'Mas que pecado é este que me persegue? Pensava ele andando. Ela é casada, dá-se bem com o marido, o marido é meu amigo, tem-me confiança, como ninguém... Que tentações são estas?'

Parava, e as tentações paravam também. Ele um Santo Antão leigo, diferençava-se do anacoreta em amar as sugestões do Diabo, uma vez que teimassem muito." 94
}

A referência ao santo conecta imediatamente Sofia ao pecado e, por conseguinte, ao diabo. Lembremos as notáveis telas de Bosch do século XV, nas quais a alegoria do demônio é sempre representada por uma bela mulher. $^{95}$ À primeira vista, ela é apenas atraente, mas, ao olharmos atentamente, notamos asas sinistras, caudas ou garras monstruosas. 0

\footnotetext{
${ }^{93}$ Quincas Borba, p. 661.

${ }^{94}$ Idem.

${ }^{95}$ BOSCH, Hieronymus. As tentações de Santo Antão. (1490/1500 e.c.).

(Há uma versão do retábulo central do tríptico no MASP: http://masp.art.br/masp2010/acervo_detalheobra.php?id=992)
} 
narrador alude sutilmente a esse tipo de elemento, de forma que precisamos estar atentos para decifrar seu sentido no texto.

Assim, as investidas de Sofia prosseguem. Vejamos:

"_Quem é que manda isto? Perguntou Rubião.

D. Sofia.

Rubião não conhecia a letra; era a primeira vez que ela Ihe escrevia. Que podia ser? Via-se-lhe a comoção no rosto e nos dedos. Enquanto ele abria a carta, Freitas familiarmente descobria a cestinha: eram morangos. Rubião leu trêmulo estas linhas:

Mando-Ihe estas frutinhas para o almoço, se chegarem a tempo; e, por ordem do Cristiano, fica intimado a vir jantar conosco, hoje, sem falta. Sua verdadeira amiga, Sofia." 96

A simbologia sensual do morango e do bilhete é ressaltada pela insinuação de Carlos Maria:

"Carlos Maria deleitou-se em dizer-Ihe que ele não podia encobrir que o mimo era de alguma namorada. E não achava que repreender; o amor era lei universal [...] O maior pecado, depois do pecado, é a publicação do pecado." 97

Entretanto, a inclusão do nome do marido disfarça o oferecimento de tais prazeres, de modo a manter a moça dentro da moral familiar. Notamos também a vinculação gradativa de Sofia ao universo textual. Vimos que, no trem, seus olhos sublinhavam a confidência de Rubião. Agora o bilhete e sua caligrafia funcionam como uma espécie de materialização da mulher sedutora:

\footnotetext{
${ }^{96}$ Quincas Borba, p. 665.

97 Idem, p. 666.
} 
"Cada palavra dessa página inesperada era um mistério; a assinatura uma capitulação. (...) Rubião viu, sentiu, palpou tudo pela única força do instinto e deu por si beijando o papel, - digo mal, beijando o nome [...] Sofia! Sofia! Sofia!" 98

O "mistério" retoma seu caráter enfeitiçador lembrado com frequência através dos olhos e da lenda cristã. Por outro lado, a adoração de Rubião quase chega à satisfação física, porque há a sensação de possuir a amada através do objeto transmutado na pessoa pelo uso do nome "Sofia". Em seguida, deparamo-nos com outra referência ao fazer literário:

"Agora, [os olhos] mais negros, e já não sublinham nada; compõem logo as cousas, por si mesmos, em letra vistosa e gorda, e não é uma linha nem duas, são capítulos inteiros." 99

A ação dos olhos se torna mais intensa à medida que a promoção do casal aumenta em função das relações com o amigo. Consciente da dependência de seus atributos para manter a proximidade de Rubião, Sofia não se descuida dele, mas o faz com alguma margem de segurança. É importante ressaltarmos que toda a movimentação da personagem se dá no âmbito de sua casa. No seu domínio, ela coopta o provinciano e, sem sair dele, continua agindo ao enviar cartas e agrados. Isso ocorre devido à limitação feminina mencionada anteriormente no que se refere ao espaço. Constatamos a concentração da trama numa esfera muito restrita nos três romances brasileiros. Daí, a importância do bilhete escrito, pois ele permite a

\footnotetext{
${ }^{98}$ Quincas Borba, p. 667.

${ }^{99}$ Idem, p. 668.
} 
continuidade do flerte sem a necessidade da proximidade física, vencendo a distância, quando necessário.

Outra arma não menos importante da qual Sofia lança mão é a moda. Sempre muito bem vestida, tanto em casa quanto na rua, cumpre de forma primorosa sua função de esposa elegante. Os "vestidos caros e joias"100 são tidos como artigos de primeira necessidade dos quais Cristiano não abre mão, mesmo que lhe consuma os "lucros presentes e futuros"101.

"la muita vez ao teatro sem gostar dele, e a bailes, em que se divertia pouco, - mas ia menos por si que para aparecer com os olhos da mulher, os olhos e os seios. Tinha essa vaidade singular; decotava a mulher sempre que podia, e até onde não podia, para mostrar aos outros as suas venturas particulares." ${ }^{102}$

A simbologia da moda, representada pelo decote exagerado, parece, num primeiro momento, corresponder apenas à vaidade extrema de Palha. Contudo, tem grande importância na construção da imagem pública do casal. Dessa maneira, o narrador coloca lado a lado as esferas particular (privada) e pública mostrando-as praticamente misturadas, o que torna o arrivismo atrelado à sedução de Sofia mais insidioso, porque Rubião se configura como o espectador mais fiel de seu encanto. A beleza da vestimenta e do corpo somada ao comprometimento da esposa com o marido (pois, as "venturas" dele são "particulares") produz boa impressão. A esse respeito, tomando como exemplo justamente expressões de Quincas Borba, Gilda de Mello e Souza comenta:

\footnotetext{
${ }^{100}$ Quincas Borba, p. 666.

${ }^{101}$ Idem.

${ }^{102}$ Idem, p. 669.
} 
"O encanto feminino e a determinação masculina não se excluem mutuamente; na verdade, são parcelas que se somam na contabilidade astuciosa da ascensão. A graça de trazer o vestido, de exibir no baile os braços e ombros, fazendo-os melhores "por meio de atitudes e gestos escolhidos", é simétrica ao talento e ambição exigidos pela carreira." ${ }^{103}$

Notemos também a insistência do narrador no aspecto público do sucesso representado metonimicamente pelas partes do corpo da mulher "olhos" e "seios". O prazer da posse do corpo simboliza e acompanha a satisfação da detenção monetária. No caso da obra, o público é sobretudo Rubião, que concorre com o dinheiro, mas não possui a mulher. Assim, os recursos financeiros mudam de mãos facilmente, pois Palha obtém os bens materiais sem ter de abrir mão da parceira.

Em $A$ mão e a luva e Helena, as heroínas trazem força nova pelo simples fato de apoiarem seus pares. Em Quincas Borba, Sofia vai além, participando ativamente do agenciamento da vítima planejado pelo cônjuge. Mas ela o faz preservando as aparências. Decide, junto ao marido, manter a amizade com Rubião, mesmo após a declaração de amor explícita feita no jardim de sua própria casa, às vistas dos convidados num dos muitos jantares oferecidos pelo casal: "Ainda bem que te não zangas; mas é preciso trancar-lhe a porta, - ou de uma vez ou aos poucos - eu preferia logo, mas estou por tudo." 104 Aqui, o discurso vai se atenuando da firmeza total à concessão: a frase "mas estou por tudo" faz desabar as afirmações anteriores.

${ }^{103}$ SOUZA, Gilda de Mello e. O espírito das roupas. A moda no século dezenove. São Paulo: Companhia das Letras, 1987, p. 83.

${ }^{104}$ Quincas Borba, p. 683. 
Além disso, ao optar pelo diálogo, o narrador parece não interferir na narrativa, aproximando, de modo completo, as personagens do leitor. Desse modo, a nuance final ("estou por tudo") funciona também como confirmação do acordo das vontades do casal e vai de par com a exposição do corpo de Sofia.

Voltando à questão da residência atual do casal Palha, observamos tratar-se de local adequado, mas, ainda, modesto. Santa Teresa, não era, à época, um dos bairros elegantes do Rio de Janeiro. A região mais cobiçada era, naturalmente, a zona sul e seus casarões. O diálogo abaixo entre o par revela, igualmente, a simplicidade de suas recepções bem como dos convidados:

" A nossa festa esteve bem bonita, disse ele.

- Esteve.

- O Siqueira é um cacete, mas paciência; é alegre. A filha não estava mal arranjada. Viste o Ramos como devorava tudo o que se lhe pôs no prato? Tu verás que ele um dia engole a mulher." 105

Embora Sofia confirme a beleza da festa, a crítica seguinte de Cristiano a todas as pessoas contradiz tal asserção. Vemos uma sucessão de figuras cujo pertencimento social passa longe da elite. Siqueira, aquele simples major, pai de D. Tonica, a solteirona, é inconveniente e opinativo a ponto de ser constrangedor. A filha infeliz "aprimora os trastes modestos e poucos". ${ }^{106}$ Por fim, Ramos demonstra os piores modos possíveis à mesa.

Essas reuniões, no entanto, têm como função começar a preparar Sofia e Cristiano Palha na arte de receber e de portar-se. A compreensão gradual

\footnotetext{
${ }^{105}$ Quincas Borba, p. 682.

${ }^{106}$ Idem, p. 676.
} 
das regras sociais tem início ali, na casa de Santa Teresa. Do mesmo modo, o salão de Madame Verdurin, na Rua Montalivet, será o ambiente das primeiras empreitadas da dona da casa, assim como as de sua fiel frequentadora, Odette de Crécy. Passemos a ele.

O salão da rua Montalivet

Em À la recherche du temps perdu, Odette está ao lado de Madame Verdurin, tanto na primeira quanto na última recepção oferecidas por esta, dentre as várias retratadas no romance. A apresentação das duas personagens ocorre de forma paralela no salão da Rua Montalivet, em Du côté de chez Swann, assim como a análise conclusiva de seus percursos, feita pelo narrador na matinée final de Le Temps retrouvé.

Em Proust, os lugares são quase extensões dos seres, pois se integram de maneira inconteste às figuras que os ocupam. A esse respeito, Georges Poulet comenta:

"Les êtres s'entourent des lieux où ils se découvrent, comme on s'enveloppe d'un vêtement qui est en même temps un déguisement et une caractérisation. Sans les lieux, les êtres ne seraient que des abstractions. Ce sont les lieux qui précisent leur image, et qui nos donnent ainsi le support nécessaire, grâce auquel nous pouvons leur assigner une parole dans notre espace mental, rêver d'eux et nous souvenir d'eux." 107

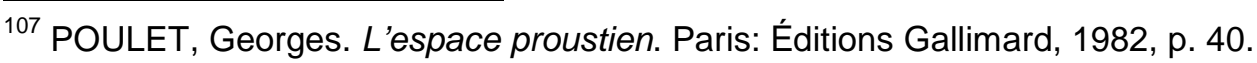


Transitaremos por diversos salões, burgueses e aristocráticos, ao longo desta leitura. Para tanto, optamos por analisá-los separando-os pelos blocos temporais dados pela própria narrativa. Neste capítulo, vamos nos ocupar do salão de estreia dos Verdurin, do apartamento de Odette e do Hôtel da marquesa de Saint-Euverte como contraponto aos dois primeiros. Observemos, então, como tais espaços se constituem.

Podemos dizer que a construção de Madame Verdurin é indissociável da constituição do seu salão. Ele é uma extensão dela e a evolução progressiva da personagem ocorre simultaneamente ao desenvolvimento de seu espaço social no mundo, ou seja, o lugar que ocupa no ambiente mundano. A primeira frase do parágrafo inicial de "Un amour de Swann" traz, antes mesmo de nos dar informações acerca da personagem, o petit noyau de Madame Verdurin, formado por seus fiéis frequentadores. Toda a caracterização do núcleo se compõe de expressões paródicas referentes à religião: il fallait adhérer à un Credo, l'orthodoxie de la petite église ${ }^{108}$, para transmitir a ideia de um círculo fidelizado. ${ }^{109}$ Isso ocorre porque Madame Verdurin não tem trato social condizente com suas ambições.

Nesse meio, estabelece-se um sistema de deveres e obrigações de ambos os lados. Ela oferece entretenimento artístico em troca da assiduidade

\footnotetext{
${ }^{108}$ Du côté de chez Swann, p. 185.

109 KRISTEVA, Julia. Le temps sensible. Proust et l'expérience littéraire. Paris: Éditions Gallimard, 1994, p. 80: "Qu'est-ce qu'un clan? _ Un isolement du sens, une parole qui se protège des autres, souvent enviés, et qui n'est transparente qu'aux "intimes", "convives" ou "initiés".
} 
dos convidados. ${ }^{110}$ Atentemos também à insignificância dos que lá frequentam: Dr. Cottard, um médico desconhecido e sua esposa; um pianista cujo nome não é nem mesmo mencionado e sua tia, uma zeladora de prédio; o pintor Biche antes de tornar-se o vanguardista Elstir; um inautêntico professor da Sorbonne chamado Brichot; e a demi-mondaine Madame de Crécy. Assim como o casal Palha, Madame Verdurin não está em posição de escolher quem frequenta suas quartas-feiras, devendo contentar-se com quem se dispõe a ser assíduo e conivente com seus ideais.

Se o texto é paródico em relação a termos religiosos, é satírico em seu ataque ao nível social e ao anonimato dos convivas de tais recepções. Apesar de se pretender exclusivo, seu salão não parece ser nem tão fechado, nem tão protegido, pois pode ser visitado por "qualquer um" que se disponha a fazê-lo regularmente.

Após apresentar os integrantes do petit noyau, o narrador ressalta a escassez de frequentadores. Vejamos o trecho em questão:

"En dehors de la jeune femme du docteur, ils étaient réduits
presque uniquement cette année-là (bien que Madame
Verdurin fût elle-même vertueuse et d'une respectable famille
bourgeoise excessivement riche et entièrement obscure avec
laquelle elle avait peu à peu cessé volontairement toute
relation) à une personne presque du demi-mode, Madame de
Crécy, que Madame Verdurin appelait par son petit nom,
Odette, [...]; personnes ignorantes du monde et à la naiveté de
qui il avait été si facile de faire accroire que la princesse de

${ }^{110}$ HUGHES, Edward. "Poust and social spaces" in BALES, Richard (ed.), op. cit., p. 154: "By associating the social with the religious - the Credo implies a code of binding social practices, obligations and beliefs, and indeed the Narrator refers to the orthodoxy of the little church Proust sees the classification and hierarchy that are intrinsic to the workings of the Verdurin salon." 
Sagan et la duchesse de Guermantes étaient obligées de payer des malheureux pour avoir du monde à leurs dîners, que si on leur avait offert de les faire inviter chez ces deux grandes dames, l'ancienne concierge et la cocotte eûssent dédaigneusement refusé." 111

Ao contrário dos salões mundanos como tantos da obra, o de Madame Verdurin se caracteriza por anonimato, baixa extração social e número reduzido de convidados se comparado com a longa exposição de nomes e títulos presentes na festa do príncipe de Guermantes.

A dimensão social do salão pode ser percebida através do conjunto de expressões com sentido de pequenez - réduits, demi-monde, petit nom - e de alienação - ignorantes, naiveté, si facile de faire accroire. Por outro lado, o contraste com grandes nomes (da princesa de Sagan e da duquesa de Guermantes) ressalta ainda mais o caráter diminuto daquele espaço, opondo títulos de nobreza a condições de obscuridade social (zeladora, pintor desconhecido, médico iniciante, família completamente irrelevante). Os nomes Sagan e Guermantes valem por si mesmos do ponto de vista social.

Nessas noites, sempre às quartas-feiras, os Verdurin reúnem esse pequeno grupo para ouvir música em torno da mesa, posta de maneira deliberadamente informal, assim como o jeito de vestir-se:

"Les Verdurin n'invitaient pas à dîner: on avait chez eux 'son couvert mis'. Pour la soirée, il n'y avait pas de programme. [...] L'habit noir était defendu parce qu'on était entre 'copains' et pour ne pas ressembler aux 'ennuyeux' dont on se garait comme la peste et qu'on n'invitait qu'aux grandes soirées, données le plus rarement possible et seulement si cela pouvait

${ }^{111}$ Du côté de chez Swann, pp. 185, 186. 
amuser le peintre ou faire connaître le musicien. Le reste du temps on se contentait de jouer des charades, de souper en costumes, mais entre soi, en ne mêlant aucun étranger au petit 'noyau'."

A aparente descontração no modo de servir os convidados e a insistência no traje casual revelam muito mais a falta de savoir-faire da Patronne que uma repulsa aos salões nobres. Como ela não conta com ninguém de renome para abrilhantar suas noites, investe no talento de jovens artistas para divertir seus convidados. Segundo Julia Kristeva, a separação rigorosa entre "nós" e os "outros" decorre do "espírito binário" da personagem ao excluir todos que não se juntam a ela. ${ }^{112}$ Ora, esse procedimento é fundamental na progressão social do núcleo, pois estimula a confiança e o crescimento individual, fatores cruciais no futuro reconhecimento das qualidades do salão. Além disso, sabemos que, após consolidar-se como uma das mulheres mais influentes de Paris, a atitude de dividir os grupos será substituída pela postura unificadora da futura princesa de Guermantes, a exemplo da soirée final integrada por representantes de meios variados.

Concomitantemente à continuação do desvelamento do salão Verdurin, o narrador inclui no enredo os primórdios do relacionamento entre Odette de Crécy e Charles Swann. Tendo sido apresentada a ele por um amigo no teatro, Odette empenha-se para conseguir aproximar-se do promissor pretendente. Após esse primeiro encontro, assistimos às insistentes investidas dela:

\footnotetext{
112 KRISTEVA, Julia, op. cit., p. 80: "La Patronne procède par exclusion et son esprit est binaire: les "habitués" sont des intelligents qui s'opposent aux "ennuyés" lesquels sont banis."
} 
"Quelque temps après cette présentation au théâtre, elle lui avait écrit pour demander à voir ses collections qui l'intéressaient tant, «elle ignorante qui avait le goût des jolies choses», disant qu'il lui semblait qu'elle connaîtrait mieux, quando elle l'aurait vu dans «son home» où elle imaginait «si confortable avec son thé et ses livres», quoiqu'elle ne lui eût pas caché sa surprise qu'il habitait ce quartier qui devait être si triste et «qui était si peu smart pour lui qui était tant»." 113

Se o bilhete de Sofia a Rubião indica uma sedução velada, a correspondência de Odette se caracteriza pelo tom direto. Em um único texto, Madame de Crécy deixa transparecer muitas de suas intenções. A vontade de conhecer a coleção de arte é apenas pretexto para obter uma entrevista íntima. Ser recebida no conforto da privacidade de Swann entre seus livros e seu chá sugere mais que puro interesse intelectual. A aproximação física tem caráter sexual evidente. Além disso, Odette não se furta de criticar o bairro habitado por Swann, deixando escapar, indiretamente, sua insatisfação perante a possibilidade de morar na região. A Île Saint-Louis não era uma região elegante à época, mas considerada como reduto de artistas, o que faz com que a presença de um diletante como Swann, mais interessado na simbologia do que no status do local, seja perfeitamente pertinente. Outras duas vezes, o narrador insiste em tal desaprovação quando ela lhe revela que considera o Quai d'Orléans indigno dele e seus móveis e tapetes antigos de extremo mau gosto. ${ }^{114}$ A ignorância de Odette não a deixa apreciar peças de valor histórico; somente o que está em voga agrada seu olhar, como veremos em seu

\footnotetext{
${ }^{113}$ Du côté de chez Swann, p. 193.

${ }^{114}$ Idem, pp. 240, 241.
} 
apartamento da Rua de La Pérouse e, posteriormente ao casamento, na residência da Avenida do Bois de Boulogne, já como Madame Swann. ${ }^{115}$

O narrador usa o artifício de misturar o discurso indireto com trechos da mensagem, que revelam a busca da intimidade, o pedantismo dos termos ingleses e a incapacidade de julgamento estético. Tudo se amolda ao perfil de Odette, a qual se coloca, ao mesmo tempo, como alguém que tem algo a oferecer (companhia e corpo) e algo a receber (cultura e posição social). A possível ascensão se mostra evidenciada e só fará aumentar ao longo da obra; o corpo se fará presente (gravidez, maternidade, amantes) em correlação com a vida social ascendente.

Nos primeiros tempos do relacionamento entre Odette e Swann, assistimos à alternância entre a insistência dela e a hesitação dele, mas, por fim, a persistência e disponibilidade de Madame de Crécy - Moi, je n'ai jamais rien à faire! Je suis toujours libre pour vous. À n'importe quelle heure ${ }^{116}$ - se sobressaem, convencendo-o a juntar-se a ela e ao clã Verdurin. Por outro lado, a caracterização de Odette se constrói aos poucos, de forma que a sucessão de pequenos elementos acaba por compor a figura. Essa maneira de apresentar a personagem cria uma aura de encantamento ao seu redor, tornando-a ainda mais atraente na percepção de Swann, o que se percebe na gradação do interesse pela cocotte expressa na narrativa.

\footnotetext{
${ }^{115}$ SAIKI, Shinichi. Paris dans le roman de Proust. Paris: Éditions SEDES, 199, p. 22: "Odette [...] reste ainsi aveugle aux signes de l'authenticité culturelle. Par contre, 'les endroits chics' sont, d'après Odette, 'le dimanche matin, l'avenue de l'Impératrice, à cinq heures le tour du Lac, le jeudi l'Eden Théâtre, le vedredi l'Hippodrome', c'est que les endroits aimés par Odette, comme pour faire contraste avec le Quai d'Orléans, sont aussi neufs qu'éphémères [...]" ${ }^{116}$ Du côté de chez Swann, pp. 195, 196.
} 
Para ser apresentado aos amigos de Odette, Swann recorre ao avô de Marcel. Nesse momento, o narrador aproveita para adicionar à descrição dos Verdurin outro ponto de vista, o de sua própria família:

\begin{abstract}
"Mon grand-père avait précisément connu [...] la famille de ces Verdurin [...] qu'il appelait le "jeune Verdurin" et qu'il considérait, un peu un gros, comme tombé - tout en gardant de nombreux millions - dans la bohème et la racaille. Un jour il reçut une lettre de Swann lui demandant s'il ne pourrait pas le mettre en rapport avec les Verdurin: "À la garde! À la garde! s'était écrié mon grand-père, ça ne m'étonne pas du tout, c'est bien par là que devait finir Swann. Joli milieu!" 117
\end{abstract}

Aqui, temos a confirmação da vulgaridade dos Verdurin. Sendo o núcleo familiar do narrador o mais respeitável e ponderado da Recherche $^{118}$, sua chancela reitera o desmerecimento do círculo. Nesse sentido, constatamos que fortuna sem tradição não alcança o reconhecimento dentre as camadas mais altas, pelo menos por enquanto. Outro dado significativo é a antecipação feita pelo avô do que seria o futuro de Swann ao referir-se ironicamente àquele joli milieu. Embora vá ser banido do grupo posteriormente por não se enquadrar nele, Swann, frequentador da mais alta roda do faubourg Saint-Germain, terá sua vida social bastante comprometida ao casar-se com Odette.

A descrição do espaço físico do salão Verdurin ocorre na primeira visita de Swann:

"Mme Verdurin était assise sur un haut siège suédois en sapin ciré, qu'un violoniste de ce pays lui avait donné et qu'elle

\footnotetext{
${ }^{117}$ Du côté de chez Swann, p. 196.

${ }^{118}$ GENETTE, Gérard. "Proust Palimpsesto" in Figuras. São Paulo: Perspectiva, 1972. p. 55: "Com exceção da família do Narrador, que encarna, entre outros valores, uma espécie de nostalgia da estabilidade, quase todas as personagens da Recherche são proteiformes."
} 
conservait, quoiqu'il rappelât la forme d'un escabeau et jurât avec les beaux meubles anciens qu'elle avait, mais elle tenait à garder en évidence les cadeaux que les fidèles avaient l'habitude de lui faire de temps en temps, afin que les donateurs eussent le plaisir de les reconnaître quand ils venaient.[...]" 119

Swann, com intenção de agradar a anfitriã, não poupa elogios à mobília, embora esteja absorvido pela presença de Odette e pelo recital da sonata de Vinteuil. Notamos a excentricidade da decoração com os bibelôs e o fato de estar sentada acima dos convidados, reafirmando sua função de autoridade espiritual perante os mesmos e a caracterização de seita religiosa mencionada anteriormente. Toda a cena é hilariante, pois a Patronne é vista como se estivesse em um poleiro como um pássaro. Em momento algum, Madame Verdurin deixa de demonstrar, aos olhos do narrador, certa inadequação social. Isso é indicado já nas primeiras cenas em que aparece, pois é descrita como autoritária, invejosa, insegura e desconhecedora das regras e genealogias aristocráticas.

Do mesmo modo, a integração dos móveis de diversos estilos ao seu altar de presentes não faz pensar em ecletismo estético, mas num bazar arranjado sem o menor critério. Nesse tipo de cena, na qual o recinto é referido como uma extensão da personagem, percebemos a filiação balzaquiana de Proust ao relembrarmos o início de Le père Goriot. Assim como Madame Vauquer não pode ser concebida sem sua pensão, Madame Verdurin não existe sem o espaço que a cerca; em ambos os casos, os seres e os elementos que os circundam são indissociáveis. Apesar da semelhança, a

\footnotetext{
${ }^{119}$ Du côté de chez Swann, p. 202.
} 
personagem de Balzac não sai de seu meio e sua casa é o resultado comercial e social de seu enraizamento. Sabemos que o mesmo não ocorre com Verdurin, pois ela será protagonista do arrivismo mais espetacular da Recherche.

Quanto a Odette de Crécy, ela atua em dois campos: no público e social, no domínio dos Verdurin, e na intimidade de seu apartamento da Rua de La Pérouse. A casa decorada com ecletismo, misturando lanternas japonesas, palmeiras, vasos e louças chinesas, revela o gosto da cocotte, afeita às modas em voga, dentre elas a febre orientalista, sem preocupar-se minimamente com o valor histórico das peças. Outro fator relevante é a localização estratégica do imóvel, acessível por duas ruas perpendiculares e escadas independentes. Tal configuração permite que Odette, sendo uma femme entretenue, consiga livrarse de possíveis constrangimentos, caso receba visitas simultâneas, o que acontecerá justamente com Swann e Forcheville, outro amante do qual falaremos no último capítulo.

Durante todo o período que antecede o casamento, a natureza do relacionamento se baseia nos interesses sociais e financeiros por parte dela; 0 afeto é proporcional aos benefícios materiais obtidos:

\footnotetext{
"En effet, si ce mois-ci il venait moins largement à l'aide d'Odette dans ses difficultés matérielles qu'il n'avait pas fait le mois dernier où il lui avait donné cinq mille francs, et s'il ne lui offrait pas une rivière de diamants qu'elle désirait, il ne renouvellerait pas en elle cette admiration qu'elle avait pour sa générosité, cette reconnaissance, qui le rendaient si heureux, et même il risquerait de lui faire croire que son amour pour elle, comme elle verrait les manifestations devenir moins grandes, avait diminué."120
}

\footnotetext{
${ }^{120}$ Du côté de chez Swann, p. 264.
} 
Através do discurso indireto, apreendemos o poder persuasivo de argumentação e convencimento da personagem para conseguir o que quer. Associando diretamente o valor dos presentes e do dinheiro à intensidade de amor demonstrada a ele, Odette consegue manter a constância de tais agrados. Por outro lado, não podemos deixar de mencionar que, apesar de admirar a posição de Swann no grand monde, Odette não pretende se restringir a tal meio, mesmo porque, inicialmente, ela não pode frequentá-lo. Madame de Crécy quer ascender, mas sua ideia de chique, contrariamente à noção de exclusividade prezada pela aristocracia, era ser popular em todos os setores da sociedade parisiense:

"D'ailleurs ce monde [...] ne lui inspirait peut-être pas de grands désirs, car pour qu'elle se le représentât bien nettement, il était trop éloigné de celui qu'elle connaissait. Pourtant, tout en étant restée à certains égards vraiment simple (elle avait par exemple gardé pour amie une petite couturière retirée dont elle grimpait presque chaque jour l'escalier raide, obscur et fétide), elle avait soif du chic, mais ne s'en faisait pas la même idée que les gens du monde. Pour eux, le chic est une émanation de quelques personnes peu nombreuses qui le projettent jusqu'à un dégré assez éloigné [...] dans le cercle de leurs amis ou des amis de leurs amis dont les noms forment une sorte de répertoire. Mais Odette faisait partie des personnes [...] d'être directement accessible à tous." ${ }^{121}$

Nessa passagem, o narrador faz uma explanação do tipo de ascensão almejado por Odette em oposição aos hábitos restritivos da nobreza. Sua busca por um reconhecimento que transborde a alta roda elitista, divergente do estilo da duquesa de Guermantes, será consolidada ao final da obra.

\footnotetext{
${ }^{121}$ Du côté de chez Swann, p. 239.
} 
Em "Un amour de Swann", a maior parte do texto é dedicada à exposição dos espaços de Madame Verdurin e Odette de Crécy. Por isso mesmo, na parte final dessa novela, temos, como um claro contraste, a descrição da recepção no Hôtel da marquesa de Saint-Euverte, o primeiro aristocrático apresentado na obra.

Depois de ser banido do clã Verdurin pelo fato de recusar-se a concordar com as opiniões equivocadas da dona da casa a respeito de figuras reconhecidamente cultas e elegantes do faubourg Saint-Germain ${ }^{122}$, Swann decide ir à noite festiva organizada por Saint-Euverte. O momento de sua chegada à propriedade causa grande impacto, devido à grande discrepância entre os ambientes socialmente irrelevantes visitados por ele nos últimos tempos e o rigor de um evento que preza as convenções:

\begin{abstract}
"Dès sa descente de voiture, au premier plan de ce résumé ficitf de leur vie domestique que les maîtresses de maison prétendent offrir à leurs invités les jours de cérémonie et où elles cherchent à respecter la vérité du costume et celle du décor, Swann prit plaisir à voir les héritiers des "tigres" de Balzac, les grooms, suivants ordinaires de la promenade, qui, chapeautés et bottés, restaient dehors devant l'hôtel [...].

[...] pour la première fois il remarqua, réveillée par l'arrivée inopinée d'un invité aussi tardif, la meute éparse, magnifique et désouvrée des grands valets de pied [...] soulevant leurs nobles profils aigus [...].
\end{abstract}

${ }^{122}$ Somente após ser excluído do clâ Verdurin, Swann, enraivecido, revê sua opinião a respeito de tal salão e traz à tona o comportamento questionável de Madame Verdurin em comparação a certa dama aristocrática: "C'est vraiment, disait-il, ce qu'il y a de plus bas dans l'échelle sociale [...] Les gens du monde ont leur défauts que personne ne reconnaît mieux que moi [...]. Telle femme élégante que j'ai connue était loin d'être parfaite, mais enfin il y avait tout de même chez elle un fonds de délicatesse, une loyauté dans les procédés qui l'auraient rendue, quoi qu'il arrivât, incapable d'une félonie et qui suffisent à mettre des abîmes entre elle et une mégère comme la Verdurin!", Du côté de chez Swann, p. 283. 
D'autres encore, colossaux aussi, se tenaient sur les degrés d'un escalier monumental que leur présence décorative et leur immobilité marmoréenne auraient pu faire nommer comme celui du Palais ducal: "l'Escalier des Géants" [...]. Ah! Avec quelle joie au contraire il eût grimpé les étages noirs, malodorants et casse-cou de la petite couturière [...]" ${ }^{123}$

A ênfase na importância da preservação dos costumes tradicionais se opõe frontalmente à familiaridade exigida no salão Verdurin. A elegância dos empregados, plenamente acordados à maneira formal de vestir-se para receber os convidados em noites cerimoniosas, contrasta com a informalidade dos habitués do pequeno salão burguês, no qual o uso da casaca estava proibido. O termo tigres, usado por Balzac para denominar os pajens dos nobres mais elegantes, revela a insistência na manutenção de hábitos caros à aristocracia. $^{124}$ Nessa concordância com as regras estabelecidas e aprimoradas durante séculos, até mesmo os domésticos adquirem compostura e feições nobres. Na sequência, Swann reencontra-se com alguns conhecidos: general Froberville, membro do Jóquei Clube; Monsieur de Breauté, um marquês; Madame de Gallardon, uma maquesa; e, por fim, a princesa de Laumes, futura duquesa de Guermantes, dama a ocupar a posição mais

\footnotetext{
${ }^{123}$ Du côté de chez Swann, pp. 317-319.

${ }^{124}$ Proust retoma tal expressão da novela Les secrets de la princesse de Cadignan, de Balzac: "Le tigre du duc avait alors un service un peu rude. Toby, l'ancien tigre de feu Beaudenord, car telle fut la plaisanterie du beau monde sur cet élégant ruiné, ce jeune tigre qui, à vingt-cinq ans, était toujours censé n'en avoir que quatorze, devait suffire à panser les chevaux, nettoyer le cabrioler ou le tilbury, suivre son maître, faire les appartements, et se trouver à l'antichambre de la princesse pour annoncer, si par hasard elle avait à recevoir la visite de quelque personnage", La Comédie Humaine, Bibliothèque de La Pléiade, 1936, vol. VI, p. 15. (Proust já havia usado esse termo no seu pastiche de Balzac em Pastiches et mélanges.)
} 
respeitada no faubourg Saint-Germain. ${ }^{125}$ Fica clara, nessa enumeração de personagens de ascendência nobiliária, a alusão - por oposição - à insignificância dos fieis frequentadores do salão Verdurin. Aqui, a necessidade da nomeação dos títulos explica o tipo de núcleo no qual Swann está inserido, enquanto, no círculo burguês, o desconhecimento público dos nomes lá presentes indica sua irrelevância perante as classes elevadas.

Das diferenças do domínio de Madame Verdurin, passamos à comparação com o meio pelo qual circula Odette. A clareza referida pela imagem da imponente escadaria de mármore ressalta a imundície dos pequenos degraus percorridos diariamente por Madame de Crécy. Igualmente, a contraposição dos termos monumental e casse-cou amplifica a conotação de ambos, de maneira que aquele pareça ainda maior e este intensifique a impressão da falta de espaço das escadas da casa da costureirinha. Enfim, o retorno de Swann ao círculo mundano, após um longo intervalo dedicado inteiramente a Odette revela, a um só tempo, ao esteta e ao leitor, o panorama do modo de organização dos dois núcleos sociais retratados mais amplamente na obra. Inicialmente incomunicáveis, esses universos iniciarão lento e progressivo diálogo até a completa subversão das rígidas regras estabelecidas.

Tentamos abordar, neste capítulo, o empenho inicial das personagens para modificarem sua situação social e se transferirem para um patamar mais elevado. Guiomar e Helena não desperdiçam a grande oportunidade de estabelecer-se junto a famílias abastadas e se esforçam como podem para que a adaptação seja perfeita. Sofia empreende com o marido o projeto de ascensão à custa da ingenuidade de Rubião, ao mesmo tempo em que exercita

${ }^{125}$ Du côté de chez Swann, pp. 321-325. 
a função de anfitriã nos modestos jantares em Santa Teresa. No contexto francês, muito mais estratificado que o brasileiro, Madame Verdurin precisa ser agressiva na busca de um lugar de destaque, visto que a organização da sociedade representada na Recherche é extremamente regulada e exclusivista. Por sua vez, Odette de Crécy visa, no casamento com Swann, a melhor oportunidade de conquistar a elegância que deseja, não medindo esforços para seduzi-lo.

Todos os exemplos demonstram o descontentamento com o presente e o esforço para construir um futuro diferente. Nossa intenção, por enquanto, foi tentar expor a gênese das diferentes ambições e delinear as particularidades de tais construções, evidentemente díspares de uma literatura para outra. Contudo, a discrepância entre o periferismo da sociedade fluminense na segunda metade do século XIX e a relevância de Paris da Belle Époque no ocidente, como relatados em Machado e Proust, não impede estabelecer pontes entre os textos selecionados no que se refere ao tema universal do projeto de arrivismo social. 


\title{
Capítulo III
}

\section{Transições}

Le renom d'habileté vient souvent de maladresses dont on a su tirer parti.

Henri de Régnier ${ }^{126}$

Guiomar e a questão da escolha

\begin{abstract}
"Ao mesmo tempo que ia provando os sentimentos de seu coração, revelava a moça, não menos, a plena harmonia de seus instintos com a sociedade em que entrara. A educação, que nos último tempos recebera, fez muito, mas não fez tudo. A natureza incumbira-se de completar a obra, - melhor diremos, começá-la. Ninguém adivinharia, nas maneiras finamente elegantes daquela moça, a origem mediana que ela tivera; a borboleta fazia esquecer a crisálida." 127
\end{abstract}

A passagem acima marca a transição da adaptação inicial de Guiomar ao cotidiano do meio que a acolheu. O texto faz um resumo explicativo do que se passou e aponta o rumo do que está por vir. Notemos a recorrente insistência na associação entre o natural e o social. Ao destacar o casamento perfeito entre instinto e diligência, o sinuoso narrador suaviza o possível caráter puramente arrivista da heroína. A dedicação extremosa à madrinha é sempre descrita com dois sentidos: o cálculo e o afeto verdadeiro. À primeira vista

\footnotetext{
${ }^{126}$ RÉGNIER, Henri de. Donc. Paris: Éditions du Sagittaire, 1927, p. 46.

${ }^{127}$ A mão e a luva, p. 218.
} 
opostas, tais conotações divergentes exercem funções complementares no texto.

Temos visto que a tônica da narrativa se dá exatamente nessa alternância. A "plena harmonia" da personagem de origem humilde com a elite pode ser constatada em todos os instantes, pois é natural, como sugere o conjunto de termos escolhidos: os instintos, a natureza, a borboleta. Não há, portanto, embate, mas integração. Mais trabalhoso será, no entanto, atender aos anseios dos sentimentos em relação ao amor conjugal. Se o afeto para com a baronesa, apesar de parecer deliberado, é percebido também como verdadeiro pelo leitor, pois preenche uma lacuna no relacionamento de mãe e filha por parte de ambas, a satisfação do sentimento matrimonial não é colocada de maneira simples, porque, além de serem apresentados três pretendentes, o escolhido deve, evidentemente, agradar a matriarca. Veremos como Guiomar se movimenta entre as três opções, devendo ser habilidosa também com a madrinha e Mrs Oswald. Atentemos à organização do texto.

No decorrer da obra, Mrs Oswald atua como uma espécie de mantenedora do status quo, buscando atender os interesses da baronesa e de si própria. Funciona, à maneira de José Dias, em Dom Casmurro, como anteparo social às investidas arrivistas (Guiomar e Capitu). Assim como Capitu, Guiomar usará de seu encanto pessoal, carinho natural e a perfeita consciência do papel social para equilibrar-se entre os pretendentes, as expectativas da inglesa e o poder da baronesa. ${ }^{128}$

\footnotetext{
${ }^{128}$ A esse respeito ver a análise de José Dias feita por Gilberto Pinheiro Passos em seu Capitu e a mulher faltal. Análise da presença francesa em Dom Casmurro. São Paulo: Nankin Editorial, 2003, pp. 43-46.
} 
Em posição menos privilegiada que a da afilhada, já que não pode simular um pertencimento familiar propriamente dito, Mrs Oswald trabalha para garantir um espaço naquele núcleo. A maioria dos diálogos da fase intermediária que privilegia a escolha do noivo será entre ela e Guiomar, certamente porque há a possibilidade de uma franqueza maior, estando ambas abaixo da proprietária. As discussões com esta última serão sempre pontuais e cuidadosas, para que nunca seja minimamente contrariada. Falaremos disto mais adiante. Por enquanto, tratemos da governanta e dos pretendentes.

O romance se abre com uma caracterização pormenorizada de Estêvão, o primeiro. Tendo o rapaz e a protagonista travado conhecimento anteriormente, reencontram-se na divisa das casas de Luís Alves, advogado vizinho da baronesa e amigo de faculdade daquele. Sua caracterização romântica e idealista se opõe explicitamente ao perfil de Guiomar. As primeiras reflexões da moça acerca das possibilidades de casamento, questão primordial do romance, decorrem da insistência de Estêvão em se aproximar dela. Os avanços desastrados do jovem são, desde o ponto de partida, estéreis. Servem, contudo, para trazer à tona o assunto do amor e do casamento, ao mesmo tempo em que, por contraste, delineia-se melhor o caráter altivo de Guiomar. Em seguida, aparece também Jorge, sobrinho da baronesa e possível segunda opção que, do mesmo modo, não contempla os anseios da moça. Toda a movimentação será acompanhada atentamente pela governanta. Após visita deste último à casa, temos um diálogo entre elas e alguns comentários do narrador: 
“_ [...] Olhe, da senhora posso eu jurar que não está namorada de pessoa alguma.

- Que sabe disso? perguntou Guiomar deitando os olhos para o espelho de seu guarda-vestidos. Pois estou, mas de mim mesma. [...]

A senhora é a flor desta sua terra. Quem a colherá? Alguém sei eu que a merece... [...]

Não era a primeira vez que Mrs Oswald aludia a alguma cousa que desagradava a Guiomar; nem a primeira que esta Ihe respondia com sequidão [...]

Não estou zangada, acudiu prontamente Mrs Oswald. Zangada por quê? Pesa-me, decerto, que a natureza me não dê razão, e que uma aliança tão conveniente, para ambos, seja repelida pela senhora; mas se isto é motivo de desgosto, não pode sê-lo de zanga [...]

_ Desgosto?

- Para mim... e naturalmente para ele.

Guiomar respondeu com um simples sacudir de ombros, seco e rápido [...] A moça, entretanto, pareceu arrepender-se daquele movimento; travou das mãos da inglesa, e com uma voz ainda mais doce e macia que de costume lhe disse:

_ Veja o que é ser criança!" 129

Durante a sequência de acontecimentos relativos ao aparecimento de Estêvão, Jorge e Luís Alves, a personagem com quem Guiomar mais dialoga é Mrs Oswald. A governanta procura direcioná-la de acordo com a vontade da baronesa, mas ela recusa, habilmente, esse tipo de controle. No início do diálogo, percebendo que a moça não corresponde ao sentimento de Estêvão, a agregada aproveita a ocasião para introduzir o assunto da aliança com Jorge, tampouco interessante à jovem.

O trecho acima revela também o grande amor próprio de Guiomar e o sentimento de superioridade em relação a Mrs Oswald, pois a considera "inferior e mercenária". ${ }^{130} \mathrm{O}$ mais importante, contudo, é a alternância de comportamento da afilhada para com a funcionária. Do ar de "desagrado" e

\footnotetext{
${ }^{129}$ A mão e a luva, pp. 221, 222.

${ }^{130}$ Idem, p. 222.
} 
"sequidão", ela passa rapidamente a uma atitude arrependida e afetuosa. Da postura algo particular e narcisista ao afirmar que está namorada de si mesma, transforma-se repentinamente em dócil menina. Tal intercalação de posturas divergentes parece ecoar a voz narrativa que lança mão desse artifício o tempo todo, como se a constituição da personagem se baseasse justamente nos contrastes. Esse procedimento textual vai ao encontro do estatuto ficcional do agregado, representado pelo comportamento melindroso tanto de Guiomar quanto de Mrs Oswald.

Nos capítulos intermediários que se seguem, o leitor acompanhará a apresentação de Jorge, uma breve retomada do romântico Estêvão e a exposição inicial do perfil de Luís Alves. A partir da insinuação de Mrs Oswald do merecimento de Guiomar por Jorge, o narrador, após uma longa descrição física e psicológica - "As palavras saíam-Ihe lentas e contadas, como a fazer sentir toda a munificência do autor"131 - , aponta seu pior defeito:

"Tais eram os defeitos aparentes de Jorge. Outros havia, e desses, o maior era um pecado mortal, o sétimo. $O$ nome que the deixara o pai, a influência da tia podiam servir-lhe nas mãos para fazer carreira em alguma cousa pública; ele, porém, preferia vegetar à toa, vivendo do pecúlio que dos pais herdara e das esperanças que tinha na afeição da baronesa. Não se lhe conhecia outra ocupação."

A alusão ao pecado capital correspondente à soberba parece ser contraposta nas palavras seguintes. Possuidor das vantagens do nascimento,

${ }^{131}$ A mão e a luva, p. 223. 
ele não se esforça para ir além da posição garantida pela família. ${ }^{132}$ Tudo, nessa caracterização, contrapõe-se frontalmente à construção da protagonista, vista no capítulo anterior. Os "defeitos" e "pecados" do rapaz ressaltam as qualidades e virtudes da moça inteligente e disciplinada; o nome do pai faz lembrar a insignificância da filiação obscura de Guiomar; o estado vegetativo contrasta com o esforço extremo da menina; e, por fim, a afeição da baronesa com o sobrinho decorria do parentesco, enquanto o sentimento da madrinha para com a heroína foi conquistado e cultivado progressivamente. Este último dado justificará, ao final, o prevalecimento da vontade dela em detrimento do desejo inicial da tia e do rapaz.

Em relação aos dois pretendentes surgidos até então, Guiomar adota a posição de neutralidade. Firme no propósito de se manter na direção correta, ela age sempre com cuidado:

\begin{abstract}
"Guiomar, no meio das afeições que a cercavam, sabia manterse superior às esperanças de uns e às suspeitas de outros. Igualmente cortês, mas igualmente impassível para todos, movia os olhos com a serenidade da isenção, não namorados, nem sequer namoradores. Ela teria, se quisesse, a arte de Armida; saberia refrear ou aguilhoar os corações, conforme eles fossem pacientes ou tíbios; faltava-Ihe porém o gosto, ou melhor, sobrava-Ihe o sentimento do que ela achava que era sua dignidade pessoal." 133
\end{abstract}

\footnotetext{
${ }^{132}$ Notemos a vinculação frequente, na obra romanesca de Machado, entre a carreira política e/ou pública ao verniz social. Nas três obras analisadas em nosso estudo, tal tópico aparece como questão importante no relevo social das famílias. Sendo ou não realizado, o projeto político é sempre um tópico a ser debatido.

${ }^{133}$ A mão e a luva, p. 224.
} 
Novamente, o narrador chama a atenção para a perseverança de Guiomar em seu projeto e faz uma analogia interessante entre ela e Armida, a personagem de Jerusalém Libertada (1581), de Torquato Tasso. No poema de caráter épico do século XVI, que narra a disputa de Jerusalém entre árabes e cristãos, Armida, dotada de grande beleza e artimanhas, é enviada à guerra pelo rei mouro para seduzir e afastar os guerreiros do campo de batalha. Além de desestruturar a formação bélica, ela consegue também aliciar companheiros para lutarem com ela, vencendo, assim, essa primeira disputa. ${ }^{134}$ Ora, a referência ao texto italiano, baseado na llíada de Homero, desloca ironicamente o enredo brasileiro, apontando o caráter diminuto daquele círculo quase familiar, no qual uma matriarca, uma governanta, uma afilhada agregada e três pretendentes buscam alcançar o resultado que melhor Ihes agrade. Do mesmo modo, o esforço despendido por Guiomar para manter o controle da situação é mínimo nesse momento, podendo assemelhar-se a um campo de batalha somente em clave paródica. Contudo, a menção à sua superioridade e à dignidade pessoal posiciona-a acima de todas as figuras. Note-se, mais uma vez, quão sinuoso é o narrador. Indica a possibilidade de Guiomar ser como Armida, mas, em seguida, toma o caminho oposto. Desse modo, sua vitória futura já está indiciada.

Retomando as investidas insistentes de Estêvão, temos uma última seção das sequências que diferenciam Guiomar das outras personagens. Após mostrar a decisão atrapalhada de um "coração frouxo" e "pusilânime" de declarar-se uma última vez à moça "firme" e "segura", que ouvia aquilo com

\footnotetext{
134 TASSO, Torquato. (trad. COELHO, José Ramos/ LUCCHESI, Marco) Jerusalém libertada. Rio de Janeiro: Topbooks, 1998.
} 
"impaciência e ansiedade de acabar", o texto apresenta a resolução do impasse com uma recomendação significativa de Guiomar:

"- Dou-lhe um conselho, disse Guiomar depois de alguns segundos de pausa, seja homem, vença-se a si próprio; seu grande defeito é ter ficado com a alma de criança." ${ }^{135}$

As palavras acima, mais que caracterizarem o moço, revelam os anseios dela mesma, que se supera continuamente a fim de lograr sucesso. Interessante notar que tal diálogo ecoa um conselho anterior dado a ela por Mrs Oswald:

“ [...] Um conselho último - último se me não consentir mais falar-lhe nisto; - eu creio que a senhora sonha talvez demais. Sonharás uns amores de romance, quase impossíveis? DigoIhe que faz mal, que é melhor, muito melhor contentar-se com a realidade; se ela não é brilhante como os sonhos, tem pelo menos a vantagem de existir." 136

A essa orientação da inglesa, Guiomar responde a si em pensamento: "_ Sonhos, não, realidade pura". ${ }^{137}$ Assim como os termos de Guiomar na conversa com Estêvão fazem transparecer seu sentimento íntimo, aqueles utilizados pela governanta também estão de acordo com o dela. A inglesa, na condição de agregada, não cultiva idealismos e sugere que a moça tenha a mesma postura, pois, mesmo em posição mais privilegiada, não deixa de depender de uma terceira pessoa. Todavia, o que escapa do entendimento da senhora e do jovem enamorado é a altivez de Guiomar. Nesse sentido, a constituição da personagem parece filiar-se a figuras de caráter superior da

\footnotetext{
${ }^{135}$ A mão e a luva, p. 227.

${ }^{136}$ Idem, p. 222.

${ }^{137}$ Idem, p. 223.
} 
literatura do século XVIII, como Fígaro ${ }^{138}$, e a heroínas românticas do século XIX (como Lucíola e a Dama das Camélias, dos romances homônimos, e Aurélia Camargo, de Senhora). Nelas há certa reserva moral que as faz, mesmo em situação adversa, se fazer respeitar e vencer o meio, valorizandose a condição pessoal e não a origem privilegiada.

Assim, acompanhamos o narrador num movimento contínuo que ora aponta para a conduta puramente estratégica da personagem, ora para a revelação da existência de sentimentos corretos e verdadeiros para com aqueles que a cercam. Ela responde secamente a Mrs Oswald, mas depois pega carinhosamente em suas mãos; a impaciência ao ouvir as lamentações de Estêvão logo dão lugar à "comiseração e à piedade"139; o rosto "tão frio e tão nu" ${ }^{140}$ não implica "um coração tão mau, que Ihe não doessem as mágoas de um homem que acertara ou desacertara de a amar"141.

De todas as relações travadas, sem dúvida, a mais delicada e complexa se dá com a baronesa, pois esta ocupa a posição mais alta da hierarquia social. Empenhada no direcionamento de seu destino, Guiomar não descuida da manutenção dos cuidados com a madrinha. Vejamos:

\footnotetext{
${ }^{138}$ A discussão do merecimento social decorrente apenas do nascimento aparece no monólogo de Fígaro do Quinto Ato: "Só porque é nobre o senhor fica pensando que também é gênio!...Nobreza, dinheiro, posição, palácios dão muito convencimento! O que é que o senhor fez para merecer tudo isso? Deu-se apenas ao trabalho de nascer e nada mais: fora isso, é um homem perfeitamente medíocre! Enquanto eu, raios me partam, perdido no meio da multidão obscura, tenho tido de usar mais ciência só para não morrer do que foram aplicados nos últimos cem anos para governar as Espanhas; e o senhor quer medir forças comigo!", BEAUMARCHAIS, Pierre A. C. de. As Bodas de Fígaro. Trad. Barbara Heliodora. São Paulo: Edusp, 2001, p. 148.

${ }^{139}$ A mão e a luva, p. 227.

140 Idem, p.228.

${ }^{141}$ Idem.
} 
"Ela vivia do presente e do futuro e, - tamanho era o seu futuro, quero dizer as ambições que Iho enchiam, - tamanho, que bastava a ocupar-Ihe o pensamento, ainda que o presente nada mais lhe dera. Do passado nada queria saber; provavelmente havia-o esquecido.

A madrugada achou-a dormindo; mas os primeiros raios de sol vieram acordá-la, na forma de costume, para o matinal passeio com a madrinha. Guiomar sacrificava tudo à dedicação filial de que já dera tantas provas. "142

O procedimento narrativo que conjuga racionalidade e afeição genuína percorre toda a narrativa, de modo que passagens como essa se repetem ao longo do texto. O narrador aponta para um perfil ambicioso, chegando até uma quase acusação da indiferença de Guiomar acerca do passado, ou seja, das origens, família humilde, etc., como se sua verdadeira existência tivesse passado a fazer sentido somente após a transferência para a nova casa. Logo a seguir, observamos o que parece ser expressão de real sentimento por aquela que a acolhera, pois o verbo "sacrificar" somado às "tantas provas" faz com que a informação pareça confiável. Tal dado se confirma na resposta da baronesa dada ao sobrinho ao ser questionada sobre a situação da moça na família:

"_ [...] Henriqueta não teve melhor coração nem mais amor aos seus. Além disso, a natureza deu-lhe espírito superior, de maneira que a fortuna não fez mais do que emendar o equívoco do nascimento." 143

\footnotetext{
${ }^{142}$ A mão e a luva, p. 229.

${ }^{143}$ Idem.
} 
A madrinha não somente confirma a percepção da veracidade do laço que as une, mas eleva Guiomar acima da própria filha, fazendo com que o sentimento e o "espírito superior" criem uma nova relação com a afilhada, tornando-a indiscutivelmente maternal. A confiança na consolidação do vínculo será fundamental para que a protagonista se sinta segura na recusa da aliança com Jorge:

"Até que ponto chegaria seu adorador se ela o desatendesse logo; e, dado o amor que a baronesa tinha ao sobrinho, até que ponto a recusa iria magoá-la? Guiomar varreu do espírito os receios que nasciam de tais interrogações; mas sentiu-os primeiro, pesou-os antes de os arredar de si, o que revelará ao leitor em que proporção estavam combinados o sentimento e a razão, as tendências da alma e os cálculos da vida." 144

Por meio do discurso indireto livre, são primeiramente expostas as preocupações justificadas de Guiomar acerca do caráter delicado da questão, pois a reação negativa da madrinha seria o principal obstáculo à sua decisão. Com esse procedimento, o narrador faz com que o leitor se solidarize com seus questionamentos para, na sequência, analisar o modo de proceder da personagem. Tal forma de atuar, na qual se sucedem pensar, avaliar e só então agir, se faz presente na resolução das principais situações do texto, sobretudo nas que envolvem o possível casamento.

Cortejada até o momento por dois homens, Estêvão e Jorge, Guiomar considera calmamente suas possibilidades e as implicações de cada uma delas. Não pode casar-se com o primeiro, porque, apesar do sentimento

\footnotetext{
${ }^{144}$ A mão e a luva, p. 233.
} 
intenso, ela lastima que "tal coração não fora casado a outro espírito" ${ }^{145}$; nem com o segundo, cuja paixão parece forjada e o caráter acomodado a repele.

Tendo apresentado os dois primeiros possíveis noivos, bem como os fatos favoráveis e adversos relativos a eles, somos levados ao interior do escritório de Luís Alves. Essa introdução da personagem, antes mesmo de sinalizar qualquer contato do advogado com Guiomar, se dá logo em seguida às ponderações feitas nos parágrafos anteriores e produz evidente efeito de comparação:

\begin{abstract}
"A preocupação de Luís Alves por aqueles dias era a candidatura eleitoral; a boa nova devia chegar-lhe na primeira mala do Norte. Ora, em boa razão, um homem que está prestes a ser inscrito nas tábuas do parlamento, não pode cogitar muito dos amores de um rapaz, ainda que o rapaz seja amigo e os amores verdadeiros" 146
\end{abstract}

O trecho acima revela a maneira extremamente eficaz com a qual o narrador faz a apresentação da figura cumprir várias funções no espaço sucinto de duas frases. Ele descreve o perfil de Luís Alves, contrapõe-no aos de Estêvão e Jorge e alinha-o com o de Guiomar. A primeira informação da preocupação com a candidatura mostra a diferença entre o empenho na direção de engendrar uma carreira pública, que, por sinal, já está em andamento, demonstrando mérito pessoal - o texto não menciona qualquer privilégio familiar - e a inércia de Jorge para traçar percurso de algum relevo social, mesmo possuindo as vantagens do nascimento e os favores da tia. Por outro lado, na segunda sentença, a oposição com Estêvão é evidente. A prevalência da "razão" sobre o amor e a amizade denota a praticidade com que

\footnotetext{
${ }^{145}$ A mão e a luva, p. 233.

${ }^{146}$ Idem, p. 241.
} 
lida com os percalços da vida, indicando que tem postura de "homem" e não de "criança", defeito assinalado por Guiomar no conselho que dera a Estêvão. Também temos aqui uma consonância com tudo o que já foi dito a respeito da protagonista. O equilíbrio dos sentimentos, a ponderação dos atos e as escolhas refletidas são predicados atribuídos a ambos. Há, em toda a narrativa, passagens referentes a um e outro formando imagens como que especulares da dupla. Tomemos dois exemplos:

\begin{abstract}
"Guiomar refletiu ainda muito e muito, e não refletiu só, devaneou também, soltando o pano todo a essa veleira escuna da imaginação, em que todos navegamos alguma vez na vida, quando nos cansa a terra firme e dura, e chama-nos o mar vasto e sem praias. A imaginação dela porém não era doentia, nem romântica, sem piegas, nem Ihe dava para ir colher flores em regiões selváticas ou adormecer à beira de lagos azuis. Nada disso era nem fazia; e por mais longe que velejasse levaria entranhadas na alma as lembranças da terra." ${ }^{147}$
\end{abstract}

"As últimas palavras que disse ao colega foram duas ou três pilhérias de rapaz; mas apenas ficou só tornou-se sério, e inclinando o corpo para a frente, com os braços na secretária, e a raspar as unhas com um canivete, ali esteve largo tempo, como a refletir, longe de Estêvão, que aliás já não ia perto, e ainda mais longe dos autos que tinha diante de si. Mas em que pensava ele, se não era em Estêvão, nem nos autos, nem também, por agora, nas suas esperanças eleitorais? Paciência, leitor, sabê-los-ás daqui a nada. Contenta-te com a notícia de que, ao cabo de vinte minutos daquela abstração, Luís Alves volveu a si, proferindo em voz alta esta simples palavra:

_ Não há dúvida; é uma ambiciosa.

E descativado daquela preocupação, enterrou-se de todo na leitura dos autos." 148

\footnotetext{
${ }^{147}$ A mão e a luva, pp. 233, 234.

148 Idem, pp. 241, 242.
} 
No primeiro extrato, deparamo-nos com uma série de vocábulos antagônicos correspondentes à tônica do romance, corroborando a combinação mencionada anteriormente de "sentimento e razão", "tendências da alma e cálculos da vida". Interessante notarmos também que o tom do texto se eleva por uma espécie de suspensão fantasiosa ao lançar mão de expressões poéticas do tipo "devaneios" e metafóricas como "veleira escuna da imaginação" e "navegamos", sem, todavia, deixar de relembrar a ancoragem na "terra firme e dura" da realidade. O mesmo procedimento pode ser verificado na frase seguinte. Todos os termos referentes ao universo das ilusões: "doentia", "romântica", "piegas" e "colher flores", vêm precedidos pelos advérbios de negação "não" e "nem" e pela preposição "sem", indicando forte insistência no distanciamento da personagem em relação a esses tipos de sentimentos.

A descrição da introspecção de Luís Alves parece ser ainda mais ancorada no prosaísmo que a de Guiomar. Se, por alguns instantes, abandona o trabalho do escritório para pensar sobre a afilhada da baronesa, ele o faz sem qualquer demonstração de ansiedade. A banalidade do espaço e da ação fica evidente quando o narrador o expõe pensando "com os braços na secretária, raspando as unhas com o canivete". A constatação sumária de que Guiomar "é uma ambiciosa" desperta seu interesse, mas, ao contrário de Estêvão, que se viu transtornado a ponto de pensar em suicídio, não interfere em absoluto nos seus afazeres, pois volta à leitura de seus autos como se nenhuma grande emoção decorresse de tal reflexão. Temos, portanto, uma encarnação do pragmatismo nessa personagem que o texto demonstra estar em possível acordo com os anseios da heroína. 
As (im)possibilidades de casamento em Helena

Assim como em $A$ mão e a luva, serão relatadas em Helena as habilidades da moça em lidar com os membros da casa e resolver as tratativas de casamento. Muitos procedimentos narrativos encontrados naquela obra serão observados nesta. A contraposição e a similaridade entre as figuras evidenciarão o motivo da paixão que surgirá entre Helena e Estácio. Para tanto, após ter mencionado muitas das virtudes de Helena, o narrador se dedica a traçar o perfil de Eugênia através de um diálogo entre ela e o namorado. Depois de chamar a atenção para a decepção desproporcional da menina acerca do comentário negativo de uma amiga sobre um mero chapéu, temos a seguinte fala do rapaz:

“_Eugênia, disse Estácio, quer saber a verdadeira razão do mau sucesso de suas afeições? É deixar-se levar mais pelas aparências que pela realidade; é porque dá menos apreço às qualidades sólidas do coração do que às frívolas exterioridades da vida. Suas amizades são das que duram a roda de uma valsa, ou quando muito, a moda de um chapéu; podem satisfazer o capricho de um dia, mas são estéreis para as necessidades do coração." ${ }^{149}$

Vemos novamente nesse texto aquela mesma forma de conselho, vista anteriormente nas enunciações de Mrs Oswald a Guiomar e desta a Estêvão. Com função de expor as diferenças entre Estácio e Eugênia, reforçadas em

${ }^{149}$ Helena, p. 290. 
seguida pelo narrador: "as divergências morais daquelas duas criaturas" ${ }^{150}$, tais colocações também contrastam com a constituição de Helena, ressaltando ainda mais a harmonia dos irmãos - ela se interessa igualmente por literatura (toma emprestado o volume de Manon Lescaut da biblioteca dele) e prefere discutir ideias e sentimentos às questões "frívolas" preferidas pela filha de Camargo.

Menos estável que Guiomar, Helena, por vezes, vacila na firmeza da manutenção da posição que ocupa na casa, deixando escapar as apreensões de sua condição, sempre depois de alguma indagação de Estácio ao perceber tais inquietudes, como no exemplo abaixo:

"Estácio entrou pensativo; Helena mudou totalmente de ar e maneiras. Alguns segundos antes era sincera a melancolia que the ensombrava o rosto. Agora regressara à jovialidade de costume. Dissera-se que a alma da moça era uma espécie de comediante que recebera da natureza ou da fortuna, ou talvez de ambas, um papel que a obrigava a mudar continuamente de vestuário." 151

As dúvidas do irmão surgem justamente da percepção da inconstância no comportamento de Helena. Variando entre sentimentos de infortúnio e felicidade, ela mantém-se mais resoluta sob os olhos de D. Úrsula. A grande capacidade de modificar o semblante em "segundos" ajuda-a a continuar encobrindo sua identidade verdadeira, ação reforçada pelo narrador ao referirse a ela como uma "comediante" desempenhando um "papel". Desse modo, podemos inferir também sua força de vontade para continuar desfrutando de

\footnotetext{
${ }^{150}$ Helena, p. 291.

151 Idem, p. 299.
} 
privilégios que estão garantidos pelo testamento do conselheiro, cuja legitimidade infundada continua desconhecida dos outros membros da família. As desconfianças a esse respeito são ainda mais contundentes por parte da tia. Ao ser questionada pelo sobrinho sobre o que acha da declaração da menina ao dizer, num instante de instabilidade, que é "uma pobre alma lançada num turbilhão" ${ }^{152}$, a senhora responde:

" [...] a frase de Helena é achada em alguns dos muitos livros que ela lê. Helena não é tola; quer prender-nos por todos os lados, até pela compaixão. Não te nego que começo a gostar dela; é dedicada, afetuosa, diligente; tem maneiras finas e algumas prendas da sociedade." 153

Do grande empenho de Helena, sustentado por "uma razão forte e clara"154 aliada a "outras qualidades feminis"155, vai consolidando-se sua posição privilegiada no seio daquela família. Através de uma voz narrativa que ora aponta para o caráter objetivo da personagem, ora reforça suas afeições verdadeiras, o enredo varia entre um tom sisudo e, outro, às vezes, jocoso. Um exemplo desse último matiz ocorre numa das cenas mais prosaicas do romance, chegando a beirar a pilhéria. No meio dos diversos assuntos a serem tratados - o casamento de Estácio com Eugênia, sua candidatura a deputado e a apreensão de Helena acerca de sua identidade - deparamo-nos com a seguinte passagem:

\footnotetext{
${ }^{152}$ Helena, p. 299.

153 Idem, p. 390.

154 Idem, p. 303.

155 Idem.
} 
"Durante dous dias não saiu ele [Estácio] de casa. Tendo recebido alguns livros novos, gastou parte do tempo em os folhear, ler alguma página, colocá-los nas estantes, alterando a ordem e a disposição dos anteriores, com a prolixidade e o amor do bibliófilo. Helena ajudava-o nesse trabalho, - um pouco parecido com o de Penélope, - porque a ordem estabelecida ao meio-dia era às vezes alterada às duas horas, e restaurada na seguinte manhã. Estácio, entretanto, não ficava todo entregue aos livros; admirava a solicitude da irmã, a ordem e o cuidado com que ela o auxiliava. Helena parecia não andar; o vulto resvalava silenciosamente, de um lado para outro, obedecendo às indicações do irmão, ou pondo em experiência uma ideia sua. Estácio parava às vezes fatigado; ela continuava imperturbavelmente o serviço." ${ }^{156}$

Esse trecho suspende as ações principais da história para mostrar, de maneira irônica, a relação do casal. A analogia entre Helena e Penélope ressalta o caráter diminuto e doméstico da intriga brasileira ao compará-la às guerras monumentais da Odisséia, algo já indiciado pelo nome da heroína brasileira. O estratagema da esposa de Ulisses para ganhar tempo e não se casar remete à postergação da resolução de questões essenciais da narrativa, pois nesse intervalo nem Estácio nem Helena precisam tomar decisão alguma. O estilo jocoso continua com o apontamento do espírito pacato do rapaz, cansado apenas por ter organizado sua biblioteca, atividade banal se comparada às batalhas ferozes enfrentadas por Ulisses. Já a postura infatigável de Helena condiz perfeitamente com seu perfil de determinação para alcançar o que almeja. A grande harmonia entre os dois, sobretudo ao indicar a obediência de Helena, indica mais uma relação conjugal que fraternal, atenuando um pouco a comicidade de tais alusões, pois a conjuntura impede que a possibilidade amorosa se realize.

\footnotetext{
${ }^{156}$ Helena, p. 305.
} 
A relação com Penélope insiste, também, no aspecto do engano, próprio das mulheres vistas, muitas vezes no romantismo, como uma mistura de anjo e demônio. Não podemos nos esquecer de que isto é uma das bases em que se assentam certas ambiguidades das figuras machadianas. Também, a disseminação de elementos da tradição clássica indicadores do enigma da mulher reforça a astúcia de Helena, sobretudo se pensarmos na relevância de tal característica, fundamental não somente para o êxito de Penélope, mas também na vitória da guerra de Tróia por Ulisses.

Contudo, percebemos que o empenho primordial de Helena vai à direção de estabelecer-se na família e não de concretizar a paixão pelo suposto irmão. Para isso, continua firmemente a manter seu segredo frente às indagações suspeitosas de Estácio - "a inocência não teria mais puro rosto; a hipocrisia não encontraria mais impassível máscara" ${ }^{157}$-, conduzindo-o inclusive a acertar definitivamente o casamento com a filha de Camargo, servindo-se da forma do "conselho", mesmo procedimento visto em $A$ mão e a luva:

" Permite-me um conselho? Perguntou ela.

E como Estácio respondesse com um gesto de assentimento:

_ Vá ter com Eugênia, solicite licença para ir pedi-la a seu pai, e conclua isso quanto antes." ${ }^{158}$

Assim como no romance anterior, o conselho tem função de atender as expectativas de quem enuncia. Com o intuito de resolver a situação

\footnotetext{
${ }^{157}$ Helena, p. 306.

158 Idem, p. 307.
} 
do matrimônio de Estácio e, consequentemente, livrar-se de seu próprio problema, Helena faz mais que sugerir, pois os verbos no imperativo enfatizam sua real intenção, além do "conclua isso o quanto antes" revelar o caráter urgente da solicitação. Para justificar o tom de advertência, ela finaliza com uma definição bastante prática do que viria a ser o casamento:

“_ [...] O casamento não é uma solução, penso eu; é um ponto de partida. O marido fará a mulher. Convenho que Eugênia não tem todas as qualidades que você desejaria; mas, não se pode exigir tudo: alguma cousa é preciso sacrificar, e do sacrifício recíproco é que nasce a felicidade doméstica.“"159

Ora, a declaração da personagem faz transparecer uma visão socialmente aceita frente à natureza do matrimônio, pois ela mesma está disposta a assumir uma aliança conveniente que se sobreponha ao requisito exclusivo do afeto, de modo que prefere sacrificar o sentimento verdadeiro para obter posição adequada naquele círculo. Mais à frente, o narrador confirma tal suposição com o acerto do noivado entre Estácio e Eugênia: "Helena parecia colher naquele casamento a sua própria felicidade" ${ }^{160} \mathrm{~A}$ partir daí, passa a tratar de seu próprio destino, sinalizando para a união com Mendonça. Demonstra serenidade na eleição apoiada não na emoção, mas na decisão objetiva declarando que "o amor não é mais que um instrumento de escolha". ${ }^{161}$

\footnotetext{
${ }^{159}$ Helena, p. 307.

${ }^{160}$ Idem, p. 329.

${ }^{161}$ Idem, p. 337.
} 
O desenvolvimento da personagem na busca do espaço na família é trabalhado em dois tipos de conexão: com a figura masculina e com a matriarca. Nesse sentido, há uma semelhança significativa desta trama com a vista em $A$ mão e a luva. Em ambos os casos, uma mulher mais velha tem importância doméstica inegável, dado que centraliza e intensifica a abordagem da complexa relação maternal entre a agregada e a dona da casa. Guiomar pode provar sua afeição e lealdade durante o período de luto da madrinha; aqui, em situação similar, temos a grave doença de D. Úrsula cumprindo a mesma função, ou seja, fazendo com que a moça tenha a oportunidade de ratificar seus sentimentos e comprometimentos para com quem a acolheu:

\begin{abstract}
"Helena era naquela ocasião a natural enfermeira. Pela primeira vez patenteou-se em todo o esplendor a dedicação filial da moça. [...] Os remédios e o pouco alimento que esta [D. Úrsula] podia receber, não lhe eram dados por outras mãos. Helena velava à cabeceira, durante o sono leve e interrompido da doente, achando em suas próprias forças a resistência que a natureza confiou especialmente às mães. [...] Havia no coração de D. Úrsula uma fonte de ternura, que Helena devia tocar, para jorrar livre e impetuosamente. A dedicação, em tal crise, foi a vara daquele Horeb. [...] A experiência do caráter da moça dera esse resultado inevitável. [...] Não o ocultou a irmã do conselheiro; já não tinha acanhamento nem reserva, as palavras subiam do coração à boca sem atenuação nem cálculo; fez-se carinhosa e mãe." 162
\end{abstract}

A exacerbação da emoção, verificada nos termos referentes aos sentimentos de ambas, permeia todo o trecho, confirmando a solidificação de afeto recíproco. Helena, por meio de esforço extremoso, desempenha papel de mãe e filha, no qual a moça adulta começa a preparar-se para assumir as

${ }^{162}$ Helena, p. 308. 
responsabilidades do lar, tomando o lugar, até então, ocupado pela figura materna, assim como o fez Guiomar. A intensidade emotiva se revela ainda maior na referência do narrador à passagem bíblica, comparando a atitude de Helena à de Moisés quando este faz jorrar água da rocha para aliviar a sede dos hebreus no deserto. ${ }^{163} \mathrm{~A}$ alusão ao texto sagrado indica a transformação da relação entre as duas figuras, de maneira que ratifica a adoção da menina por parte da nova mãe. Tal fórmula torna Guiomar e Helena heroínas mais intrigantes, pois a representação do arrivismo aparece atenuada pela existência genuína de amores passionais e maternos. Temos, portanto, nas duas obras, protagonistas constituídas por meio da conjunção de inteligência e sentimento, bem como de ambição social e apreço verdadeiro.

União e divisão: os espaços de A mão e a luva e Helena

Os ambientes pelos quais circulam Guiomar e Helena são muito restritos e assim se resumem: casa da baronesa e chácara em $A$ mão e a luva e propriedade do conselheiro e cabana do verdadeiro pai em Helena. Essa limitação espacial se deve ao fato de Machado optar por construir narrativas essencialmente domésticas, focalizadas em tensões quase sempre íntimas, embora largamente lastreadas em perspectiva social abrangente: patriarcalismo e pouca possibilidade de ascensão (sobretudo para a mulher). Por isso, o campo de atuação das personagens é bastante resumido, de forma

${ }^{163}$ A passagem bíblica é relatada no Êxodo 17:1-7. 
que a astúcia cumpre papel fundamental para que resolvam seus dramas dentro dos limites estabelecidos.

Já na cena de abertura de $A$ mão e a luva, tomamos conhecimento da contiguidade da casa da madrinha com a de Luís Alves:

"O jardim ficava nos fundos da casa; era separado da casa vizinha por uma cerca. Relanceando os olhos pela chácara, viu Estêvão que era plantada com esmero e arte, assaz vasta, recortada por muitas ruas curvas e duas grandes ruas retas. Uma destas começava das escadas de pedra da casa e ia até o fim da chácara; a outra ia da cerca de Luís Alves até a extremidade oposta, cortando a primeira no centro."164

A proximidade entre as duas residências fica evidente com a disposição de fronteiras flexíveis representadas por uma cerca baixa e ilustradas por descrições detalhadas das ruas e dos jardins interiores. A possibilidade de observação mútua entre os moradores das propriedades antecipa o inevitável contato posterior a ser estabelecido entre elas, tal como, mais tarde, em Dom Casmurro.

Estabelecida no domicílio elegante da madrinha, Guiomar terá apenas o trabalho de estender seu espaço aos domínios de Luís Alves, o qual concluímos não estar em nível social e econômico inteiramente díspar daqueles da baronesa. Não por caso, o casamento será celebrado na chácara, de modo que a cerca será simbolicamente abolida com a união do casal, transformando as duas residências em uma única propriedade a simbolizar a perfeita conjunção do par.

${ }^{164}$ A mão e a luva, p. 207. 
No caso de Helena, notamos, desde o início, uma divisão clara e rígida entre o casarão do conselheiro e a pequena cabana de Salvador, indicada pela cavalgada matutina entre uma e outra e ilustrada pelo desenho feito por Helena na ocasião do aniversário de Estácio: "[...] era uma parte de Andaraí, a mesma por onde eles costumavam passear [...]; ao longe, e acima via-se a velha casa da bandeira azul [...]". ${ }^{165}$

A opção pela manutenção sistemática de duas existências - a protagonista se faz diariamente presente em ambas - revela a virtual impossibilidade de uni-las. Além disso, a discrepância entre a residência rica e a humilde acentuada pelo "calafrio"166 sentido por Estácio na visita a Salvador, perante a miséria dos móveis e da refeição, aponta para o desfecho irreconciliável de situações tão contrastantes.

Helena hesita, no decorrer de todo o enredo, entre o espaço da falsa posição social - a casa do conselheiro - e o da realidade de sua situação - o casebre do pai verdadeiro. $O$ pêndulo se mantém em movimento até a descoberta de seu segredo. Notemos que a resolução do drama não decorre da ação da personagem. Guiomar conduz as ações de seu destino, de modo até ousado, com o estratagema do bilhete ordenando Luís Alves que a peça em casamento; já Helena deixa a emergência dos fatos reger sua trajetória, não atuando como articuladora na situação final e decisiva. Assim, a união espacial de $A$ mão e a luva é representada pelo casamento e a incompatibilidade dos meios, em Helena, culmina na morte da heroína. A casa

\footnotetext{
${ }^{165}$ Helena, p. 316.

${ }^{166}$ Idem, p. 354.
} 
do conselheiro funciona, para Helena, como um espaço de usurpação, em consonância com o dado arrivista.

Porém, a personagem ambígua, que ela representa, será punida pelo destino, morrendo no mesmo lugar, o qual se transforma, em virtude da trama romântica, em local de expiação. Tal desfecho Ihe confere, ao fim da obra, uma "aura" que o leitor aceita, pois o pesar da perda contamina integralmente o texto.

Nesse sentido, o caso de Guiomar é díspar, porque não há fraude, mas incorporação. Ela encarna a figura da filha morta e a baronesa a vê como possibilidade mesma de tal substituição. Desse modo, o espaço passa ser o de adequação, para o qual a personagem está - segundo as reiterações do narrador - preparada.

Sofia e a casa do Flamengo

Vimos que a representação do arrivismo, nos romances anteriores, passa por duas vias paralelas: a conquista da matriarca pela protagonista e a resolução dos obstáculos referentes ao casamento. Tal complexidade aponta para algo além do arrivismo. Indica, mais do que nunca, a ambiguidade da mulher nesse tipo de sociedade, uma vez que não se consegue, de modo claro e indiscutível, distinguir-se onde termina o interesse e onde começa o sentimento mais caritativo. Em Quincas Borba, por se tratar da 
ascensão de um casal, temos uma situação distinta, apesar de o foco principal incidir também sobre a figura feminina.

É possível dizer que o tom narrativo predominante no tratamento de Sofia é o da sedução manifestada de formas diversas. Veremos, no decorrer da análise, duas tendências alternantes entre uma atração interesseira e outra verdadeira. Da mesma forma que a necessidade de identificação maternal suaviza o caráter ambicioso de Guiomar e Helena, o desejo de viver uma aventura amorosa dispersa, algumas poucas vezes, o foco principal da personagem. Vejamos com esses aspectos se constituem no texto.

Além de Rubião, aparece mais um cortejador para a lista de Sofia: Carlos Maria. Este, sem o menor constrangimento em galantear uma dama casada, lança a ela as seguintes palavras:

"_ O mar batia com força, é verdade, mas meu coração não batia menos rijamente; - com esta diferença que o mar é estúpido, bate sem bater por quê, e o meu coração sabe que batia pela senhora." ${ }^{167}$,

referidas logo após o narrador comentar as impressões de Sofia ao relembrar o ocorrido:

"[...] ela sorriu, sem tédio, sem dor de cabeça, ao contrário daquela noite de Santa Teresa, em que relatou ao marido os atrevimentos de Rubião. É que os morros serão doentios, e as praias saudáveis." 168

\footnotetext{
${ }^{167}$ Quincas Borba, p. 704.

168 Idem, p. 707.
} 
No decorrer do enredo, Sofia reclama apenas uma única vez ao marido - no momento da primeira declaração de Rubião ainda na casa de Santa Teresa - as inúmeras investidas por parte deste e de Carlos Maria. Tendo feito o companheiro tomar conhecimento de tais atrevimentos, acertouse entre os dois a conveniência de não os repelir e de, até mesmo, relevá-los por conta dos negócios travados com o amigo mineiro. No caso das passagens acima, as circunstâncias são outras. Não há qualquer reprovação por parte dela no ato de tal proclamação.

Outro dado fundamental a ser observado é a associação do espírito de Sofia à localização geográfica da residência. Pode-se dizer que há, na narrativa, três momentos correspondentes à posição social do casal, representados simbolicamente pelos endereços: a casa de Santa Teresa, a do Flamengo e o palacete de Botafogo. Nesse período intermediário, observamos um movimento duplo na evolução da personagem: de preocupação com a elevação social e de deixar-se embalar, às vezes, pelas ilusões passionais. 0 espaço físico é indissociável do ânimo da figura, de maneira que a mudança para um bairro melhor influi diretamente em seu estado psicológico.

A grande importância da alteração do espaço se dá também porque dela decorrem outras mudanças dos hábitos de Sofia. Essa transformação em etapas faz com que ela apreenda gradualmente os códigos de comportamento fundamentais para se fixar no novo meio. Há, em paralelo, um dado constante nesse processo: o contínuo aliciamento de Rubião por parte do casal. Essa estratégia só terá fim com a garantia do êxito da família. Sua trajetória, no romance, inicia-se partir da entrada no trem de Vassouras, já casada. Portanto, vamos vê-la sempre em ação de ascensão social. Por isso 
mesmo, ela será objeto de fascínio e logro da personagem principal, Rubião, cuja trajetória, pensamentos e decadência acompanhamos o tempo todo.

Vejamos como a sedução colabora com os planos de Sofia, que resolve organizar uma comissão aparentemente filantrópica para ajudar as vítimas de certa epidemia nas Alagoas, mas, certamente, a intenção passa longe do altruísmo, como assinala o narrador, no momento em que a moça explica a Rubião do que se tratava o grupo:

\begin{abstract}
"Rubião, de cabeça, subscreveu logo uma quantia grossa, para obrigar os que viessem depois. Era tudo verdade. Era também verdade que a comissão ia pôr em evidência a pessoa de Sofia, e dar-lhe um empurrão para cima. As senhoras escolhidas não eram da roda da nossa dama, e só uma a cumprimentava; mas, por intermédio de certa viúva, que brilhara entre 1840 e 1850, e conservava de seu tempo as saudades e o apuro, conseguira que todas entrassem naquela obra de caridade. Desde alguns dias não pensara em outra cousa. Às vezes, à noite, antes do chá, parecia dormir na cadeira de balanço; não dormia, fechava os olhos para considerar-se a si mesma, no meio das companheiras, pessoas de qualidade. Compreende-se que este fosse o assunto principal da conversação; mas, Sofia tornava de quando em quando ao presente amigo. Por que é que ele fazia fugidas tão longas, oito, dez, quinze dias e mais?" 169
\end{abstract}

Imersa em suas conquistas recentes, ela não descuida, contudo, da relação com Rubião. A pergunta acerca dos sumiços do amigo, colocada em discurso indireto, faz com que ela se misture aos devaneios da personagem, produzindo efeito de associação entre a presença-ausência dele e o processo de ascensão dela. Outrossim, a gradação dos números faz transparecer no questionamento um suave protesto, como se estivesse

${ }^{169}$ Quincas Borba, pp. 721, 722. 
reclamando ao namorado, de forma sedutora, a sua falta. Na recepção seguinte oferecida pelo casal para celebrar o aniversário de Sofia, ele era o único remanescente do círculo antigo:

\begin{abstract}
"Poucos eram os convivas; houve propósito em escolher e limitar. Não estava ali o Major Siqueira, nem a filha, nem as senhoras e os homens que Rubião conheceu naquele outro jantar em Santa Teresa. Da comissão das Alagoas viam-se algumas damas; via-se mais o diretor do banco, - outro personagem bancário, um comerciante inglês, um deputado, um desembargador, um conselheiro, alguns capitalistas, e pouco mais.

Posto que evidentemente gloriosa, Sofia esqueceu por um instante os outros, quando viu Rubião entrar na sala e caminhar para ela.[...] Sofia apertou-Ihe a mão com força e sussurrou um agradecimento. À mesa fê-lo sentar ao pé de si [...]. Rubião olhava superiormente para tudo. A qualidade dos convivas não the produziu impressão, nem o ar cerimonioso, nem o luxo da mesa; nada disso o deslumbrou." ${ }^{170}$
\end{abstract}

A cena acima é relevante, pois agrupa alguns dos principais aspectos da construção do texto. O desaparecimento das amizades anteriores e familiares seguido pela enumeração de figuras pertencentes aos universos financeiro e político ilustra o sucesso de Sofia, cujo empenho "trouxe novas relações à família". ${ }^{171}$ Portanto, o texto narrativo joga com a presença de Rubião e a ausência dos antigos amigos. Aqui, o jogo sutil do narrador insiste em apontar profissões e distinções sociais, em paralelo com a outra casa. Nem o professor é o mesmo, pois está dividido em duas figuras: o burguês provinciano enriquecido e o "imperador" de opereta.

\footnotetext{
${ }^{170}$ Quincas Borba, p. 740.

${ }^{171}$ Idem, p. 744.
} 
Mais adiante, temos a dúbia conexão de Sofia e Rubião, pendendo entre interesse e sedução. Ele Ihe havia enviado "magnífico brilhante" ${ }^{172}$, ocasionando grande impacto, pois "batia-lhe o coração"173 e o seguinte pensamento: "Aquele homem adora-me"174. Além disso, a atmosfera irônica fica evidente na descrição da altivez de Rubião, decorrente não do orgulho social adquirido, mas do avanço da demência. Não poderia haver elegância que o impressionasse, pois já ocorriam os acessos de delírio nos quais imaginava ser Napoleão III. A partir desse momento, a escalada dos Palha será proporcional à derrocada de Rubião, com a contínua ascensão daqueles e a crescente loucura deste.

A assimilação progressiva de Sofia ao novo patamar de vida ocorre quase sem percalços devido à sua grande habilidade. Carlos Maria, conhecido do casal desde os primeiros tempos, é a única personagem que percebe falha no domínio dos códigos sociais, pois "achava que as maneiras polidas da moça vinham da imitação adulta, após o casamento, ou pouco antes, que ainda assim não subiam muito do meio em que vivia". ${ }^{175}$

A introdução gradual da cultura francesa com a Revista dos Dous Mundos e o romance de Feuillet trazem um novo mundo de sensações, leituras e devaneios dos quais Carlos Maria, via sensualidade, faz parte. Para uma nova situação social, uma nova mulher e um parceiro diferente. Segundo Gilberto Pinheiro Passos:

\footnotetext{
172 Quincas Borba, p. 740.

173 Idem.

174 Idem.

175 Idem, p. 708.
} 
"a imersão [nessas] histórias [...] introduz a personagem num clima tal que os elementos oníricos serão consequência imediata, pois a "realidade" se vê toldada pela ficção e submetida à prova de sonho, no qual a imagem e o nome de Carlos Maria se recuperam: Estava deante da mesma parede de cerração daquele dia, mas no mar, à proa de uma lancha, deitada de bruços, escrevendo com o dedo na água um nome - Carlos Maria." ${ }^{176}$

Rico e bem-nascido, "frio e superior"177, "senhor de si e ainda mais dos outros"178, o rapaz parece combinar perfeitamente com os ânimos da esposa de Palha. No entanto, Rubião é quem sustenta tal estado de coisas. Apoiada nele, Sofia almeja outro homem.

A transição definitiva de uma classe a outra é, mais uma vez, comentada pelo Major Siqueira: "Quem nunca comeu azeite, quando come se lambuza"179. O fato de tais comentários serem proferidos pelo amigo dos primeiros tempos se deve ao fato de ele representar a percepção do antigo grupo a que o casal pertencia, daí o uso de uma frase proverbial em consonância com a voz média. Além disso, o militar e a filha são exemplos de certa imobilidade social um tanto rancorosa, de modo que, parados onde estão, assistem indignados à movimentação e ao comportamento inescrupuloso do casal, como exemplifica a passagem abaixo:

176 PASSOS, Gilberto Pinheiro Passos. O Napoleão de Botafogo: Presença Francesa em Quincas Borba de Machado de Assis. São Paulo: Annablume, 2002, pp. 34, 35.

\footnotetext{
${ }^{177}$ Quincas Borba, p. 664.

${ }^{178}$ Idem.

${ }^{179}$ Idem, p. 756.
} 
"Foi assim que nossa amiga, pouco a pouco, espanou a atmosfera. Cortou as relações antigas, familiares, algumas tão íntimas que dificilmente se poderiam dissolver; mas a arte de receber sem calor, ouvir sem interesse e despedir-se sem pesar, não era de suas menores prendas; e uma por uma, se foram indo as pobres criaturas modestas, sem maneiras nem vestidos, amizades de pequenas monta, de pagodes caseiros, de hábitos singelos e sem elevação." 180

A descrição do comportamento quase cruel de Sofia revela seu comprometimento, até maior que o do marido, na promoção da família. Diferentemente do salão de Madame Verdurin, cujos membros avançarão como um conjunto, a substituição dos antigos convivas por outros de maior relevo será fundamental para a obtenção de prestígio na sociedade criada por Machado. Nesse universo conservador, não há muito espaço para inovação, pois ele se baseia principalmente na mimetização da elite. Ao conquistar o sucesso financeiro, o casal procura cercar-se de quem os equipara, pois, somente assim, conquistará o desejado lustre social.

O narrador usa a preposição "sem" quatro vezes, enfatizando o descaso e o distanciamento progressivo de Sofia. Do mesmo modo, a expressão "nossa amiga" revela a grande ironia do texto, pois tal sentimento não compõe seu perfil, visto que a amizade, tanto no círculo antigo quanto no novo, é simulada de acordo com a conveniência. A personagem arrivista passa de uma situação social a outra, desfazendo-se de hábitos, moradias, vestimentas e pessoas. Daí não haver calor, afeição, pesar e ser realçada a inadequação dos "sem maneiras", "sem elevação".

${ }^{180}$ Quincas Borba, p. 761. 
Odette Swann e seu salão literário

Se, em Du côté de chez Swann, a análise paralela de Odette de Crécy e Madame Verdurin é profíqua, visto que estão situadas no mesmo espaço, o salão da Rua Montalivet, a partir de À l'ombre des jeunes filles en fleurs podemos separar as abordagens, pois o contato entre ambas praticamente deixa de existir, mesmo que uma mantenha sempre a outra como referência. Há um salto temporal do primeiro volume, quando Odette era ainda amante de Swann, para o segundo, no qual já casada e com uma filha adolescente, Gilberte, começa a estabelecer seu próprio salão a exemplo do que fazia Madame Verdurin.

Para tanto, além de ser amante e ter tido uma filha com Swann, Odette precisa casar-se com ele para obter algum reconhecimento por parte de uma sociedade tão regulamentada. M. de Norpois, um antigo embaixador, será a personagem através da qual saberemos os detalhes referentes a esse período, justamente por transitar em diversos meios e conhecer diferentes pontos de vista. Ele frequenta tanto a família do narrador e a casa de Swann quanto ambientes aristocráticos, pois é amante de Madame de Villeparisis, de origem Guermantes. Tendo acompanhado a trajetória do casal desde o início, ele relata a estratégia de Odette:

"Il y a eu, il est vrai, dans les années qui précédèrent le mariage d'assez vilaines manoeuvres de chantage de la part de 
la femme; elle privait Swann de sa fille chaque fois qu'il lui refusait quelque chose. Le pauvre Swann, aussi naïf qu'il est pourtant raffiné, croyait chaque fois que l'enlèvement de sa fille était une coïncidence et ne voulait pas voir la réalité." ${ }^{181}$

A utilização da criança como instrumento de chantagem, apesar de moralmente questionável, é a única arma de que dispõe Odette, pois os vários anos de relacionamento e a filha em comum não parecem, num primeiro momento, convencer Swann da necessidade do casamento. Notemos, todavia, a interessante sugestão de Norpois, segundo a qual Odette arma o ardil de maneira tão habilidosa a ponto de as ausências parecerem mais casuais que intencionais, o que faz Swann decidir-se pelo matrimônio para intensificar o contato com a menina, sem perceber sua submissão às ameaças. Com a oficialização da união, a antiga cocotte dá o primeiro passo em direção a uma nova existência.

As primeiras informações que temos a respeito das recepções do casal Swann vêm da família do narrador em conversas com alguns frequentadores e, mais adiante, do próprio Marcel, amigo da filha de Odette, quando passa a ser assíduo nas visitas àquele meio. As informações são passadas ao leitor por pessoas interpostas. Tal artifício insiste no caráter balzaquiano de um contínuo social, com vários pontos de vista.

Indagado pela mãe do protagonista, M. de Norpois faz a primeira descrição do ambiente:

"Mon Dieu... c'est une maison où il me semble que vont surtout... des messieurs.[...]

${ }^{181}$ À l'ombre des jeunes filles en fleurs, I, p. 458. 
Je dois dire, ajouta-t-il, pour être tout à fait juste qu'il y va cependant des femmes, mais appartenant plutôt..., comment dirais-je, au monde républicain qu'à la société de Swann. Qui sait? Ce sera peut-être un jour un salon politique ou littéraire.[...] En tout cas, il y a une chose curieuse, c'est de voir combien Swann, qui connaît tant de monde et du plus choisi, montre d'empressement auprès d'une société dont le moins qu'on puisse dire est qu'elle est fort mêlée."182

A primeira expressão de tom exclamativo Mon Dieu relacionada à prevalência da frequentação de senhores aponta para uma conotação ambígua, pois se refere tanto ao passado de Odette e sua ligação com muitos homens, quanto à inadequação do ambiente a senhoras respeitáveis. Ao corrigir-se e dizer que vão lá sim algumas mulheres, a qualidade destas é posta em dúvida, pois a primeira frase assertiva atenua a colocação hesitante da segunda. Portanto, a irrelevância delas é sentida tanto na informação dada mais appartenant plutôt (...) au monde républicain - estando o mundo burguês/republicano abaixo da nobreza, quanto na construção contraditória de M. de Norpois.

Em seguida, temos a antecipação do que viria a ser o salão mais tarde. Dada a origem da dona da casa, não será possível formar um grupo de grande relevância social, mas há a possibilidade de se escolher um viés afinado com a esfera artística, já que esta aceita com mais facilidade a diversidade de seus integrantes. Notemos, além disso, a observação do rebaixamento de Swann quanto ao nível de suas relações. Ora, fica clara a necessidade de tal ajuste, pois, para que Odette suba de patamar é necessário que Swann se adeque às novas possibilidades de relacionamento, deixando de

${ }^{182}$ À l'ombre des jeunes filles en fleurs, I, pp. 457, 458. 
lado o exclusivismo do faubourg Saint-Germain. Assim, através de sua influência, a esposa pode estabelecer conexões interessantes, mas não as impossíveis do círculo dos Guermantes.

Ainda, sob o ponto de vista evidentemente reprobatório do núcleo familiar do narrador a respeito de tal aliança, os comentários de sua mãe, apesar de tendenciosos e exagerados, revelam o empenho, por parte de Madame Swann, em formar seu grupo de habitués. Ao tomar conhecimento de cada nome de visita recebida pelo casal, ela expõe sua indignação. O texto simboliza a ironia de um grupo com tendência à estabilidade - a família de Marcel - diante da possível mobilidade ascendente de Odette. Vejamos alguns exemplos:

\footnotetext{
"Au nom de Mme Trombert, ma mère disait:

«Ah! mais voilà une nouvelle recrue et qui lui en amènera autres.»

Et comme si elle eût comparé la façon un peu sommaire, rapide et violente dont Mme Swann conquérait ses relations à une guerre coloniale, maman ajoutait:

« Maintenant que les Trombert sont soumis, les tribus voisines ne tarderont pas à se rendre. »

Quand elle croisait dans la rue Mme Swann, elle nous disait en rentrant:

« J'ai aperçu Mme Swann sur son pied de guerre, elle devait partir pour quelque offensive fructueuse chez les Masséchutos, les Cinghalais ou les Trombert. »"183
}

A insistência na escolha de palavras referentes ao universo bélico indica a dificuldade e o esforço despendido por Odette nos primeiros tempos. A crítica Raymonde Coudert assinala que o casamento é apenas uma das muitas

\footnotetext{
${ }^{183}$ À l'ombre des jeunes filles en fleurs, I, p. 506.
} 
etapas a serem vencidas por ela. ${ }^{184}$ Tais comentários, proferidos provavelmente em momentos distintos e apresentados no texto de forma encadeada, reproduzem o que seria o ritmo intenso e incansável de Odette na busca de novas conexões. Além disso, em uma obra cuja importância e função dos nomes próprios são imensas, a sequência de personagens obscuras e desconhecidas do leitor, citadas apenas ali, indica a insignificância do salão em sua origem. Assim como Sofia, Odette deve construir toda uma nova vida, da casa aos que a frequentam. ${ }^{185} \mathrm{O}$ suporte material do marido, nos dois casos, serve de alicerce para a edificação da rede de contatos, mas não a garante; o talento feminino em mantê-la é fundamental.

Odette vai amealhando conhecimentos, para que o texto do romance possa, em certa medida, repetir e ampliar o clã dos Verdurin. Assim, como em uma sinfonia - termo usado pelo autor -, os temas são apresentados e, posteriormente, desenvolvidos. Sempre estará presente o coro de vozes, cada uma apresentando uma visão da ascensão da personagem.

Nesse período de transição, a junção de vários aspectos da vida social do casal forma a unidade de sua existência. A casa, o modo de vestir-se e o comportamento de Madame Swann são aos poucos aprimorados, chegando a um equilíbrio entre o gosto requintado e original do marido e as predileções exóticas e questionáveis da mulher, as quais viriam a refinar-se dali a um tempo. Comecemos pela moradia:

\footnotetext{
${ }^{184}$ COUDERT, Raymonde, op. cit., p, 48: "Une étape seulement, pour celle qui continuera à gravir les durs dégrés de l'échelle sociale, de mariages en liaison, jusqu'au sommet, et juste avant la ruine du Faubourg Saint-Germain."

185 Quincas Borba, p. 761: "Nem todas as [novas] relações subsistiram, mas a maior parte delas estavam atadas, e não faltava à nossa dona o talento de as tornar definitivas."
} 


\begin{abstract}
"Toujours est-il que chaque fois que je pense à ce salon que Swann (sans que cette critique impliquât de sa part l'intention de contrarier en rien les goûts de sa femme) trouvait si disparate - parce que tout conçu qu'il était encore dans le goût moitié serre, moitié atelier qui était celui de l'appartement où il avait connu Odette, elle avait pourtant commencé à remplacer dans ce fouillis nombres d'objets chinois qu'elle trouvait maintenant un peu «toc », bien « à côté », par une foule de petits meubles tendus de vieilles soies Louis XVI (sans compter les chefs-d'oeuvre apportés par Swann de l'hôtel du quai d'Orléans)." ${ }^{186}$
\end{abstract}

Após o casamento, Swann e Odette passam a morar perto do Bois de Boulogne, tendo ele cedido à preferência dela em continuar próxima a seu antigo apartamento, pois, apesar de ser uma das novas regiões burguesas elegantes da cidade, não coincide com os meios por onde ele antes circulava. $^{187}$

A mistura de estilos e a modificação gradativa da decoração podem ser consideradas como o reflexo do aprimoramento da personagem. A substituição dos bibelôs chineses por móveis Luís XVI indica o abandono da antiga cocotte da febre orientalista pequeno-burguesa em prol de um estilo considerado sofisticado e mais condizente ao gosto aristocrático. ${ }^{188}$ Tal alteração se deve à necessidade de inserção no tradicional, ou seja, para ascender Odette deverá

\footnotetext{
${ }^{186}$ À l'ombre des jeunes filles en fleurs, I, pp. 529, 530.

187 SAIKI, Shinichi, op. cit., p. 32: "Malgré cette que l'on peut observer entre les lieux d'habitation des amants, ils s'installent après le mariage dans le quartier du Bois, Swann s'adaptant au goût de sa femme. II faut bien remarquer que l'avenue du Bois, haut lieu de l'élégance du nouveau Paris de Haussmann, se trouve tout près de la rue La Pérouse."

${ }^{188}$ À l'ombre des jeunes filles en fleurs, I, pp. 604, 605: "D'ailleurs dans le désordre artiste, dans le pêle-mêle d'atelier, des pièces aux murs encore peints de couleurs sombres qui les faisaient aussi différents que possibles des salons blancs que Mme Swann eut un peu plus tard, I'Extrême-Orient reculait de plus en plus devant l'invasion du XVIIIle siècle".
} 
adaptar-se ao ponto de vista cultural pré-existente, visto que esses tipos de mobília pertencem a uma velha tradição das famílias francesas.

A transformação no vestuário também é bastante significativa. A esse respeito, Judith Oriol assinala:

"L'élégance et la mode rejoignent chez Proust la psychologie puisque même les vêtements prennent sens et deviennent discours par une métonymie qui leur permet de prolonger l'esprit de celle qui les porte." ${ }^{189}$

Vejamos como a observação se aplica à configuração da personagem. Apesar de não cessar o hábito de receber os mais íntimos em robes de quarto, nos primeiros tempos ela os tinha em cores quentes e fortes, combinando-os à ambientação dos cômodos da casa. Não muito tempo depois, ela passa para uma fase toda clara na qual suas vestimentas e salões são predominantemente brancos. Observemos duas passagens exemplares de tal mudança:

"Elle allait s'habiller aussi, bien que j'eusse protesté qu'aucune robe « de ville » ne vaudrait à beaucoup près la merveilleuse robe de chambre de crepe de Chine ou de soie, vieux rose, cerise, rose Tiepolo, blanche, mauve, verte, rouge, jaune, unie ou à dessins, dans laquelle Mme Swann avait déjeuné et qu'elle allait ôter." 190

"Maintenant c'était plus rarement dans des robes de chambre japonaises qu'Odette recevait ses intimes, mais plutôt dans les soies claires et mousseuses de peignoirs Watteau desquelles elle faisait le geste de caresser ses seins l'écume fleurie, et dans lesquelles elle se baignait [...] avec un tel air de bien-être, de rafraîchissement de la peau [...] pour contenter les

\footnotetext{
${ }^{189}$ ORIOL, Judith. Femmes proustiennes. Bucarest: EST, 2009, p. 216.

${ }^{190}$ À l'ombre des jeunes filles en fleurs, I, p. 531.
} 
exigences de sa physionomie et le raffinements de son hygiène." 191

No primeiro extrato, dentre a enumeração de oito cores, apenas duas, o verde e o branco, não se enquadram na gama de cores quentes. Os tons avermelhados remetem ao apartamento da Rua de La Pérouse e sua ornamentação, além de aludirem significativamente à sensualidade e à vida levada por ela antes do enlace. Do mesmo modo, a insistência nos vários tons de cor-de-rosa, marca registrada de Odette desde sua primeira aparição como a dame en rose, indica a presença de reminiscências dos hábitos antigos na nova residência.

Passando à segunda citação, temos a impressão de que Odette procura apagar sua condição de cocotte. Da variação de tonalidades fortes passamos à homogeneidade dos tons alvos. Podemos observar também que a escolha de várias palavras alusivas à água - mousseuses, l'écume, baignait, refraîchissiment - e a menção aos peignoirs Watteau, cujos plissados aludem às ondas, convergem para a sensação de higiene referida pelo narrador, como se essa limpeza fosse necessária à aceitação social. Contudo, o caminho da ascensão ainda será longo e penoso, pois a filha terá de passar pelo nome do padrasto antes de ser recebida pelos Guermantes.

Mantendo, nos primeiros anos de casada, um salão mediano frequentado por Madame Cottard e Madame Bontemps, futuramente celebrada, mas nesse tempo desprestigiada, Madame Swann tem a chance de estabelecer recepções de boa qualidade com a assiduidade do consagrado

\footnotetext{
${ }^{191}$ Idem, p. 605.
} 
escritor Bergotte. Será nos jantares em torno dele que Odette poderá mostrar seu savoir-faire de anfitriã:

"Pour se mêler à la conversation, Mme Swann me demanda si Gilberte avait pensé à me donner ce que Bergotte avait écrit sur Phèdre. [...] Bergotte eut un sourire de modestie et protesta que c'était des pages sans importance. "Mais si, c'est ravissant ce petit opuscule, ce petit tract », dit Mme Swann pour se montrer bonne maîtresse de maison, pour faire croire qu'elle avait lu la brochure, et aussi parce qu'elle n'aimait pas seulement complimenter Bergotte, mais faire un choix entre les choses qu'il écrivait, le diriger. [...] Mais enfin il y a entre ce que fut l'élégance du salon de Mme Swann et tout un côté de l'oeuvre de Bergotte des rapports tels que chacun des deux peut être alternativement pour les vieillards d'aujourd'hui, un commentaire de l'autre." ${ }^{192}$

A presença de Bergotte nos domínios dos Swann tem a função de eleválos e chancelá-los. Eles se alçam a um patamar imediatamente abaixo da alta aristocracia - cette classe intermédiaire, inférieur au faubourg Saint-German, puisqu'elle le courtisait, mais supérieur à ce qui n'est pas du faubourg SaintGermain ${ }^{193}$ - , sem poder, todavia, misturar-se a ela. Se, em Quincas Borba, as visitas de um deputado e de um diretor de banco são suficientes para alavancar a posição do casal na sociedade fluminense, no contexto francês, bem mais hierarquizado, faz-se necessário o intercâmbio com indivíduos mais renomados. Por isso, o caminho em direção ao reconhecimento, a exemplo do salão Verdurin, constrói-se também por meio do verniz cultural. Tal interação ocorre de modo a satisfazer os interesses de ambos os lados, pois Odette pode exibir sua habilidade em receber ao mesmo tempo em que Bergotte e seus textos podem ser apreciados. Se os convidados de Madame Swann têm brilho

\footnotetext{
${ }^{192}$ À l'ombre des jeunes filles en fleurs, I, p. 551.

193 Idem, p. 628.
} 
menor, o escritor o tem enorme e o próprio narrador o admira. Ele pode ser visto como o primeiro valor real a se inserir na nova vida de Odette.

A partir daí, como se o frequentador ilustre tivesse derrubado obstáculos antes intransponíveis, nomes antes figurados apenas no meio dos Guermantes, começam a ser notados nesse espaço emergente, ora por uma visita do príncipe d'Agrigente ${ }^{194}$ (visto nas soirées de Madame Sainte-Euverte e da duquesa de Guermantes), ora pelos cumprimentos do príncipe de Sagan e de Adalbert de Montmorency, pertencente ao primeiro baronato da França, durante as excursões públicas da família Swann no Bois de Boulogne ${ }^{195}$. Desse modo, a intensificação da comunicação entre as duas esferas se torna irreversível.

Seja na mobília, no vestuário, nos gestos ou, principalmente, nos convivas, o texto insiste constantemente no aspecto de mudança. Portanto, a estabilidade se esfuma. Decidida a ascensão, o ritmo será diferente, cada vez mais rápido, pois a trajetória se organiza em direção a um foco preciso. Aos comentários detalhados acerca das várias transformações das personagens somam-se as observações aguçadas da mãe do narrador num procedimento semelhante ao visto em Quincas Borba no discurso do Major Siqueira. Ao dar voz a quem está em volta, sobretudo a figuras estáveis, o texto consegue adensar a noção mesma de mudança, percebida por quem não faz parte dela.

\footnotetext{
${ }^{194}$ À l'ombre des jeunes filles en fleurs, I, p. 589.

195 Idem, pp. 628, 629.
} 
Os Guermantes e a tradição aristocrática

Depois da temporada de reuniões na casa dos Swann, adentraremos, junto ao narrador, outros dois tipos do universo mundano: a nobreza, por meio das recepções dos duques e dos príncipes de Guermantes e a burguesia dominante, no jantar musical de Madame Verdurin. Interessa-nos aqui abordar paralelamente tais eventos assim como o fizemos ao acompanhar Swann no primeiro salão Verdurin e na festa de Madame de Sainte-Euverte no capítulo II.

Do mesmo modo que percebemos através do olhar de Charles Swann o contraste entre os ambientes analisados anteriormente, apreenderemos, na medida em que Marcel o faz, as particularidades desses outros recintos.

Ao relatar sua primeira visita ao duque e à duquesa de Guermantes, o protagonista descreve os modos do anfitrião com o intuito de demonstrar a categoria à qual pertence tal conjunto de pessoas:

"Fort peu Ancien Régime quand il s'efforçait ainsi de l'être, le duc le redevenait ensuite sans le vouloir. M'ayant demandé si je désirais qu'il me montrât ces tableaux, il me conduisit, s'effaçant gracieusement devant chaque porte, s'excusant quand, pour me montrer le chemin, il était obligé de passer devant, petite scène qui (depuis le temps où Saint-Simon raconte qu'un ancêtre des Guermantes lui fit les honneurs de son hôtel avec les mêmes scrupules dans l'accomplissement 
des devoirs frivoles du gentilhomme) avait dû avant de glisser jusqu'à nous, être jouée par bien d'autres Guermantes pour bien d'autres visiteurs." 196

Por meio da descrição da conduta do nobre, somos informados da maneira de agir de toda uma classe e não de um indivíduo apenas. Os movimentos ocorrem como se seguissem rigorosamente uma coreografia concebida e aperfeiçoada ao longo de séculos. Os termos petite scène e jouée reforçam a impressão teatral. Já o recuo temporal, à época em que SaintSimon relata semelhante cena dois séculos antes, revela a perenidade histórica da família. ${ }^{197}$ Do mesmo modo, a expressão autres Guermantes seguida por autres visiteurs demonstram a preponderância da linhagem sobre um indivíduo específico, como se o nome determinasse o porte de quem o carrega. Não podemos deixar de atentar, também, a um detalhe significativo. As telas de Elstir expostas ali indicam uma abertura, mesmo que pequena, de um recinto ainda muito ligado ao Ancien Régime a algo contemporâneo, como se alguma renovação fosse inevitável. Além disso, a constatação do acerto artístico de Madame Verdurin fica evidente, visto que ela havia promovido o pintor duas décadas antes. Tal fato representa, no tocante ao tema, um dos primeiros sinais da futura inserção de um grupo no outro.

Esse tipo de recepção cerimoniosa se repete na festa do príncipe e da princesa de Guermantes:

\footnotetext{
${ }^{196}$ Le Côté de Guermantes, p. 712.

${ }^{197}$ Le Côté de Guermantes, p. 722: "Dans une partie importante de l'aristocratie [...] ce trait de caractère a cessé d'être individuel; cultivé par l'éducation, entretenu par l'idée d'une grandeur propre qui ne peut craindre de s'humilier, qui ne connaît pas de rivales, sait que par l'aménité elle peut faire des heureux et se complaît à en faire, il est devenu le caractere générique d'une classe."
} 
"Mais maintenant les invités de la soirée commençaient d'arriver et la maîtresse de maison s'était assise non loin de l'entrée - droite et fière, dans sa majesté quasi royale, les yeux flambant par leur incandescense propre - entre deux altesses sans beauté et l'ambassadrice d'Espagne." ${ }^{198}$

O modo com que a princesa recebe seus convidados - sentada entre outras altezas - revela ainda maior rigor na hierarquização social que os gestos do duque, pois ela reproduz quase fielmente os hábitos da corte. Há um sentimento misto de estranhamento e encanto frente a um ritual tão anacrônico, como se o narrador estivesse vivenciando os últimos suspiros de uma era. Por ser um outsider em relação à nobreza, malgrado a ligação com os Guermantes, ele se encontra em posição que facilita a percepção desse tipo de ironia.

Nos dois momentos destacados acima, a voz narrativa oferece mais que personagens individuais - o que se vê são símbolos sociais: Ancien Régime, Saint-Simon, d'autres Guermantes, majesté quasi royale. A escolha de tais termos implica a configuração de uma situação permanente, de quase paralisia social. O estabelecimento desse cenário se faz necessário, pois a busca do arrivista de superação do imobilismo consistirá justamente em conviver, ainda que de modo subversivo, com as regras rígidas em tal contexto.

Temos, portanto, uma oposição entre a estabilidade da nobreza gestual, mobiliária e cultural - e a mobilidade, que é a tônica do arrivismo tentativa e erro social, espaço (casa) novo -, representada pelo esforço de Odette e Madame Verdurin. O narrador se demora textualmente nas mudanças dos arrivistas, assim como nos rituais da nobreza - o duque e os quadros, a

\footnotetext{
${ }^{198}$ Sodome et Gomorrhe, p.36.
} 
posição da princesa na festa. Por pertencer ao núcleo de Combray, o único que não sofre transformações sociais causadas pela ação do tempo e da História, representando uma espécie de paraíso perdido, ele se dedica à observação dos grupos passíveis de mudanças, mesmo que elas, nesse momento, não sejam evidentes.

Evolução do salão Verdurin

Passemos, agora, à fase intermediária de Madame Verdurin no romance. Ao ocupar a propriedade La Raspelière dos Cambremer, pequenos nobres de província, ela mimetiza o costume da aristocracia de transferir-se ocasionalmente para as propriedades campestres. A importância de se manter a ligação com a terra de origem é fundamental para a nobreza, pois de sua posse provêm seus títulos geralmente homônimos a ela. Por isso, a Patronne encontra uma forma precária e canhestra de preencher essa lacuna. ${ }^{199}$ Tendo alcançado uma nova etapa rumo ao reconhecimento, a conjunção é distinta daquela inicial da Rua Montalivet:

"J'avais oublié que les Verdurin commençaient vers le monde une évolution timide, ralentie par l'affaire Dreyfus, accélérée par la musique «nouvelle», évolution d'ailleurs démentie par eux, et qu'ils continueraient de démentir jusqu'à

\footnotetext{
${ }^{199}$ A questão da posse da terra é muito simbólica, pois remonta às origens tradicionais da família, como é o caso dos Guermantes. Já a família Verdurin é exclusivamente parisiense, não pertencendo a nenhuma linhagem sucessória. A esse respeito ver SAIKI, Shinichi, op. cit. p., 74.
} 
ce qu'elle eût abouti, comme ces objectifs militaires qu'un général n'annonce que lorsqu'il les a atteints, de façon à ne pas avoir l'air battu s'il les manque. Le monde était d'ailleurs, de son côté, tout préparé à aller vers eux. [...] Le salon passait pour un temple de la musique. C'était là, assurait-on, que Vinteuil avait trouvé inspiration, encouragement. Or si la sonate de Vinteuil restait entièrement incomprise et à peu près inconnue, son nom, prononcé comme celui du plus grand musicien contemporain, exerçait un prestige extraordinaire." 200

A analogia entre as estratégias de guerra e o processo que caracteriza o arrivismo, vista na movimentação de Madame Swann, reaparece aqui. Ao declarar-se dreyfusarde, Madame Verdurin opta por um caminho mais arriscado, pois toda a aristocracia e a alta burguesia aspirante a alcançá-la como é o caso de Odette - tomam o partido oposto alinhado com o nacionalismo resgatado após a guerra franco-prussiana.

Todavia, a escolha, apesar de perigosa, revelar-se-á muito mais eficaz com a revisão e o desfecho do caso, inocentando Dreyfus. ${ }^{201}$ A grande capacidade de antecipação política e artística pauta todo o percurso de Madame Verdurin. Seu salão, assim como o dos Swann, ganha notoriedade com a presença de personalidades em destaque, com a diferença de apostar nelas muito antes de terem alcançado qualquer visibilidade. A pintura de Elstir e a música de Vinteuil são celebradas desde os primeiros tempos pelo pequeno clã. Tendo percebido que a mudança social iria de par com as

\footnotetext{
${ }^{200}$ Sodome et Gomorrhe, p. 263.

${ }^{201}$ A esse respeito Judith Oriol assinala: "À l'époque de l'Affaire, malgré son «antisémitisme bourgeois», elle va faire le choix de se ranger dans le clan des dreyfusards et va même lancer la mode intellectuelle qui consiste à organiser de «véritables séances de Salut Public» en réunissant Picquart, Clémenceau, Zola, Reinach et Labori. Mais son choix semble plutôt guidé par un snobisme républicain et anticlerical que par un réel souci de justice et de vérité. Malgré «l'énorme retard que l'erreur mondain de l'affaire Dreyfus lui avait infligé», elle finira en définitive par lui rendre service.", op. cit. p., 238.
} 
renovações da política e da arte, os passos de Madame Verdurin são meticulosamente calculados, de modo que o apoio a Dreyfus e o incentivo à arte vanguardista se configuram mais como decisão objetiva que subjetiva, mesmo que o apreço a eles seja verdadeiro. ${ }^{202}$

A maturação desse salão se dá por meio de mudanças aparentemente contraditórias, mas pertinentes e necessárias à sua elevação. Seus habitués se adaptam ao modo elegante de vestir-se da elite parisiense, mas mantêm a informalidade no comportamento a exemplo da dona da casa ao recebê-los, como exemplificam as passagens abaixo:

"Je ne m'étais pas rendu compte à quel point le petit clan ayant façonné tous les «habitués» sur le même type, ceux-ci, par surcroît en grande tenue de dîner, attendant sur le quai, se laissaient tout de suite renconnaître à un certain air d'assurance, d'élégance et de familiarité [...]"203

"Mme Verdurin qui, pour nous recevoir dans son immense salon, où des trophées de graminées, de coquelicots, de fleurs de champs, cueillis le jour même, alternaient avec le même motif peint en camaïeu, deux siècles auparavant, par un artiste d'un goût exquis, s'était levée un instant d'une partie qu'elle faisait avec un vieil ami, nous demanda la permission de la finir en deux minutes tout en causant avec nous." 204

${ }^{202}$ Concordamos aqui com Marion Schmid: "Certes, les Verdurin sont de ferventes amateurs de Wagner, compositeur fort contesté de la fin de siècle et ce sont eux qui ont lancé le peintre Biche qui, dans la deuxième partie de sa vie, devient le maître vénéré Elstir. Mais, une fois de plus, leur intérêt pour les artistes progressistes semble relever avant tout d'un phénomème de mode et d'un désir de se détacher de la masse commune des «ennuyuex» qui, eux, aiment les artistes plus conservateurs.", Proust dans la décadence. Paris: Honoré Champion Éditions, 2008, p. 110.

203 Sodome et gomorrhe, p. 259.

${ }^{204}$ Idem, p. 296. 
Quase todas as informações da primeira passagem se opõem às do salão inicial dos Verdurin. Enquanto lá o fraque era proibido, aqui todos estão vestidos em traje de gala para uma reunião na província. Também a segurança e os modos elegantes não lembram em nada o jeito desastrado de Brichot e a falta de senso crítico e discernimento dos comentários de Cottard. Este, tendo se tornado professor de medicina, adquire fama de grande sábio; aquele passa a ser invejado pelos colegas da Sorbonne e vê aumentar sua reputação entre seus pares por frequentar ambiente tão inovador.

Outro ponto a ser notado é a homogeneidade estética e espiritual do grupo, pois, como já foi dito, ele evolui em bloco. ${ }^{205}$ As aparições das personagens pertencentes ao clã são constituídas de forma a propiciar sempre a ideia de coletividade. Daí o uso maciço de diálogos entre elas, piadas internas e o aspecto grupal das viagens de trem para a Raspelière.

Também não passa despercebida a informalidade da anfitriã, pois o à-vontade com que interrompe o jogo de cartas para receber os convidados destoa da forma altiva e solene da princesa de Guermantes. Percebemos o aperfeiçoamento desse salão por meio da mudança de alguns hábitos, como a adoção do traje a rigor, e da manutenção de outros, a exemplo da camaradagem entre os convivas. Nesse sentido, Madame Verdurin parece buscar um equilíbrio entre a rigidez da postura aristocrática e o frescor da modernidade burguesa de forma a melhor adequar-se aos novos tempos. Tudo isso, filtrado por uma voz narrativa que executa sua aprendizagem do mundo

\footnotetext{
${ }^{205}$ Catherine Bidou-Zachariasen comenta a ascensão conjunta do grupo: "Le salon évoluera avec eux et leurs résussites individuelles comme ils évolueront à travers lui, à travers les goûts et les choix éclectiques de la Patronne.", op. cit., p. 16.
} 
social, entremeando lições afetivas e prática de convivialidade. Registre-se o conúbio resultante dos destinos individuais e o avanço social e profissional do grupo.

No que diz respeito ao tipo de conhecimento cultivado em um e outro universo, o cotejo das cenas análogas dos discursos genealógico e etimológico do duque de Guermantes e de Brichot, respectivamente, interessa à nossa análise.

Ao ser perguntado sobre o parentesco entre o príncipe Von e o duque d'Aumale, Monsieur de Guermantes responde: Parce que le frère de sa mère, le duc de Wurtemberg, avait épousé une fille de Louis-Philippe ${ }^{206}$, e, mais adiante, para explicar a relação familiar com Madame Arpajon: [ il ] était obligé, si loin et si simplement, de remonter, par la chaîne et les mains unies de trois ou cinq aïeules, à Marie-Louise où à Colbert [..]. ${ }^{207}$ As muitas páginas de Le Côté de Guermantes dedicadas às elucidações do duque acerca das conexões da nobreza têm função de demonstrar os preceitos sobre os quais tal grupo se apoia. A demanda de legitimidade por meio do sangue e do casamento, ilustrada por nomes e títulos, nos causa certa sensação de anacronismo, como se essa época não pudesse se estender por um longo período, ao mesmo tempo em que nos ancora mais profundamente na matéria viva da ascensão de personagens como Odette e Madame Verdurin que não deixarão, no fim da obra, de orbitar em torno dos Guermantes.

Tais lances permitem que a narrativa se vincule ainda mais à história da França, adensando o tempo, que não se mostra apenas individual,

\footnotetext{
${ }^{206}$ Le Côté de Guermantes, p. 825

${ }^{207}$ Idem, p. 826.
} 
mas alcança o coletivo da vida do país, com seus heróis e figuras de proa, diferentemente da atmosfera íntima das personagens machadianas.

O peso da tradição tem grande valor na sociedade estratificada reconstruída pela memória do narrador, assim como o fato de a burguesia ascendente tomar de assalto os bens imateriais da nobreza - Madame Verdurin torna-se princesa.

Em Sodome et Gomorrhe, as passagens das etimologias de Brichot ecoam as da genealogia do duque de Guermantes. As colocações do professor a respeito da gênese da designação das várias cidades e regiões remetem o leitor atento àquela recepção dos Guermantes:

"Or donc, continua Brichot, bec en normand est ruisseau; il y a l'abbaye du Bec; Mobec, le ruisseau du marais (mor ou mer voulait dire marais comme dans Morville, ou dans Bricquemar, Alvimare, Cambremer); Bricquebec, le ruisseau de la hauteur, venant de briga, lieu fortifié, comme dans Bricqueville, Bricquebosc, Le Bric, Briand [...]" 208

Assim como a enumeração de figuras ilustres pelo duque poderia reproduzir um livro de história da nobreza francesa, a fala acadêmica do erudito se assemelha ao conteúdo de um dicionário ou de uma enciclopédia, inclusive pela repetição de muitos nomes iniciados pela letra "b". Enquanto o domínio das informações de filiação é necessário para legitimar o pertencimento à aristocracia e as vantagens decorrentes dele, o conhecimento de Brichot é fundamental no meio em que as habilidades profissionais são celebradas. ${ }^{209}$

\footnotetext{
${ }^{208}$ Sodome et Gomorrhe, p. 328.

${ }^{209}$ Antoine Compagnon analisa detalhadamente as etimologias de Brichot no ensaio "Brichot: étymologie et allégorie" em seu Proust entre deux siècles. Paris: Éditions du Seuil, 1989.
} 
Portanto, cada núcleo social distinto se dedica à manutenção do código cultural que Ihe convém, o que se acrescenta em Proust, à presença maciça de dados, ao contrário do narrador machadiano, que, apenas de modo paródico, instaura nas narrativas a figura e as ponderações finalistas do filósofo Quincas Borba, criticando, desse modo, os "ismos" cientificistas do século XIX.

Retornando ao aperfeiçoamento de Madame Verdurin, notamos que tal transição não ocorre sem alguns percalços. Se, no aspecto do senso estético sua evolução é inquestionável, não podemos dizer o mesmo da desenvoltura no trato social. Ao receber os marqueses de Cambremer e o barão de Charlus, a inexperiência dos anfitriões acerca da hierarquia nobiliárquica fica evidente na narração cômica de suas atitudes equivocadas a ponto de o barão exclamar: J'ai tout de suite vu que vous n'aviez pas l'habitude. ${ }^{210}$ A supracitada sequência de gafes dos Verdurin, dentre as quais a ignorância da primazia social de Charlus e seu preterimento em favor do marquês ${ }^{211}$, explicita o completo desconhecimento do faubourg Saint-Germain e revela a real intenção de penetrá-lo, visto que o casal se preocupa em reproduzir regras de etiqueta aristocráticas.

Constatamos, desse modo, a coexistência de um discurso oficial e de uma vontade verdadeira. ${ }^{212}$ Os Verdurin e seus compartes simulam

\footnotetext{
210 Sodome et Gomorrhe, p 333.

${ }^{211}$ Idem.

212 A esse respeito ver o ensaio de Leo Spitzer, "Le style de Marcel Proust", no qual o crítico demonstra como a hesitação de Madame Verdurin ao pronunciar ou não a partícula "de" ao referir-se à Madame de La Trémoille revela a veracidade da intenção de seu discurso: "De même que la psychologie moderne construit des appareils de détection du mensonge, Proust compare le ton et le discours, et décèle le démenti sous le "mensonge" du second. Parfois le
} 
indiferença diante da elite, mas deixam transparecer o julgamento sincero nos instantes de distração, como denunciam as palavras repetidas e transcritas de Cottard, não sem certa dose de ironia, por um narrador atento às especificidades de cada grupo: Où ça, un baron? Où ça, un baron? ${ }^{213} A p e s a r$ de não conhecerem bem os rituais do comportamento aristocrático e aparentarem não respeitá-los, tentam repeti-los em seu salão, mas o fazem, às vezes, de forma desastrosa. Assim, observamos a movimentação de Madame Verdurin num jogo de avanços e recuos, acertos e erros, no qual tenta encontrar equilíbrio entre a inserção de novidades e a assimilação e manutenção de tradições caras à nobreza.

mensonge intérieur déborde sur le langage direct - aussitôt reconnu par le moraliste et le grammairien.", Études de style. Paris: Éditions Gallimard, 1970, p. 438.

${ }^{213}$ Sodome et Gomorrhe, p. 303. 


\section{Capítulo IV}

\section{Consolidações}

Être 'quelque chose' signifie tenir son rôle: non point arbitraire, quelconque, mais celui qui s'offre à des aspirations légitimes et sanctionne des compétences prouvées.

Michel Guérin, La grande dispute ${ }^{214}$

A conquista de Guiomar

Desde os primeiros capítulos de $A$ mão e a luva, percebemos que o casamento constitui o ponto de referência para o qual se direciona a narrativa. A primeira cena em que Estêvão espreita Guiomar bem como as subsequentes descrições contrastantes do par apontam para o advento de outros pretendentes, visto que a resolução de tal questão - o casamento - se configura como passo principal na trajetória das moças nesse tipo de sociedade. ${ }^{215}$ Assim, o movimento do texto não se constrói em torno da realização do matrimônio - pois é colocado como fato provável -, mas da habilidade da protagonista em escolher quem julga mais adequado para si em meio às vicissitudes da trama, já que precisa administrar a vontade da

${ }^{214}$ GUÉRIN, Michel. La grande dispute. Essai sur l'ambition, Stendhal et le XIXe siècle. Actes Sud, 2006, p. 168.

${ }^{215}$ STEIN, Ingrid, op. cit., pp. 30-32. 
madrinha, os ardis de Mrs Oswald e dos pretendentes, além da tomada de decisão de Luís Alves.

Nos dois primeiros terços do romance, o narrador se dedica a descrever Estêvão e Jorge de forma evidentemente opositiva a Guiomar para preparar o encontro harmônico com o último pretendente na parte final da obra. A constituição de Luís Alves se apresenta quase como um espelho dos traços da heroína, fazendo com que a identificação do casal seja imediata. A fórmula usada anteriormente para apresentar a personalidade de Guiomar se repete na caracterização do advogado:

"O coração era capaz de afeições; mas, como ficou dito no primeiro capítulo, ele sabia regê-las, moderá-las, guiá-las ao seu próprio interesse. Não era corrupto nem perverso; também não se pode dizer que fosse dedicado nem cavalheiresco; era, ao cabo de tudo, um homem friamente ambicioso." ${ }^{216}$

A passagem acima faz lembrar as palavras do narrador ao referir-se à postura da protagonista. Tal procedimento reforça a concordância inquestionável entre os dois espíritos. Percebemos a insistência na escolha de termos similares, assim como na estrutura de sentenças concessivas, pois há sempre uma afirmação seguida de atenuação ou negaceio. O trecho repleto de ponderações expressas por construções contrastantes como afeição/interesse e dedicado/perverso ecoa a seguinte observação do narrador: "Guiomar não tinha uma coração tão mau, que lhe não doessem as mágoas de um homem que acertara ou desacertara de a amar."217

\footnotetext{
${ }^{216}$ A mão e a luva, p. 257.

217 Idem, p. 228.
} 
Desse modo, o tom de discordância entre a heroína e os demais se transforma em completa concordância com o aparecimento efetivo de um par que "ia muito com o gênio de Guiomar". ${ }^{218}$ Constatamos no texto a passagem de uma inclinação individual, a da moça, ao projeto do casal, com o advento de Luís Alves. ${ }^{219}$ Ora, tal encaminhamento é necessário, pois a mulher só poderia desfrutar de prestígio apoiada nos sucessos profissionais ou políticos do marido, conforme já assinalamos. Apesar das restrições sociais impostas à época, sua função era extremamente relevante na consideração pública da família.

Doravante, a constituição do texto far-se-á toda por passagens duplicadas que se olham e se reconhecem, intensificando progressivamente o entendimento do par, como atestam os exemplos abaixo:

"[...] e foi, sem dúvida, a primeira ocasião em que sentiu que a amava deveras, ainda que o seu amor fosse como ele mesmo: plácido e senhor de si." 220

"Guiomar amava deveras. Mas até que ponto era involuntário aquele sentimento? Era-o até o ponto de lhe não desbotar à nossa heroína a castidade do coração, de lhe não diminuirmos a força de suas faculdades afetivas, Até aí só; daí por diante entrava a fria eleição do espírito."221

\footnotetext{
${ }^{218}$ A mão e a luva, p. 245.

${ }^{219}$ A esse respeito Helen Caldwell comenta: "[...] the novel is concerned with "will" - will in the Stendhalian sense. Hand and glove contains no less than two Julien Sorels: one male, one female. If Stendhal's Sorel was a travesty of Napoleonic hero, Guiomar and Luís are little in Sorels." In Machado de Assis. The Brazilian Master and his novels. University of California Press, 1970, p. 44.

${ }^{220}$ A mão e a luva, pp. 251, 252.

${ }^{221}$ Idem, p. 253.
} 
Além disso, o estabelecimento do acordo entre o casal segue a mesma fórmula de diferençar a protagonista dos primeiros candidatos ao casamento, continuada pelo contraste entre o eleito e os anteriores. Afastandose do sentimentalismo desmesurado de Estêvão e da inércia indiferente de Jorge, duas posturas que riscam o comprometimento com o lustre profissional e social, Luís Alves configura-se como a melhor opção. Note-se que o texto se constrói em dois eixos: de um lado, o paralelismo das situações referentes a Guiomar e Luís Alves, sobretudo no que se refere à energia e à vontade de vencer; de outro, a pouca inserção social positiva e frutífera dos demais pretendentes. Desse modo, a identificação entre o par stendhaliano e o contraste com a ineficiência das outras personagens convergem para o fim da trama: a mão e a luva que se atraem, feitas uma para a outra.

Decidida por aquele que "Ihe falava ao coração"222, resta ainda a dificuldade de realizar seu desejo sem "tirar as esperanças à baronesa". ${ }^{223} \mathrm{~A}$ forma pela qual Guiomar decide solucionar o problema ocorre em duas etapas cujo objetivo é o mesmo: fazer com que os outros profiram as palavras de sua vontade e não ela própria, mantendo-se recatada e adequada à situação vigente, além de aparentar submissão à madrinha. Primeiro, ela faz com que a baronesa saiba de sua intenção por Luís Alves:

"[...] veio-lhe ao espírito uma ideia decisiva, a de confessar tudo à madrinha. Hesitou, porém, entre fazê-lo ela própria ou por boca de Luís Alves [...]. Preferiu este meio [...]"224

\footnotetext{
${ }^{222}$ A mão e a luva, p. 260.

223 Idem.

224 Idem, p. 261.
} 
Do mesmo modo, ao responder ao questionamento de sua provedora sobre a preferência entre Jorge e Luís Alves, lança mão da eficaz estratégia de dizer com grande pesar o nome do sobrinho, revelando pelo olhar a falsidade da afirmação. A força de tal manobra está no fato de convergir a um só tempo a verdadeira intenção de Guiomar e a demonstração de respeito pela vontade da madrinha. Como o narrador aponta, em diálogo direto com o leitor para chamar sua atenção, quem dá a palavra final, após a hábil condução da protagonista para esse desfecho, é a baronesa:

"_Escolhes o outro? Pois casarás com ele.

Vê o leitor que a palavra esperada, a palavra que a moça sentia vir-lhe do coração aos lábios e querer rompê-los, não foi ela quem a proferiu, foi a madrinha; e se leu atento o que precede verá que era isso mesmo o que ela desejava."225

Devido à fragilidade da posição de dependência em que se encontra, a inteligência da personagem se revela na expressão de uma postura oposta à que nutre na intimidade. A altivez do espírito é velada por demonstração de humildade e a ambição se esconde no possível sacrifício (de casar-se com Jorge para satisfazer a baronesa), de maneira que a suposta preponderância do amor à nova mãe em detrimento da realização de seus desejos constitui o artifício mais eficiente nesse contexto hierarquizado.

Outra questão interessante a permear a narrativa, a da junção da natureza à sociedade, ou seja, do sentimento à união vantajosa, encontra sua forma mais exemplar e expressiva no último capítulo. Este, cujo título "Conclusão" resume a trama, recuperando seu fio condutor de harmonia entre o íntimo e o social, se compõe da descrição da chácara como extensão das

\footnotetext{
${ }^{225}$ A mão e a luva, p. 265.
} 
personagens, indo de par com as figuras que querem flores bonitas, mas em vaso de Sèvres e felicidade conjugal atrelada ao sucesso político:

\begin{abstract}
"A manhã daquele dia trajava um manto de neblina cerrada, que o nosso inverno the pôs aos ombros, como para resguardá-la do rigor benigno da temperatura, manto que ela sacudiu dali a nada, a fim de mostrar qual era, uma deliciosa e fresca manhã fluminense. Não tardou que o sol batesse de chapa nas águas tranquilas e azuis, e nessas colinas onde o verde natural ia alternando com a alvura das habitações humanas. Vento nenhum; apenas uma aragem, branda e fresca, que parecia o último respirar da noite já remota, e que só a trechos agitava as folhas do arvoredo."226
\end{abstract}

A primeira impressão da imagem puramente bucólica desvela aos poucos os traços centrais de Guiomar e Luís Alves, como se a natureza se fundisse às características humanas. As "águas tranquilas" e a "aragem branda e fresca" aludem claramente ao temperamento comedido e prático do casal, da mesma forma que a harmonia entre "o verde natural" e a "alvura das habitações" recupera os anseios de Guiomar em obter tanto "as afeições domésticas"227 quanto "o ruído exterior"228. Não esqueçamos que Machado procurar estabelecer os contornos de caracteres sem os excessos românticos, apresentando um tipo de amor brando e consciente, nem por isso menos "verdadeiro". A cena acima é toda encanto, inclusive porque a homogeneidade na suavidade do tom contrasta com a maior parte do romance. A tensão presente em quase todo o decorrer do enredo entre Guiomar e todos que a cercam - Mrs Oswald, Estêvão, Jorge e até a madrinha - desaparece com a

\footnotetext{
${ }^{226}$ A mão e a luva, p. 268.

${ }^{227}$ Idem, p. 254.

${ }^{228}$ Idem.
} 
resolução do imbróglio matrimonial. O paradoxo "rigor benigno da temperatura", tão apropriado para descrever a protagonista, aparece para lembrar a sua constituição - toda edificada sobre oposições desse tipo -, mas esvai-se rapidamente para dar lugar a uma existência coerente com sua vontade e conquistada não sem dificuldade.

Nesse mesmo sentido, resolve-se por completo a relação com a baronesa a partir da concessão do casamento:

"O casamento fez-se, enfim. As lágrimas que a baronesa derramou, quando viu Guiomar ligada para sempre, foram as mais belas joias que lhe podia dar. Nenhuma mãe as verteu mais sinceras; e, seja dito em honra de Guiomar, nenhuma filha as recebeu mais dentro do coração."229

A "tática"230 e a "afetação"231 deixam de ser necessárias, pois, tendo recebido tal consentimento, o status da relação entre "mãe" e "filha" é consolidado. Além disso, como mulher casada, Guiomar adquire independência de sua mantenedora da forma mais consensual possível, fazendo com que o afeto possa se intensificar como sentimento verdadeiro e se atenuar como "encarecimento voluntário". 232

Em ponto pequeno, portanto, segundo a lição de Helen Caldwell, a will stendhaliana, ou seja, a energia ligada à vontade, tirada da palavra virtu, encontra seu sentido fluminense, ilustrando o encontro de duas personalidades que apresentam uma visão ampla e integradora da vida social, ressaltando-se,

\footnotetext{
${ }^{229}$ A mão e a luva, p. 269.

230 Idem, p. 265.

231 Idem.

232 Idem, p. 216.
} 
é preciso dizer, o fato de não haver real prejuízo a qualquer outra personagem, sobretudo os outros pretendentes que não conseguem seu intento em razão de sua perfeita inadequação à realidade do casamento como mola propulsora social.

A redenção de Helena

Assim como em A mão e a luva, a trama de Helena gira, na maioria dos capítulos, em torno do casamento. Se lá a questão principal se constrói em torno da busca do parceiro ideal, aqui ela parte do princípio da renúncia amorosa em favor da situação social. Daí a opção de conferir à personagem postura de tendência não idealizadora a esse respeito, como observamos na sua preferência de um destino seguro à possível realização amorosa:

“_ [...] é uma loteria; perco um bem certo por outro duvidoso. O jogador não faz cálculo diferente. Essa felicidade pode não vir; eu contento-me com o que me cabe agora. Mendonça ama-me deveras [...] O Padre Melchior abriu-me os olhos; aceito o destino que os dous me oferecem. Esta é a razão e a realidade; o mais é ilusão e fantasia."233

Apesar de tematizar um amor correspondido, percebemos, desde o início do texto, a impossibilidade de sua consumação. O empenho de Helena no casamento de Estácio com Eugênia e de seu próprio com Mendonça indica a escolha da protagonista pelo pragmatismo. Ao observarmos a passagem

${ }^{233}$ Helena, p. 344. 
acima, temos dificuldade em identificar a Helena completamente altruísta da análise de Schwarz. ${ }^{234} \mathrm{~A}$ objetividade revelada pelo discurso direto da personagem é patente. A profusão de termos de ordem prática -"loteria", "bem", "cálculo", "razão" e "realidade" - torna flagrante a condução do assunto como se fosse um contrato impessoal, bem como a recusa de qualquer decisão baseada no sentimento tido como "ilusão" ou "fantasia". Isso não quer dizer que a personagem seja predominantemente calculista, mas que tal faceta se confirma como um de seus vários elementos constitutivos, tornando-a mais complexa e temperando o holograma de feições cândidas.

A segurança demonstrada por Helena é um tanto contraditória, pois, diferentemente de Guiomar que se apoia na veracidade de sua origem e na legitimidade de sua ambição, está calcada em informação que, além de falsa, é mantida arbitrariamente em sigilo. Por isso, a situação na qual se encontra depende diretamente da ocultação dos fatos verídicos.

Portanto, há, em Helena, uma espécie de pecado original a ser expiado no decorrer da trama. Ora, é exatamente isso que ocorre. Não parece ser de todo errado ver no sofrimento da personagem, e na morte dele decorrente, a punição máxima da falha como contraponto que restaura o equilíbrio.

Enquanto em $A$ mão e a luva, a mudança de tom do texto ocorre com a definição do pretendente escolhido, em Helena, o caminho do enredo é desviado a partir do momento em que a verdadeira identidade da personagem

\footnotetext{
${ }^{234}$ SCHWARZ, Roberto. "Helena" in op. cit., p. 123 "Basta saber que Helena não tinha culpa no quiproquó, e foi tudo uma fatalidade do destino (grifo do autor)"; p. 129 "[...] Helena luta pela estima da família Vale, e não para passar de uma classe social a outra, e muito menos para ficar rica."
} 
vem à tona. Tal fato se desdobra em sequência significativa de cenas. Atentemos a elas:

"Durante o almoço, Estácio procurou observar Helena; trabalho ocioso, porque o rosto da moça, se alguma cousa traía nessa ocasião, eram as alegrias inefáveis da família." ${ }^{235}$

“_Que é? Repetiu esta [Helena] admirada.

A única resposta de Estácio foi estender o dedo sobre a misteriosa casa reproduzida na paisagem.[...] Súbito empalideceu; os lábios tremeram-lhe como a murmurar alguma cousa, mas a alma falou tão baixo que a palavra não chegou à boca." 236

As passagens acima, retiradas de capítulos subsequentes demonstram claramente o momento decisivo da virada da trama. A mudança do comportamento tranquilo de Helena para a completa desorientação ocorre pela revelação de Estácio, cabendo a ele, no texto, o esclarecimento dos eventos. 0 fato de tal revelação não se originar da confissão da heroína, mas do descobrimento do suposto irmão, agrava o ato de ocultação da verdade. Contudo, a partir dessa reviravolta, que tem a função de questionar a integridade da personagem, inicia-se a última etapa do romance, evidentemente de caráter redentor. Os momentos finais da heroína são narrados a partir de uma auréola de quase santidade, sugerindo a filiação do romance brasileiro a dados românticos de obras como A Dama das Camélias (1848) de Alexandre Dumas Filho, inclusive por se tratar, também, de um texto sobre a diferença de classes. No texto francês, no entanto, a doença (tuberculose) persegue a protagonista desde o início da narrativa. Sua possível

\footnotetext{
${ }^{235}$ Helena, p. 358.

${ }^{236}$ Idem, p. 359.
} 
inserção na sociedade sofre o combate incessante da moralidade média e, ficcionalmente, da insidiosa moléstia.

$\mathrm{Na}$ conjuntura romanesca composta por Machado, em que o respeito pela moral doméstica não deve ser abalado, a solução da morte de Helena parece ser a mais apropriada ao desfecho, visto que é, inclusive, chancelada por padre Melchior, o "pai espiritual" da família:

\begin{abstract}
"No meio daquela família, arriscada a dispersar-se, Melchior considerava a superioridade da morte sobre alguns lances terríveis da vida. Se o óbito de Helena tomara o lugar da carta, a dor seria violenta, mas o irremediável desfecho e o consolo da religião teriam contribuído para sarar a alma dos que ficassem e converter o desespero de alguns dias na saudade da vida inteira." ${ }^{237}$
\end{abstract}

A elevação moral e religiosa parece ser apenas a superfície da opinião do sacerdote. O sentido mais profundo e relevante da avaliação de Melchior está atrelado ao senso de conformidade social. A angústia de apenas "alguns dias" faz transparecer a preponderância da manutenção da coesão familiar sobre uma lástima passageira. Também inserida em tal conjuntura rígida, D. Úrsula adere sem hesitação à preocupação do padre com o "decoro da família" ${ }^{238}$ e o provável "escândalo" da situação, mencionado duas vezes no mesmo parágrafo. ${ }^{239}$

O sacrifício necessário de Helena como retratação à usurpação da identidade faz lembrar - em tom menor - o discurso de Julien Sorel ao júri,

\footnotetext{
${ }^{237}$ Helena, pp. 370, 371.

238 Idem, p. 371.

239 Idem, p. 381.
} 
sobretudo quando o observamos em paralelo com a explicação da motivação daquela:

\begin{abstract}
"Mon crime est atroce, et il fut prémédité. J'ai donc mérité la mort, messieurs les jurés. Mais quand je serais moins coupable, je vois des hommes qui, sans s'arrêter à ce que ma jeunesse peut mériter de pitié, voudront punir en moi et décourager à jamais cette classe de jeunes gens qui, nés dans une classe inférieure, et en quelque sorte opprimés par la pauvreté, ont le bonheur de se procurer une bonne éducation et l'audace de se mêler à ce que l'orgueil des gens riches appelle la société.

Voilà mon crime, messieurs, et il sera puni avec d'autant plus de sévérité, que dans le fait je ne suis point jugé par mes pairs. Je ne vois point sur les bancs des jurés quelque paysan enrichi, mais uniquement de bourgeois indignés..."240
\end{abstract}

"A sagacidade natural do espírito cedo lhe fizera ver que a posição de sua mãe não era a mesma das outras mães; essa descoberta, porém, não teve outra virtude mais que comunicar ao amor de filha uma intensidade e energia capazes de afrontar os mais fortes obstáculos, como se ela quisesse reunir em si toda a soma de afetos e respeitos que a sociedade afiança às situações regulares." 241

A discussão dos dois textos se centra na questão da legitimidade ou não das personagens em ocupar uma posição conquistada, adquirida a duras penas. Machado opta pela completude de tal empreitada em $A$ mão e a luva e Quincas Borba; em Helena, ao construir um enredo em que o movimento central do texto consiste no dilema da personagem em assumir arbitrariamente um título/parentesco que não lhe pertence, inserindo-o, portanto, no tema do "engano", o autor prefere o caminho da retratação e da elevação. Para tanto, o

240 STENDHAL. Le rouge et le noir em seu Oeuvres romanesques complètes. Paris: Bibliothèque de La Pléiade, Éditions Gallimard, 2005, tome I, p. 782.

${ }^{241}$ Helena, p. 384. 
desfecho da morte parece ser a alternativa cuja natureza inquestionável se adequa ao resgate da integridade por se tratar do mais extremo sacrifício.

A tentativa de pertencimento a um estrato mais elevado por parte de Julien e Helena pode ser percebida como legítima, mas a recusa final de integração ao novo meio, além de redimi-los, expõe a grande fragilidade dos desfavorecidos perante a rigidez das "situações regulares" socialmente estabelecidas. Nesse sentido, a conclusão do padre Melchior a respeito da quase "preferível" morte de Helena, como se ele cumprisse o papel de portavoz da moral e dos bons costumes vigentes, assemelha-se à postura condenatória dos jurados na audiência de Julien Sorel.

Sofia em Botafogo: a inversão do espaço

"E Sofia? Interroga paciente a leitora, tal qual Orgon: Et Tartufe? Ai, amiga minha, a resposta é naturalmente a mesma, - também ela comia bem, dormia largo e fofo, - coisas que, aliás, não impedem que uma pessoa ame, quando quer amar.[...]

Repito, comia bem, dormia largo e fofo. Chegara ao fim da comissão das Alagoas, com elogios da imprensa; a Atalaia chamou-lhe "o anjo da consolação". E não se pense que este a alegrou, posto a lisonjeasse; ao contrário, resumindo em Sofia toda a ação da caridade, podia mortificar as novas amigas, e fazer-lhe perder em um dia o trabalho de longos meses.". 242

"Mas - oh lance da fortuna! oh equidade da natureza! - os desperdícios do nosso amigo, se não tinham remédio, tinham compensação. Já o tempo não passava por ele como por um

${ }^{242}$ Quincas Borba, pp. 760, 761. 
vadio sem ideias. Rubião, à falta delas, tinha agora a imaginação." 243

Observadas em paralelo, as passagens acima apontam para o que será o desfecho do romance. Apesar de ser evidente a intercalação de cenas do declínio de Rubião e da ascensão de Sofia e Cristiano, com o fim de demonstrar a degradação daquele como necessária à subida destes, interessa analisar mais detidamente o modo pelo qual a construção textual o faz.

O "comia bem, dormia largo e fofo" em contraposição aos "desperdícios" de Rubião revela o pragmatismo do casal e a vida ilusória do herdeiro de Quincas Borba. No mesmo sentido, o comportamento hipócrita de Sofia ressaltado pela comparação com Tartufo $^{244}$-, disfarçado pelo véu da filantropia, nos remete à cena em que Rubião salva o menino Deolindo. A ação de socorrer a criança do possível atropelamento decorre do reflexo quase impensado do professor de Barbacena, o que a torna honesta e genuína, embora não tenha nada de heroica. Ao contrário, o grande empenho da esposa de Palha em ajudar os desabrigados das Alagoas não se baseia, em nenhum instante, no altruísmo.

Desse modo, as reações de ambas as personagens à repercussão pública de tais fatos são significativas. No primeiro caso, o enaltecimento exacerbado de Camacho, outro parasita nas costas de Rubião, tem função de agravar as alucinações de grandeza deste, de modo que a notícia quase fictícia vá ao encontro dos anseios do protagonista. Já o

\footnotetext{
${ }^{243}$ Quincas Borba, p. 760.

${ }^{244}$ A esse respeito ver a análise de Gilberto Pinheiro Passos em seu O Napoleão de Botafogo. Presença Francesa em Quincas Borba de Machado de Assis, pp. 54, 55.
} 
destaque do esforço de Sofia na comissão, por se tratar de um trabalho realizado não obstante suas intenções verdadeiras, deveria ser efusivamente celebrado por ela, mas não o é. Diferentemente do suposto amigo da família desprovido de ideias, Sofia as tem e elas são muitas. Recém-chegada em um núcleo mais fechado e exclusivo, qualquer pequeno obstáculo poderia ser um retrocesso. Daí, a opção de ascender gradativamente, mantendo o cuidado de não se sobressair demais até que esteja em situação mais segura.

Seguindo o mesmo raciocínio, a representação da subida do casal Palha e do declínio de Rubião também se faz pelo espaço. A última residência da família, o palacete de Botafogo, remonta ao início da narrativa, momento em que Rubião ocupa a casa herdada no mesmo bairro:

"Seguiu-se a mudança para a casa de Botafogo, uma das herdadas; foi preciso alfaiá-la, e ainda aqui o amigo Palha prestou grandes serviços ao Rubião, guiando-o com o gosto, com a notícia, acompanhando-o às lojas e leilões. Às vezes, como já sabemos, iam os três; porque há cousas, dizia graciosamente Sofia, que só uma senhora escolhe bem." ${ }^{245}$

Nesse trecho, encontramos o gérmen do enredo. Ainda em Santa Teresa, a ajuda de viés interesseiro na organização da morada do recente amigo, aliando a praticidade do marido e os gracejos indispensáveis da mulher, cumpre papel de ensaio para a dupla, cujo palco principal da coreografia já ensaiada será a mansão a ser construída futuramente na mesma vizinhança. Do mesmo modo, no período em que a condição mental e financeira de Rubião se agrava, os Palha, já há algum tempo devidamente acomodados no

\footnotetext{
${ }^{245}$ Quincas Borba, p. 661.
} 
Flamengo, transferem Rubião para o casebre de quarto e sala da Rua do Príncipe, como se fosse preciso desocupar o bairro de Botafogo para preparar a instalação definitiva do casal no mesmo lugar. Por fim, a internação do provinciano de Barbacena, já vencido pela loucura, na casa de saúde, coincide com a finalização da construção dos salões triunfantes de Sofia naquele mesmo bairro onde tudo começa e termina:

"Rubião foi recolhido a uma casa de saúde. Palha esquecera a obrigação que Sofia Ihe impôs, e Sofia não se lembrou mais da promessa feita à rio-grandense. Cuidavam ambos de outra casa, um palacete em Botafogo, cuja reconstrução estava prestes a acabar [...]"246

"Em outubro, Sofia inaugurou os seus salões de Botafogo, com um baile, que foi o mais célebre do tempo. Estava deslumbrante. Ostentava, sem orgulho, todos os seus braços e espáduas. Ricas joias; o colar ainda era um dos primeiros presentes do Rubião, tão certo é que, neste gênero de atavios, as modas conservam-se mais." ${ }^{247}$

Chegou, enfim, a hora e a vez do espetáculo final de Cristiano e Sofia. Agora sim, sem motivos para evitar o comedimento, Sofia exibe os salões e o colar. A joia representa exatamente a função do professor na vida do casal, ou seja, a tensão estabelecida pelo texto entre a necessidade de sua presença e a impossibilidade de sua permanência. Daí, a oposição sequencial dos espaços: Santa Teresa / residência de Rubião em Botafogo; Flamengo / casebre da Rua do Príncipe; palacete de Botafogo / casa de saúde. O movimento circular da narrativa, tendo como referência Botafogo, chama a atenção para a permanência e constância do recurso material - joia/dinheiro -

\footnotetext{
${ }^{246}$ Quincas Borba, p. 799.

247 Idem, p. 803.
} 
e do prestígio social em função deste, ao mesmo tempo em que explicita a transitoriedade das figuras, exemplificada pela ausência de Rubião no baile final.

Fica demonstrada, dessa maneira, a eficiência da estratégia calculada e pacientemente executada pela mesma Sofia: a que envia morangos e bilhetes com o aval do marido e a que se mantém impassível na última visita ao doente deplorável, sem que esta lhe cause "nenhuma recordação pessoal"248 ou "comoção particular e profunda"249, tornando o carreirismo ainda mais insidioso, porque habilmente orquestrado por um narrador em terceira pessoa que pode se locomover pelos espaços, pontuando-os a partir do tema do arrivismo.

Sofia ascende socialmente como Guiomar, mas esta é pudica e comedida. A mulher de Palha não, portanto está muito mais próxima, aos olhos de Rubião, da primeira relação do professor provinciano com o Rio de Janeiro das "moças bonitas, 'vestidas à francesa”". ${ }^{250}$ Dessa maneira, o romance já prepara o leitor para a transposição espacial delirante do protagonista, pois ele já começa a imaginar sua França de "opereta".

A figura de Sofia não pode ser dissociada também da ideia de seu corpo, pois ela se serve dele para ocupar seu verdadeiro lugar social, o de destaque. Possuidora de físico privilegiado - tanto na visão do narrador quanto nas de Cristiano e Rubião -, sua ascensão vai-se pontuando pelo desnudar do corpo, e, ao mesmo tempo, pelos enfeites (joias) que ele recebe. Quanto mais

\footnotetext{
${ }^{248}$ Quincas Borba, p. 801.

${ }^{249}$ Idem.

${ }^{250}$ Idem, p. 655.
} 
muda de casa, mais "nua" e enfeitada fica. Por constituir uma das miragens na vida do professor, a fantasia dessa mulher propicia, em parte, os sucessos do casal. $^{251}$

Nesse ponto, Machado está mais próximo de Proust, que trabalha amplamente o elemento de sedução em Odette. Se, nas outras duas obras, a sensualidade não se fazia quase nunca presente, ela constitui, em Quincas Borba, um papel fundamental. Diferentemente dos perfis recatados de Guiomar e Helena, o escritor constrói uma personagem vinculada ao uso do corpo como elemento indispensável à elevação social.

Odette e Madame Verdurin: o reencontro no grand monde

Coincidindo com a estrutura circular da obra, cujo fim retoma o início, os destinos de Odette e Madame Verdurin convergem para o mesmo ponto. Como já foi dito, ambas percorrem todos os volumes da Recherche, de modo que funcionam como referência da passagem do tempo e das mudanças sociais ali representadas. Mesmo durante o longo intervalo do afastamento entre elas,

\footnotetext{
${ }^{251}$ MURICY, Kátia, op. cit., p. 82: "É o casamento e são as esposas e filhas, enquanto mercadorias sensuais na troca de favores pecuniários e obtenção de prestígio social, o elo mais forte da ordem burguesa. As mulheres são peça privilegiada na troca dos favores, em virtude de sua tendência à adulação, característica cuja 'naturalidade' é obtida por sua ligação com o afeto: 'Observei que a adulação das mulheres não é a mesma coisa que a dos homens. Esta orça pela servilidade; a outra confunde-se com a afeição' [citação de Memórias Póstumas de Brás Cubas]".
} 
exigido por Swann, o narrador observa suas movimentações em paralelo mostrando como a situação de uma nunca deixa de estar nas considerações da outra. Por meios indiretos - os casamentos de Gilberte e Madame Verdurin com dois Guermantes -, veremos, não por acaso, a conquista do faubourg Saint-Germain pela cocotte e pela Patronne no desfecho da obra.

Vemos, no decorrer dos sete romances, a preparação constante e gradativa para a consolidação final através dos vários degraus galgados pelas personagens. Há, contudo, dentre as etapas, situações decisivas que funcionam como ponto de virada, de maneira a confirmar o novo status adquirido. A presença de Odette nos ensaios da peça de Bergotte e a posição pró Dreyfus bem como a promoção dos balés russos por Madame Verdurin são alguns exemplos. Vamos a eles:

"Pour Odette, au commencement, quelques hommes de la plus haute société, curieux de connaître Bergotte, avaient été dîner chez elle dans l'intimité. Elle avait eu le tact récemment acquis de n'en pas faire étalage; [...] Ce changement de la situation d'Odette s'accomplissait de sa part avec une discrétion qui le rendait plus sûr et plus rapide, mais ne laissait nullement soupçonner du public enclin à s'en remettre aux chroniques du Gaulois des progrès ou la décadence d'un salon, de sorte qu'un jour, à une répétition générale d'une pièce de Bergotte donnée dans une salle des plus élégantes au bénéfice d'une oeuvre de charité, ce fut un vrai coup de théâtre quando on vit dans la loge de face, qui était celle de l'auteur, venir s'asseoir à côté de Mme Swann, Mme de Marsantes et celle qui par l'effacement progressif de la duchesse de Guermantes (rassasiée d'honneurs, et s'annihilant par moindre effort), était en train de devenir la lionne, la reine du temps, la comtesse Molé."252

252 Sodome et Gomorrhe, pp. 142, 143. 
De forma similar a Madame Verdurin, mas por meio de diferente estratégia, Madame Swann constrói também um salão político e artístico. Enquanto a primeira se arrisca na defesa feroz de Dreyfus e se dedica à promoção da pintura, da música e da dança, a segunda constitui um ambiente nacionalista, apesar do marido judeu, e concentra os esforços no reconhecimento da produção literária nutrida em sua casa, mais especificamente a obra de Bergotte. Como já dissemos, o escritor e a mulher de Swann evoluem simultaneamente, de modo que a passagem da obscuridade à glória do primeiro, comentada pelo narrador ${ }^{253}$, ocorre também, em certa medida, com a segunda.

A discrição enfatizada no texto revela a sabedoria de Odette no modo de conduzir sua escalada. Assim como em Quincas Borba, as situações frágeis e ainda instáveis não devem ser alardeadas até que suas estruturas estejam mais firmes. Sofia e Odette aparecem publicamente em posição de destaque o baile final em Botafogo e o ensaio da peça de teatro - apenas quando não há muito espaço para objeções, visto que, em ambos os casos, elas estão protegidas por feitos benemerentes - a comissão das Alagoas e o espetáculo beneficente - e apoiadas por figuras de conhecida envergadura social - Dona Fernanda e as aristocratas Marsantes e Molé. A enorme distância que separava a antiga Madame de Crécy do primeiro salão Verdurin, onde tudo dava impressão de pequenez, como assinalamos anteriormente, - demimondaine ${ }^{254}$, petit nom ${ }^{255}$ - desaparece nesse instante em que ela se

\footnotetext{
253 Sodome et Gomorrhe, p. 141.

${ }^{254}$ Du côté de chez Swann, p. 185.

255 Idem, p. 186.
} 
encontra no meio do que há de mais superlativo - la plus haute société, une salle des plus élégantes, la lionne, la reine du temps.

Note-se que o narrador utiliza o pronome on para retratar uma visão plural pública do fenômeno descrito. Não se trata, apenas, de algo particular, mas (e não por acaso num teatro) da consolidação notória de uma integração de classes.

Outro detalhe significativo é a presença específica de Madame de Marsantes, mãe de Saint-Loup e irmã do duque de Guermantes. Ao seguirmos a sugestão de Álvaro Lins, de voltar ao início da obra depois da leitura do último capítulo ${ }^{256}$, notamos com mais facilidade algumas antecipações lançadas pelo narrador. Ora, esse é justamente o momento de guinada de Odette, pois, estando ao lado de tal dama, prefigura o que virá a seguir, o casamento de Gilberte com Saint-Loup e seu papel derradeiro como amante do duque.

Também, a observação feita a respeito da perda de prestígio da duquesa de Guermantes é um tanto irônica, pois remete a um só tempo ao passado e ao futuro do enredo. Se nos primeiros tempos Madame Swann e a filha não poderiam nem ser recebidas, elas terminam por ocupar simbolicamente todos os domínios de Oriane de Guermantes, invertendo completamente o esquema anterior. Gilberte não só fará parte da família, como

\footnotetext{
${ }^{256}$ LINS, Álvaro. Da técnica do romance em Marcel Proust. Rio de Janeiro: edição reservada feita pelo autor como tese apresentada a concurso para uma das cátedras de Literatura do Colégio Pedro II, 1950, p. 5. "O que importa dizer que esta obra exige duas leituras para ter-se dela uma compreensão integral. Depois da última página, a primeira; de novo a obra toda, como a segunda volta num círculo; e só então ela será sentida e compreendida por inteiro, assim como que fechada sobre si mesma [...]"
} 
também assumirá o mesmo título de duquesa de Guermantes; Odette, por sua vez, terá a dedicação completa de Basin de Guermantes, atenção nunca demonstrada à sua mulher legítima. Tais fatos rebaixam social e moralmente a antes gloriosa duquesa. Os espaços do sentimento e da sociedade são limitados não podendo abrigar todos os candidatos ao mesmo tempo. Não é possível que o casal Palha e Rubião, assim como a duquesa de Guermantes e Odette ocupem simultaneamente os mesmos lugares. Para que uns subam, outros devem descer.

No caso de Madame Verdurin, sabemos que o advento da guerra será decisivo. No entanto, a emergência por si só do evento não seria o bastante se ela não tivesse se preparado longamente para aproveitar cada oportunidade surgida: Chez Mme Verdurin la troupe était parfaite, entraînée, le répertoire de premier ordre, il ne manquait que le public. ${ }^{257} \mathrm{O}$ narrador mostra que as etapas intermediárias são tão ou mais importantes que o triunfo final, pois insiste em mostrar cada fase presente como consequência direta ou indireta das anteriores.

Assim, como para Odette o lance que a alçaria ao primeiro escalão de Paris foi a cena do teatro, o fator responsável por alavancar Madame Verdurin também viria do mundo das artes ${ }^{258}$ com os balés russos:

"[...] nous verrons, à toutes les représentations des «Russes», siéger comme une véritable fée, ignorée jusqu'à ce

\footnotetext{
${ }^{257}$ La Prisonnière, p. 741.

258 Segundo Bidou-Zachariasen, a opção de Madame Verdurin de se enveredar para o universo artístico ocorre pelo fato de ele ser um campo pouco institucionalizado; poderíamos aqui inferir o mesmo raciocínio também para o caso de Odette, op. cit., p. 91.
} 
jour de l'aristocratie, Mme Verdurin, nous pouvons répondre aux gens du monde qui croiront aisément Mme Verdurin fraîchement débarquée avec la troupe de Diaghilev, que cette dame avait déjà existé dans des temps différents, et passé par divers avatars dont celui-là ne différait qu'en ce qu'il était le premier qui amenait enfin, désormais assuré, et en marche d'un pas de plus en plus rapide, le succès si longtemps et si vainement attendu par la Patronne." 259

O momento de transição do quase anonimato ao reconhecimento é composto por dois olhares: nous (narrador e leitor) e a aristocracia, de maneira que o primeiro conhece todo o longo percurso de Madame Verdurin e o segundo se vê surpreendido por sua figura inovadora ao promover espetáculo tão arrojado quanto a trupe russa. Começamos a perceber, a partir de Sodome et Gomorrhe, a aceleração do tempo no que concerne ambas as personagens, Odette e Madame Verdurin. As extensas reflexões acerca do primeiro salão da Rua Montalivet, das recepções de Madame Swann e da Raspelière parecem traduzir a grande relevância da preparação nessas trajetórias, cujo resultado chegaria, na cronologia da obra, apenas ao final de três décadas. ${ }^{260}$

Do mesmo modo, a sensação de uma quase lentidão na descrição dos eventos dos primeiros volumes citados acima em oposição à rapidez das duas passagens transcritas aqui - reforçada pelas expressões plus rapide em uma e de plus en plus rapide em outra - poderia indicar o desaparecimento da considerável estabilidade e imobilidade sociais experimentadas pela França,

\footnotetext{
${ }^{259}$ Sodome et Gomorrhe, pp. 140, 141.

${ }^{260}$ A Recherche seria ambientada entre 1879 e 1919. O balé russo de Diaghlev se apresentou em Paris em 1909.
} 
apesar dos cem anos passados desde a Revolução. ${ }^{261} \mathrm{~A}$ verdadeira transformação estrutural nos grupos apontada pelo romance será consolidada somente com a eclosão da guerra, pois cenas como a soirée do duque e da duquesa de Guermantes, apesar de se situarem na virada do século, se adequam mais ao Antigo Regime do que à modernidade.

Se, na primeira parte da narrativa, constatamos um mundo cingido em partes muito bem delimitadas e codificadas como universos quase independentes, o desfecho da trama converge para um espaço único cuja unidade está paradoxalmente no amálgama dos núcleos apresentados nos volumes iniciais: os salões dos Verdurin, dos duques de Guermantes, dos príncipes de Guermantes e dos Swann. Todos estão representados na matinée final da nova princesa de Guermantes assim resumida:

"Et ainsi le salon de la princesse de Guermantes était illuminé, oublieux et fleuri, comme un paisible cimetière. Le temps n'y avait pas seulement défait d'anciennes créatures, il y avait rendu possibles, il y avait créé des associations nouvelles." 262

Estão contidos nessa síntese alguns dos principais interesses da obra: a passagem do tempo e a transformação social. Não por acaso, o romance termina com uma recepção à qual estão presentes Madame Verdurin

\footnotetext{
${ }^{261}$ A esse respeito Julia Kristeva observa: "On croit facilement que la Révolution bourgeoise française fut la plus radicale du monde. N'a-t-on pas décapité le roi, la reine, la noblesse, les cathédrales? On oublie que les bourgeois, obnubliés par les moeurs et les manières de l'aristocratie, ne se lassent pas de mimer ses hiérarchies, d'imiter ses partages, de singer ses clotûres. Tout ce qui fait de la société française moderne un des univers les plus classiques qui soient, véritable puzzle de castes infranchissables.", op. cit., p. 80.

${ }^{262}$ Le Temps retrouvé, p. 527.
} 
e Odette, de forma a ressaltar a perenidade delas no decorrer de todas as fases da trama.

Não surpreende que Odette, agora como Madame de Forcheville, termine por retornar às origens de cocotte como última amante do envelhecido duque de Guermantes. O texto nos antecipa a informação, que virá mais adiante, ao lançar mão daquele mesmo recurso de associação entre a personagem e as cores destacado anteriormente. Como Madame Swann, Odette é mostrada toda imersa nos tons claros, transparentes, como forma de diferençá-la da femme entretenue de "Un amour de Swann". Aqui, o retorno dos tons avermelhados consolida a essência de mulher sensual que pauta sua movimentação e seu desenvolvimento no romance, deixando para trás inclusive o nome, substituído por Forcheville:

"Pour Mme de Forcheville au contraire, c'était si miraculeux, qu'on ne pouvait même pas dire qu'elle avait rajeuni, mais plutôt qu'avec ses carmins, toutes ses rousseurs, elle avait refleuri." 263

Tudo, nessa passagem, remete aos primeiros tempos do pequeno salão Verdurin, justificando a volta de Odette aos domínios da antiga protetora. 0 nome do último marido - Forcheville - alude não somente ao passado e ao antigo relacionamento, mas também aos hábitos de cocotte, supostamente deixados de lado na fase dos tons alvos como esposa do diletante. Cumprindo a mesma função, os matizes quentes - carmins, rousseurs - reforçam o

\footnotetext{
${ }^{263}$ Le Temps retrouvé, p. 528.
} 
resgate da vida anterior confirmado pela conexão com o duque de Guermantes.

Quanto a Madame Verdurin, sua habilidade sistemática em tirar vantagem de cada situação nova a encaminha para o triunfo:

"C'est ainsi que, à chaque crise politique, à chaque rénovation artistique, Mme Verdurin avait arraché petit à petit, comme l'oiseau fait son nid, les bribes successives, provisoirement inutilisables, de ce qui serait un jour son salon." 264

As manifestações artísticas e políticas mais relevantes da trama se promovem sob sua tutela: o caso Dreyfus, a pintura de Elstir, a sonata de Vinteuil e os balés russos. Esse encadeamento de eventos culmina na jogada final, propiciada pela guerra, com o casamento entre ela e o príncipe de Guermantes, "ruiné par la défaite allemande"265.

"En effet, Mme Verdurin, peu après la mort de son mari, avait épousé le vieux duc de Duras, ruiné, qui l'avait faite cousine du prince de Guermantes, et était mort après deux ans de mariage. II avait été pour Mme Verdurin une transition fort utile, et maintenant celle-ci par un troisième mariage était princesse de Guermantes et avait dans le faubourg SaintGermain une grand situation qui eût fort étonné à Combray $[\ldots]^{\prime 266}$

Madame Verdurin encarna, ainda mais que Odette, o senso de oportunismo na nova ordem social. Dando um passo de cada vez, ela se serve paulatinamente de todas as ocasiões para tirar algum proveito delas. Ancorada

\footnotetext{
${ }^{264}$ La Prisonnière, p. 741.

${ }^{265}$ Le Temps retrouvé, p. 533.

${ }^{266}$ Idem.
} 
por sua fortuna, vê-se livre, com a morte do primeiro marido, para adentrar legitimamente o seio da elite parisiense. O texto demonstra como tal conjuntura - a integração entre Verdurin e Guermantes - se torna possível através da coexistência de pelo menos dois fatores simultâneos e interdependentes: a astúcia da personagem - il avait été pour Mme Verdurin une transition fort utile - e a transformação daquele meio, com ênfase na ruína dos dois maridos aristocratas.

A oposição que se faz entre a movimentação constante de Odette e Madame Verdurin e a estabilidade da família do narrador, em Combray, nos remete novamente a "Un amour de Swann", pois, ali, estão os primeiros comentários de desaprovação acerca de ambas bem como a aliança degradante de Swann e a vulgaridade do casal Verdurin. A surpresa para a pequena cidade de província é pertinente, pois o núcleo familiar do narrador é a única estrutura que não sofre, no decorrer do enredo, nenhuma consequência das grandes reviravoltas representadas.

Não obstante o quase congelamento do grupo de Combray, os caminhos de Swann e de Guermantes se encontram personificados em Mlle de SaintLoup, fruto da improvável conjunção entre Odette e a família Guermantes:

"Ma présentation à Mlle de Saint-Loup allait avoir lieu chez Mme Verdurin [...] Et pour mieux fondre tous mes passés, Mme Verdurin tout comme Gilberte avait épousé un Guermantes."267

A presença de Mlle de Saint-Loup nessa recepção sintetiza as trajetórias ascensionais de Odette e Madame Verdurin. A superação das

${ }^{267}$ Le Temps retrouvé, p. 608. 
barreiras antes intransponíveis entre os dois universos culmina na integração completa dos representantes de meios díspares, sendo a filha de Gilberte, descendente de Swann e dos Guermantes, o exemplo mais simbólico da conquista de Odette. No mesmo sentido, Madame Verdurin alcança o que sempre quis como anfitriã ao reunir no mesmo espaço as figuras mais proeminentes da burguesia e da aristocracia, tendo ela mesmo se transformado em uma síntese das camadas mais altas da sociedade francesa.

Tais consolidações se constroem com a soma dos vários ângulos vistos, no tempo e no espaço, por um narrador que, de certo modo, não pertence completamente a nenhum dos núcleos integrantes da narrativa. Só mesmo uma voz que não entra totalmente no jogo social, mas o observa, pode dar conta da realidade multifacetada do arrivismo. Desse modo, a matinée da princesa de Guermantes funciona como epítome das diversas situações sociais descritas e vividas ao longo de todo o romance pelo narrador.

Interessante notarmos ainda a significativa sucessão de declínios de muitas personagens masculinas. Todas são rebaixadas de alguma forma. As mortes de Swann, Saint-Loup e Monsieur Verdurin, a velhice do príncipe de Guermantes, a demência de Charlus e a doença do próprio narrador revelam inegável decadência física. Da mesma maneira, a ruína do príncipe e a derrocada do barão indicam suas decaídas econômica e social, respectivamente. Em contrapartida, a ascensão das arrivistas - Odette, Verdurin e Gilberte - é vertiginosa e proporcional à queda masculina. As figuras femininas são as principais responsáveis pelas profundas transformações vistas no romance, pois tais mudanças parecem decorrer - 
paralelamente às possibilidades surgidas no contexto histórico-social - das variadas movimentações sociais por elas promovidas. 


\section{Capítulo V}

\section{Arrivismo feminino como articulador narrativo}

Apagar o passado

O empenho em desvencilhar-se do passado constitui um dos elementos comuns a todas as personagens analisadas. Não vemos, em Machado ou Proust, a valorização, pelas figuras arrivistas, do percurso ascensional em sua totalidade. Para a vivência de cada nova etapa, a anterior deve ser deixada para trás, pois a identificação dos novos membros com o grupo de chegada se revela como passo importante para a integração social.

Em A mão e a luva e Helena, obras ancoradas, em parte, no idealismo romântico, somente heroínas possuidoras de caráter superior podem ser agregadas ao convívio da família rica e respeitada. Tal mudança ocorre por golpes do destino, a exemplo da morte da filha da baronesa e do conselheiro, sem os quais a incorporação da parente pobre como membro legítimo da família seria mais improvável e menos verossímil. Desse modo, cabe a Guiomar e a Helena servir-se de toda sua habilidade para adaptar-se ao novo meio, não expondo a ele as experiências passadas, mas apagando-as para ressaltar apenas os hábitos e gestos condizentes com os costumes do grupo atual. 
Os enredos de A mão e a luva e Helena se passam em 1853 e 1859, respectivamente, em um momento estável do Segundo Reinado, cujos estratos sociais estão bem estabelecidos e aparentemente protegidos. Por isso, a separação dos meios é bastante rígida e as protagonistas só podem fazer parte da elite porque se identificam perfeitamente com ela. No caso de Guiomar, o descolamento com o passado é completo, segundo a lição empreendida pelo narrador, sempre atento a pontuar o caminho da personagem:

"Ela vivia do presente e do futuro e, - tamanho era o seu futuro, quero dizer as ambições que Iho enchiam, tamanho, que bastava a ocupar-lhe o pensamento, ainda que 0 presente nada mais the dera. Do passado nada queria saber; provavelmente havia-o esquecido." 268

Em $A$ mão e a luva, a ruptura com os antecedentes se mostra completa e anunciada desde as primeiras cenas. Os sofrimentos relatados no capítulo "Meninice", face ao luxo inacessível das moças ricas, separam Guiomar de sua origem, ou seja, do passado infeliz já esquecido com o qual não tem vínculo afetivo. O fato de a ascensão da personagem ser possibilitada por duas mortes, de sua mãe e da filha da madrinha, preserva certa correção de conduta da protagonista, pois, além de desvinculá-la da família humilde sem precisar abandoná-la, restabelece a relação filial ao colocá-la no lugar de Henriqueta, de forma a atenuar o cálculo com a adição do sentimento verdadeiro.

Em Helena, temos um caso mais ambíguo e complexo. A personagem se movimenta em dois espaços inconciliáveis, a casa do conselheiro e a cabana do pai, mas pende indubitavelmente para o primeiro. Isso não ocorre ${ }^{268}$ A mão e a luva, p. 229. 
somente por uma questão de escolha, apesar de haver opção de se passar por irmã legítima de Estácio. Toda a composição dos caracteres de Helena - "um acordo de virtudes domésticas e maneiras elegantes" 269 aliado à "flexibilidade do espírito" 270 - a aproxima mais da família abastada que dos modos simples de Salvador.

Contudo, apesar de igualar-se a Guiomar na notável arte de adaptação, Helena enquadra-se mais na categoria de personagens de exceção ${ }^{271}$, afastando-se, ao final, da posição confortável possibilitada pelo acatamento das convenções sociais. Helena desprende-se dos sucessos conquistados em seu meio, entregando-se à morte por ser a única maneira de restabelecer a dignidade esfumada pela manutenção da falsa identidade, o que chega a aureolar a personagem, misto de humanidade e santidade.

Se, em A mão e a luva, a dupla morte confere legitimidade à situação de Guiomar, em Helena a permanência do pai verdadeiro funciona como o fio invisível que a conecta de modo inegável à origem humilde e à fraude social.

De todo modo, em termos de composição, o passado da personagem permanece apagado, sempre no nível subterrâneo da trama. Todos os gestos da protagonista são vistos no seio do novo círculo como membro daquela família. Apesar das frequentes visitas a Salvador, não há uma única cena de

\footnotetext{
${ }^{269}$ Helena, p. 286.

270 Idem.

${ }^{271}$ Concordamos aqui com Alfredo Bosi a respeito do desfecho de Helena: "Helena desmente as expectativas "normais", ou seja, as expectativas do que constituiria a média dos comportamentos esperáveis no seu contexto. [...] Machado atribui a Helena um ideal de nobreza íntima, atípico, logo imprevisível, se considerados seu "berço" e a situação equívoca em que entrou para a família do Conselheiro Vale" em O enigma do olhar. São Paulo, Editora Ática, 1999, p. 47.
} 
tais encontros, apenas os relatos das viagens a cavalo e das cartas. O narrador não nos permite participar das interações entre pai e filha, ou seja, do ambiente familiar real correspondente às raízes de Helena. O texto se concentra sobretudo no presente e na possibilidade de futuro; o passado vem à tona somente no desfecho com o desvelamento da filiação verdadeira e a morte como consequência. Assim, observamos em $A$ mão e a luva e Helena a agregação de figuras que sabem harmonizar-se com os costumes e preceitos de famílias bastante fechadas em si mesmas, representantes de uma sociedade rígida e estável. A ascensão, em tais contextos, é incomum. Apesar de o talento das personagens ser preponderante, o percurso se inicia a partir de um golpe do destino, sem o qual tal ensejo seria improvável.

Em Quincas Borba, malgrado a pequena diferença temporal de menos de uma década do período ficcionalizado em Helena, o cenário já é outro. Localizado entre 1867 e 1871, o enredo revela uma trama mais complexa, com tipos mais variados de personagens e, entre elas, conexões de múltiplas naturezas, decorrentes de uma maior fluidez social. ${ }^{272}$ Ao invés de ascensão decorrente de um acaso ou de um lance da fortuna, vemos a astúcia e os procederes eticamente contestáveis do casal finalmente vitorioso. Aqui, observamos seu grande senso de oportunismo, já sinalizado com a menção às especulações financeiras de Palha, anteriores ao advento de Rubião. O relacionamento travado com o professor servirá como catalisador da execução de um projeto que sempre existiu, a exemplo da cena do trem de Vassouras para a Capital.

\footnotetext{
${ }^{272}$ Acompanhamos aqui o estudo de contextualização histórica de Quincas Borba feito por John Gledson em Machado de Assis: Ficção e História. São Paulo, Paz e Terra, 2003, pp. 73133.
} 
Não menos importante que as ambições pecuniárias é a vontade de lustre social perseguido pelo casal. Enquanto em A mão e a luva e em Helena, as protagonistas se elevam ao serem recebidas por núcleos já estabelecidos, Sofia e Cristiano, ao ascenderem como um par (ou seja, com motivações funcionando em uníssono), têm de criar um novo círculo de convivas para se tornarem parte de outro nível social. Guiomar e Helena, transferidas diretamente do internato para as casas das famílias, não precisam abandonar ninguém, pois não fazem parte de nenhum grupo. Todos os esforços, nesses casos, serão voltados à conquista da empatia daqueles que as recebem.

Já com o casal Palha a situação é diferente. Haverá dois movimentos simultâneos na trama: a inserção no novo meio e a supressão do passado. Para que o primeiro tenha êxito, o segundo será colocado em prática. Como vimos, a eliminação da vida anterior da dupla ocorrerá por meio das constantes substituições dos espaços e dos convivas. A casa de Santa Teresa, o major Siqueira, sua filha e até mesmo Rubião desaparecem dos domínios de Cristiano e Sofia para darem lugar ao palacete de Botafogo, a D. Fernanda, Teófilo e o diretor de banco.

Em paralelo vai-se depauperando a fortuna - e com ela - a saúde mental de Rubião, personagem principal da obra e fruto de preocupação minuciosa do narrador em relatar sua integração social. A ascensão, portanto, é mais dramática, não só por todos os lances revelados ao leitor, mas, sobretudo, pela cena final da morte do provinciano que ocorre concomitantemente ao sucesso alheio. 
Na Recherche, a elite está organizada em torno de títulos, de maneira que as trajetórias de Odette e Madame Verdurin são pautadas outrossim pelas mudanças de nome.

Ao usar a maternidade e o casamento com Swann como ferramenta de ascensão, Odette pode abandonar o nome "de Crécy", pelo qual era conhecida na condição de cocotte, para assumir a posição de Madame Swann e desfrutar os primeiros sucessos sociais de seu salão literário. Com a morte do marido, há a segunda troca de sobrenome, não menos significativa que a primeira. Passando a chamar-se Madame de Forcheville, transfere o título a Gilberte para que esta possa ser finalmente recebida pelos Guermantes. Dessa forma, tanto os antecedentes da mãe quanto os da filha são velados, em consonância com o desaparecimento da figura paternal. Ao desvincularem-se de Swann, a integração de ambas ao mais alto patamar da hierarquia aristocrática tem início. Gilberte completa o percurso ascensional traçado por Odette ao obter o título de Madame de Saint-Loup, consolidando o prestígio social longamente cultivado.

Algo semelhante ocorre com Madame Verdurin. O segundo casamento com um nobre falido, o duque de Duras, serve para apagar o primeiro nome de família obscura e também como degrau necessário para alcançar o título de princesa de Guermantes, fazendo com que a passagem não seja feita de forma brusca. Como num passe de mágica, a união de mais de três décadas dos Verdurin cai no esquecimento, de forma a revelar as engrenagens de uma sociedade que se adapta constantemente de acordo com as conveniências do momento. Com a aceleração dos processos de transformação social, diminuise o rigor da transferência de títulos e, consequentemente, a exaltação da 
linhagem de sangue tão valorizada pelo discurso observado em Le côté de Guermantes. Se ali a enorme memória do duque de Guermantes, ao relatar sua genealogia quase milenar, é necessária para justificar a primazia social da família, aqui, após as reviravoltas do enredo, as lembranças devem ser efêmeras:

"Car la mémoire durait moins que la vie chez les individus, et d'ailleurs, de très jeunes, qui n'avaient jamais eu les souvenirs abolis chez les autres, faisant maintenant une partie du monde, et très légitimement, même au sens nobiliaire, les débuts étant oubliés ou ignorés, ils prenaient les gens au point d'élévation ou de chute où ils se trouvaient, croyant qu'il en avait toujours été ainsi, que Mme Swann et la princesse de Guermantes et Bloch avaient toujours eu la plus grande situation [...]"273

Como as mudanças do caleidoscópio social são inevitáveis, cabe às personagens submeterem-se a elas. As mais antigas do meio aristocrático, como a duquesa de Guermantes, fingem ter se esquecido das primeiras investidas de uma cocotte e de uma burguesa de modos caricatos, enquanto as recém-admitidas, representadas ao final por Bloch, devido a uma ignorância genuína, acreditam que Madame Verdurin, de ascendência Duras, sempre pertenceu à nobreza. Portanto, o esmaecimento do passado das duas figuras ocorre nas duas esferas de frequentadores do faubourg Saint-Germain: os veteranos fingem não se lembrar do histórico das arrivistas e os novos, por causa de verdadeiro desconhecimento, acreditam que elas integram, desde sempre, esse grupo exclusivo. A adoção do nome de origem fidalga Forcheville e Duras - facilita tanto o pretenso esquecimento quanto a aceitação dos relatos em vigência.

\footnotetext{
${ }^{273}$ Le Temps retrouvé, p. 536.
} 
Não podemos deixar de ressaltar o fato de que a voz narrativa participa, de certo modo, do espanto frente às mudanças. Com elas, o mundo da infância morre ou se torna decrépito, como as personagens que encontra na matinée final. Ali, forma-se a percepção da existência da sobreposição de situações sociais diferentes dispostas no decorrer do Tempo. ${ }^{274}$ Desse modo, o arrivismo réussi revela a força inabalável da História - mostrando as sucessivas reorganizações das classes dominantes decorrentes de fatos decisivos como o Affaire Dreyfus e a guerra -, que acaba por relativizar os privilégios da aristocracia e entroniza a burguesia.

Como estar no topo significa fazer parte de um círculo restrito e cobiçado, os grupos criam mecanismos para proteger-se. ${ }^{275}$ Daí, a necessidade de identificação entre os membros de determinado meio. Tanto nas obras cujas representações da sociedade são mais fechadas - $A$ mão e a luva, Helena e os três primeiros romances da Recherche - quanto nas que mostram um universo mais fluido - Quincas Borba e todos de Sodome et Gomorrhe em diante - , notamos que a integração do arrivista ocorre pela reprodução, mesmo que parcial, dos comportamentos tradicionais. As renovações trazidas por Odette e Madame Verdurin são inegáveis; contudo, a manutenção de hábitos sedimentados, entre eles a importância de pertencer a

\footnotetext{
${ }^{274}$ Le Temps retrouvé, p. 608.

${ }^{275}$ Guérin, Michel, op. cit., p.26. "[...] ceux qui ont la chance d'être 'nés' se protègent et en disputent l'accès à tous les autres. De cette masse amorphe et méprisée, les rares qui émergent et réunissent à s'introduire dans la 'société', ce plus petit des cercles concentriques dont le plus grand est le 'monde', doivent s'armer de patience et faire assaut d'habileté pour que les talents propres, qui les ont rendus remarquables et leur ont permis de se glisser dans le jardin défendu, acquièrent avec le temps, par le mariage et la possession, cette manière d'objectivité presque imperméable aux sous-entendus, magnifique et vulnérable, où jusqu'à Gastby, se detecte le parvenu."
} 
uma família de renome, faz-se necessária à preservação do brilho social da elite.

Substituição das personagens

Como vimos, a almejada adaptação das personagens arrivistas ao novo meio é um dos fatores fundamentais para o êxito do processo. Por ser um ambiente restrito e diminuto - no sentido de exclusivo -, há lugar para poucos. Nas representações das camadas superiores observadas nesses textos, se uma personagem ascende, outra deve sofrer um declínio. Desse modo, podemos dizer que o espaço e as posições sociais são perenes; o que está em constante movimento são as figuras que por eles transitam. Não constatamos, portanto, nenhum movimento intencional de subversão das estruturas consolidadas, mas sim a ocupação, por meio da substituição ${ }^{276}$, de uma posição já prestigiada, o que, em si, já corresponde a nuances sociais consideráveis.

Em A mão e a luva, Guiomar lança mão de toda a sua habilidade para ocupar uma função específica: a de filha da baronesa. Tal posição

\footnotetext{
${ }^{276}$ Acompanhamos aqui o pensamento de Michel Guérin a respeito da manutenção do jogo social e da substituição das figuras, na obra citada, p. 29: "[...]la substituition est une transgression douce, puisqu'elle ne discute pas l'ordre du monde mais valorise tel ou tel de ses ingrédients. [...] Elle déplace, échange, travestit même, mais elle n'as pas la prétention de changer le jeu en remplaçant ses figures par d'autres. L'arriviste, le premier, est un conservateur; il n'entend pas remettre en jeu la mise chèrement gagnée."
} 
preexiste à vinda da afilhada. Somente com o desaparecimento de Henriqueta da trama, por meio da morte, surge, conforme sabemos, uma possibilidade de ascensão para a protagonista.

No caso de Helena, verificamos esse procedimento de modo inverso. Há apenas a possibilidade de uma figura feminina ocupar o posto mais elevado, a saber, o de esposa de Estácio. Com a desistência da sociedade e da vida por parte da protagonista, fica subentendido que Eugênia cumprirá tal papel.

O bairro do Botafogo, em Quincas Borba, é o elemento invariável, pois se configura como o espaço ocupado por quem está no auge. Ao herdar a fortuna do amigo, Rubião transfere-se imediatamente para lá. A mesma região será a escolhida pelo casal Palha para estabelecer-se definitivamente. A evolução da construção do palacete será proporcional à derrocada do professor. A inauguração dos salões de Sofia e Cristiano coincide com o retorno do protagonista a Barbacena, sua cidade natal. Fecha-se uma casa, abre-se outra; e Botafogo persiste como ambiente dos privilegiados.

No desfecho da Recherche, as substituições são surpreendentes e significativas, pois unem dois meios antes incomunicáveis. A mesma Odette que não podia ser recebida pelas famílias respeitáveis, mesmo após o casamento com Swann, termina como amante de um dos maiores detentores das tradições aristocráticas. Além disso, ao posicionar-se ao lado do duque, Madame de Forcheville fica acima de Oriane de Guermantes, reviravolta inimaginável se levarmos em conta os relatos dos primeiros romances sobre a cocotte e a dama mais prestigiada do grand-monde parisiense. Aqui, a 
substituição se dá também pelos nomes, pois a situação social de cada figura não pode ser dissociada do título que carrega. ${ }^{277}$ Isso não ocorre em Machado, porque as obras brasileiras se concentram, principalmente, nas camadas burguesas, desvinculadas de tradições de linhagem como as descritas em Proust.

A escalada de Madame Verdurin pode ser considerada ainda mais espetacular. De total desconhecedora do modo de funcionamento das genealogias, a exemplo da emblemática cena com Charlus na Raspelière, a mecenas burguesa se apropria de um dos mais altos títulos mencionados na obra. A matinée final nos domínios dos príncipes de Guermantes funciona como um resumo ilustrado do amálgama social ocorrido nos últimos anos do período ficcionalizado na obra. Nessa recepção, os mundos opostos convergem, fazendo com que as figuras de todos os meios descritos anteriormente - burgueses e aristocráticos - compartilhem o mesmo espaço.

Com um proceder que combina manutenção da tradição (Madame Verdurin casa-se para obter o título de princesa de Guermantes) e renovação (o casal se estabelece na Avenida do Bois de Boulogne, fora do faubourg Saint-Germain), Madame Verdurin consegue o que sempre almejou: fazer parte do alto escalão social sem abrir mão da arte vanguardista e de alguns de seus antigos companheiros da época de suas primeiras investidas sociais. A cocotte e a Patronne deixam no passado as reuniões inexpressivas da Rua Montalivet

\footnotetext{
${ }^{277}$ GENETTE, Gérard. "Proust et le langage indirect" in Figures II. Paris: Seuil, 1979, p. 243. "La vie des noms se révèle être une suite de transmissions et d'usurpations qui ôte tout fondement à la rêverie onomastique: celui de Guermantes finira pour tomber en la possession de la très roturière Patronne, ex Verdurin; Odette est successivement Crécy, Swann, Forcheville; Gilberte, Swann, Forcheville, et Saint-Loup [...]"
} 
para tomarem o lugar das damas mais brilhantes, a duquesa e a princesa de Guermantes, ao lado dos respectivos maridos destas.

Maternidade

Tanto em Machado quanto em Proust, a questão da maternidade aparece atrelada de algum modo ao dado feminino do arrivismo.

A mão e a luva e Helena são romances constituídos predominantemente dentro dos limites da intimidade doméstica, de modo que a família funciona como modelo da ordem social e moral. ${ }^{278}$ Por isso, a manutenção do núcleo familiar, através da maternidade - ou seu substitutivo, nos casos de Guiomar e Helena - têm grande importância. Como já foi dito, essas obras não trazem um embate de classes efetivo, pois seu viés privilegia sobretudo a adequação e conformidade sociais de personagens nascidas abaixo de seu merecimento. Assim, os problemas e conflitos devem ser sempre resolvidos sob a tutela das matriarcas. ${ }^{279}$

Na Recherche, o uso da maternidade como degrau para a ascensão é flagrante. Numa espécie de encadeamento em que mãe e filha garantem a continuidade do carreirismo de ambas, a sucessão de manobras de uma e

\footnotetext{
${ }^{278}$ SCHWARZ, Roberto, op. cit., p. 89. "[...] a família, de preferência abastada, é a intocável depositária da ordem e do sentido da vida."

279 Ibidem, p. 90. "[...] os problemas decorrentes, à diferença do Realismo europeu, estão inscritos na órbita estreita e pia do sentimento doméstico."
} 
outra leva as duas ao topo da elite parisiense. Os casamentos de Odette com Swann e, posteriormente, com Forcheville permitem que elas sejam recebidas no faubourg Saint-Germain. Tal posição será consolidada com a união entre Gilberte e Saint-Loup, possibilitada somente a partir da mudança de nome para Forcheville.

Odette e Gilberte (cujos nomes têm uma ressonância sonora, em consonância com a trama) representam, portanto, a mesma moeda de troca (de posição, de nome) que redundará na figura a representar o coroamento do processo: Mademoiselle de Saint-Loup, resultado da maternidade final.

A cidade

Como as narrativas da primeira fase machadiana são elaboradas sob a "ótica da moral da família" ${ }^{280}$, a cidade não tem muita relevância, porque a interação com o outro, típica da cidade, se transfere para o trato da família e da maternidade e da 'não-publicidade' dos eventos, que se encontram submetidos à lógica do comedimento social.

Em Quincas Borba, por outro lado, o assunto da filiação aparece de forma muito discreta, devido ao fato de a trama ser engendrada em um ambiente mais urbano. Desde a chegada de Rubião à capital, forma-se uma

\footnotetext{
${ }^{280}$ MURICY, Kátia, op. cit., p. 65
} 
aura de encantamento e sedução em torno do Rio de Janeiro. ${ }^{281} \mathrm{~A}$ cidade, aqui, ocupa função primordial, pois os sucessos dos carreiristas são sempre avaliados através da comparação com as outras personagens. Daí a satisfação de Sofia ao exibir seus ombros e joias e de ser vista pelo major Siqueira passeando pela cidade de coupé. A demonstração ostensiva do luxo adquirido, sobretudo quando observada ao lado da estagnação social do círculo anterior de convivas, confirma o sucesso da trajetória perante os olhos que cercam a personagem arrivista.

No prefácio da terceira parte de Illusions perdues, Balzac ressalta a importância da cidade grande no contexto das narrativas que tratam da questão da mobilidade:

"L'esprit, l'argent et le grand nom viennent chercher la sphère qui leur est propre.[...] II reste à faire l'histoire du bourgeois enrichi à qui sa province déplaît, qui ne veut pas rester au milieu des témoins de ses commencements et espère être un personnage à Paris." ${ }^{282}$

Nesse sentido, a cidade se transforma no espaço privilegiado de atuação desse tipo de figura. Desde a determinação de Julien Sorel em ser relevante na esfera aristocrática da mansão de La Mole e a exclamação emblemática de Rastignac em Le père Goriot - À nous deux maintenant! -, o pertencimento a Paris se configura como principal objetivo. Em Quincas Borba e na Recherche, Rio de Janeiro e Paris afunilam-se em espaços ainda mais

\footnotetext{
${ }^{281}$ A esse respeito ver PASSOS, Gilberto Pinheiro. O Napoleão de Botafogo. Presença Francesa em Quincas Borba de Machado de Assis, capítulo III.

${ }^{282}$ BALZAC, Honoré de. Préface de la troisième partie. Illusions perdues. Paris, Garnier Frères, 1961, p. 765.
} 
diminutos e exclusivos, representados pelo faubourg Saint-Germain ${ }^{283}$ e por Botafogo, pois as movimentações sociais mais relevantes ocorrem dentro desses limites urbanos restritos os quais poucos conseguem penetrar. Por isso, Combray, Barbacena, e até Santa Teresa representam o contraponto da estabilidade, idealizada em Proust e desvalorizada no romance brasileiro.

Além da oposição cidade/província, observamos também a notável evolução dos salões menores, transformados, ao final, em espaços relevantes de seus contextos sociais. O casarão de Botafogo contrasta com a casa antiga de Santa Teresa, da mesma forma que a pequenez social da primeira recepção na Rua Montalivet fica evidente quando ela é comparada à dos duques e príncipes de Guermantes e à matinée final de Madame Verdurin, agora princesa $^{284}$. O estabelecimento da posição de prestígio na esfera mais elegante da cidade grande deve ser observado e admirado por todos, tal qual um espetáculo anseia ser visto e aplaudido pelo público.

${ }^{283}$ Em Le père Goriot, o narrador delimita o campo espacial pretendido por Rastignac: "Rastignac, resté seul, fit quelques pas vers le haut du cimetière et vit Paris tortueusement couché le long des deux rives de la Seine, où commençaient à briller les lumières. Ses yeux s'attachèrent presque avidement entre la colonne de la place Vendôme et le dôme des Invalides, là où vivait ce beau monde dans lequel il avait voulu pénétrer." BALZAC, Honoré de. La Comédie Humaine. Paris, Gallimard, 1976, p. 290. Bibliothèque de la Pléiade, III.

${ }^{284}$ A esse respeito, René Girard comenta: "Les salons n'existent qu'en fonction les uns des autres. Nous retrouvons, entre les collectivités que separe et unit tout à la fois la médiation double une dialectique du maître et de l'esclave semblable à celle qui régit ler apport entre les individus. Le salon Verdurin et le salon Guermantes luttent souterrainement por la maîtrise mondaine.", op. cit., p., 232. 
O tema e as formas

Em Machado, as personagens arrivistas femininas estão circunscritas à obra específica em que aparecem. Guiomar, Helena e Sofia desenvolvem-se por completo nos textos dos quais fazem parte. Estes apresentam ao leitor o curto período relativo ao ponto de virada da condição social dessas figuras. Salvo uma ou outra digressão concernente ao passado, o narrador foca um breve intervalo temporal - menos de um ano em $A$ mão e a luva e Helena e quatro anos em Quincas Borba - para mostrar os acontecimentos e gestos responsáveis por tal mudança. O resultado são romances concisos, como a fortuna crítica tem ressaltado repetidamente. Interessa-nos aqui não resgatar a sucessão de análises dedicadas ao estilo machadiano e sua filiação, pois as hipóteses levantadas são muito numerosas e variadas, de modo que correríamos o risco de desfocar o recorte deste estudo. No entanto, parece ser pertinente reter alguns comentários acerca da forma textual do escritor com o fim de associá-los ao nosso tema.

Em "Esquema de Machado de Assis", Antonio Candido ressalta que o autor "cultivou livremente o elíptico, o incompleto, o fragmentário" ${ }^{285}$, de maneira a propiciar "o estilo que mantém uma espécie de imparcialidade"286. Já Eugênio Gomes chama a atenção para o "microrrealismo" ${ }^{287}$ do romancista, do

\footnotetext{
${ }^{285}$ CANDIDO, Antonio. "Esquema de Machado de Assis" in Vários Escritos, p. 22. ${ }^{286}$ Ibidem.

${ }^{287}$ GOMES, Eugênio. "O microrrealismo de Machado de Assis" in BOSI, Alfredo et Al. Machado de Assis. São Paulo: Ática,1982, (Col. Escritores brasileiros:antologia e estudos:1), p. 369.
} 
qual decorre uma "hipérbole às avessas"288, ou seja, por diminuição, ilustrada pelo crítico com a seguinte citação do "Sermão da segunda dominga de Quaresma"(1651) de Padre Antônio Vieira:

"Há hipérbole por excesso e hipérbole por diminuição: e ambas mentem para chegar à verdade.[...] A hipérbole por excesso diz o muito que se não pode crer, para que se creia o que é: e a hipérbole por diminuição diz o pouco que se pode dizer, para que se creia o que será." 289

A forma sucinta de Machado se encaixa bem no tipo de arrivismo representado em sua obra. O autor aponta para seres em ascensão que não se vinculam a tradições nos moldes das francesas, porque o Brasil também não tem uma história social tão complexa - no sentido de estratificação - quanto a da França. A nobreza praticamente não aparece nos textos machadianos. A perspectiva é sobretudo a da burguesia rica (terratenente, escravocrata, financeira) que já funciona (para os arrivistas) como um patamar social a ser alcançado. O escritor respeita os limites da sociedade brasileira, em que a nobreza não possui a origem, os costumes, os preconceitos e o crédito social da aristocracia francesa. O universo apresentado não tem uma continuidade extensa, daí o fato de Guiomar e Helena ascenderem devido a sua superioridade natural e o casal Palha pelo ótimo aproveitamento das oportunidades surgidas com o aumento da fluidez social. Tudo isso em um curto intervalo temporal.

\footnotetext{
${ }^{288}$ GOMES, Eugênio, op. cit., 369.

289 Idem.
} 
O sentimento íntimo da nacionalidade, expresso pelo escritor brasileiro no texto "Instinto de nacionalidade"290, deságua na compreensão exata da magnitude das possíveis mudanças sociais de um país largamente escravocrata e de pouca movimentação de capitais industriais. Alencar já havia alertado para o provável descompasso entre nossas representações da realidade nacional e o mundo balzaquiano. ${ }^{291}$

Já o caráter fragmentário e elíptico parece dar conta da necessidade de um comportamento cauteloso do narrador. Este opta, nos três romances, por respeitar, pelo menos nas aparências, o decoro do ambiente das famílias paternalistas fluminenses. ${ }^{292}$ Por isso, os gestos de cálculo de Guiomar e Helena são construídos num movimento contínuo de afirmação e negação, e, mesmo o possível adultério de Sofia não se concretiza, fazendo com que as insinuações desta a Rubião e a Carlos Maria não comprometam a respeitabilidade de seu casamento. Os avanços de interesse e de sedução são, quase sempre, narrados sob a forma de sugestão, o que torna mais complexa tal figura feminina. Assim, como Guiomar e Helena apresentam, por parte do narrador, uma caracterização ambígua, em sua caminhada (conforme sabemos), Sofia ganha essa dimensão mais ampla, exatamente porque não se

\footnotetext{
${ }^{290}$ ASSIS, Machado de. Obra completa. Tomo II. Rio de janeiro: Editora Nova Aguilar, 1959, pp. 801-809.

${ }^{291}$ ALENCAR, José de. "Carta posfácio à Senhora" in Senhora/Iracema. São Paulo: Editora Scipione, 1994, p. 186.

292 CANDIDO, Antonio. "Esquema de Machado de Assis" in Vários Escritos, p. 23 "A sua técnica consiste em sugerir as coisas mais tremendas da maneira mais cândida (como os ironistas do séc. XVIII); ou em estabelecer um contraste entre a normalidade social dos fatos e anormalidade essencial; ou em sugerir, sob aparência do contrário, que o ato excepcional é normal, e anormal seria o ato corriqueiro. Aí está o motivo de sua modernidade, apesar do seu arcaísmo de superfície."
} 
caracteriza apenas pela ascensão almejada, carregando em si - e por contiguidade - algo de uma profunda inquietação e carência afetiva.

Se, segundo o exemplo proposto por Eugênio Gomes, os textos de Machado adotam a "hipérbole por diminuição", podemos sugerir o conceito de "hipérbole por excesso" para ilustrar a forma proustiana na Recherche. A obra francesa, como foi dito anteriormente, representa as transformações sociais ocorridas durantes quatro décadas. A nobreza, referência comportamental para as classes que estão abaixo dela, é quase imemorial, coincidindo com a Idade Média.

Machado trata predominantemente das burguesias, pequena, média e alta, ao passo que Proust trabalha com uma variedade muito maior dos estratos e suas sub-divisões. Há muitas aristocracias e muitas burguesias. Temos a nobreza de espada (os Guermantes), a imperial (os léna e a princesa Mathilde), a de província (os Cambremer); e também a burguesia financeira (Swann) e de altos funcionários públicos (o pai do narrador e Norpois). O narrador francês precisa dar conta de uma continuidade longa, plena de símbolos e significados. Por isso, ele se demora em cada personagem principal, em cada situação. A visão das personagens como um todo só pode ser alcançada e apreendida ao final da leitura dos sete volumes, com a soma dos eventos sucessivos. ${ }^{293}$

\footnotetext{
${ }^{293}$ GENETTE, Gérard. "Proust et le langage indirect" in Figures II, p. 55. "[...]le temps proustien n'est pas un écoulement, comme la durée bergsonienne, c'est une succession de moments isolés; de même, les personnages (et les groupes) n'évoluent pas: un beau jour, ils se retrouvent autres, comme si le temps se bornait à actualiser une pluralité qu'ils contenaient virtuellement de toute éternité."
} 
O próprio autor reivindicava para sua obra "o benefício da paciência"294 e das "relações feitas à distância"295. Segundo Robert Dreyfus, Proust a definiu assim: Mon oeuvre n'est pas microscopique, elle est télescopique. ${ }^{296}$ Olhando de longe, percebemos a totalidade de cenas que compõem determinada figura, assim como precisamos nos afastar para ver o conjunto de motivos que formam uma tapeçaria. Vemos Odette menina e vendida pela mãe, cocotte como a dame en rose, mãe de família ao tornar-se Madame Swann, casando-se com Forcheville e, por fim, amante do duque de Guermantes. Do mesmo modo, observamos Madame Verdurin, anfitriã ridícula de um pequeno salão igualmente cômico, seu período de transição na Raspelière, sua influência considerável como uma das rainhas dos anos de guerra e, finalmente, parte integrante da mais alta linhagem como princesa de Guermantes.

Além disso, devemos sempre considerar a noção da construção do romance como uma catedral ${ }^{297}$ ou sinfonia ${ }^{298}$, o que explicaria as várias retomadas dos temas, das personagens e das situações, como o constante retorno de uma frase musical, mais chaque fois changée, sur un rythme, un accompagnement différents, la même et pourtant autre, comme reviennent les choses dans la vie $[. . .]^{299}$

\footnotetext{
${ }^{294}$ p. GENETTE, Gérard. "Proust et le langage indirect" in Figures II, p. 58.

295 Ibidem.

${ }^{296}$ DREYFUS, Robert. Souvenirs sur Marcel Proust. Paris: Bernard Grasset, 1926, p. 300.

${ }^{297}$ Le Temps retrouvé, p. 610.

${ }^{298}$ La prisonnière, p. 763.

${ }^{299}$ Idem.
} 
Em Machado, observamos uma assimilação quase harmoniosa pela burguesia dominante daqueles que conseguiram chegar até ela. Não há grandes embates; Guiomar e Helena, apesar das dificuldades iniciais, são absorvidas de bom grado pelas famílias e Sofia e Cristiano, após se firmarem financeiramente, igualam-se rapidamente aos membros da camada superior. $\mathrm{Na}$ narrativa proustiana, o enfrentamento de classes e os preconceitos são patentes, de modo que as trajetórias bem-sucedidas de Odette e Madame Verdurin precisam ser longamente traçadas. Para que tais transformações sejam mais bem compreendidas, o narrador se demora a descrever os rituais tradicionais, suas renovações e substituições, pois está tratando da lenta mudança de hábitos culturais sedimentados ao longo de séculos.

O arrivismo de menor monta, portanto, é o resultado de uma fina percepção das possibilidades ficcionais aliadas às reais relações sócioeconômicas brasileiras, que Machado soube refletir, não por acaso, na figura de Rubião, que, apenas e tão somente como vítima de delírios, pôde buscar o mundo francês em sua mais alta caracterização de poder: ser o imperador Napoleão III.

Arrivismo feminino como articulador narrativo

Podemos dizer, ao relembrar as concepções de tema como "uma rede de associações significativas e recorrentes" ${ }^{300}$ e "o conjunto das conexões

${ }^{300}$ BERGEZ, Daniel, op. cit., p. 118. 
que a obra forma" ${ }^{301}$ propostas por Bergez, que o arrivismo feminino constitui um dos importantes eixos sobre os quais essas obras são organizadas. Vejamos alguns exemplos de como tais "associações" e "conexões" são construídas nos textos e o modo pelo qual a voz narrativa os articula.

Nas obras de Machado, observamos comportamentos distintos da narração em terceira pessoa. Em $A$ mão e a luva e Helena, todo o desenvolvimento das personagens se apoia na ambiguidade, em que o interesse aparece sempre atenuado pelo esquema narrativo que afirma e depois nega, de modo que não há afirmações peremptórias e, se as houver, são demolidas em seguida. Tal procedimento condiz com a visão de que a ambição, nesses casos, não se apresenta como defeito ${ }^{302}$, funcionando, pelo contrário, como forma de adequar socialmente personagens singulares, nascidas aquém de seu talento.

Em Quincas Borba, por outro lado, não há muito espaço para duplicidade, pois a composição das atitudes de Sofia, sobretudo quando contraposta ao declínio gradativo de Rubião, aponta para a ambição desprovida de escrúpulos, indiciada em muitos momentos da narrativa. Um dos exemplos mais significativos, nesse sentido, pode ser observado na caracterização da personagem como Tartufo de Molière. Ora, o recurso do intertexto parece aludir à atitude hipócrita, pois a sedução do falso devoto tem

\footnotetext{
${ }^{301}$ BERGEZ, Daniel, op. cit., p.119.

${ }^{302}$ Algo que o diálogo final entre Guiomar e Luís Alves explicita, A mão e a luva, p. 270:

"_ Vi que você era homem resoluto, disse a moça a Luís Alves, que, assentado, escutava.

_ Resoluto e ambicioso, ampliou Luís Alves sorrindo; você deve ter percebido que sou uma cousa e outra.
}

_ A ambição não é defeito.

_ Pelo contrário, é virtude; eu sinto que a tenho, e que hei de fazê-la vingar." 
como fim o interesse financeiro e o empenho filantrópico serve para promover o relevo social. $^{303}$

A dissimulação do casal Palha se intensifica ainda mais na sequência de cenas que compõem o desfecho. A simultaneidade temporal do baile no palacete de Botafogo e da fuga de Rubião para Barbacena - realçada pelo narrador através das expressões "No dia seguinte ao baile" ${ }^{304}$ e "estava em vésperas do baile"305 - faz com que tanto a opulência da festa quanto o fim miserável do protagonista sejam enfatizados. Tal efeito se produz por duplo contraste: um, entre as situações finais de Sofia e do protagonista e, outro, pela inversão dos papéis no decorrer da narrativa. As "ricas joias" ${ }^{306}$ ostentadas pela personagem são a prova de que ela, ao "tramar à maneira de Tartufo"307, sai vencedora do jogo: "Ao vencedor as batatas". Assim, a filosofia do Humanitismo, elaborada por Quincas Borba, passa do sentido figurado ao literal, pois Rubião, em seu delírio de morte ao exclamar repetidamente a suma de tal teoria, passa fome e frio, enquanto os antigos amigos promovem o baile "mais célebre do tempo". ${ }^{308}$

A inflexibilidade do narrador para com Rubião nas cenas finais parece revelar também, em certa medida, os meios de funcionamento da sociedade representada, na qual a posse dos recursos, adquirida inclusive por meios

\footnotetext{
${ }^{303}$ Recuperamos novamente a análise feita por Gilberto Pinheiro Passos em O Napoleão de Botafogo, pp. 54-56.

${ }^{304}$ Quincas Borba, 803.

${ }^{305}$ Idem, 804.

${ }^{306}$ Idem, 803.

307 PASSOS, Gilberto. O Napoleão de Botafogo. Presença francesa em Quincas Borba de Machado de Assis, p. 55.

${ }^{308}$ Quincas Borba, p. 803.
} 
espúrios, reorganiza os estratos, rebaixando uns e elevando outros. O idealismo presente em $A$ mão e a luva e Helena desaparece quase totalmente ${ }^{309}$, para dar lugar à crítica aguda e algo pessimista da natureza das relações humanas.

Na Recherche, por causa da predominância da narração em primeira pessoa, os vários aspectos e facetas do arrivismo se constroem aos poucos, à medida que o olhar do protagonista vive as experiências e busca compreender o mundo. ${ }^{310}$ Nesse sentido, a apreensão do universo dos Guermantes se mostra bastante reveladora. A aura de encanto simbolizada por essa família se constitui pelos olhos do narrador e seu fascínio burguês pela aristocracia e seus rituais. Sem suas impressões, não conseguiríamos compreender a admiração de Odette e Madame Verdurin por tal meio, pois elas só se aproximam dele no decênio final da narrativa.

A justificativa da hegemonia social desse grupo começa a se formar ainda na infância do herói. O primeiro contato se limita ao nome, ou seja, às impressões que ele causa em Marcel:

"C'était, ce Guermantes, comme le cadre d'un roman, un paysage imaginaire que j'avais peine à me représenter et d'autant plus le désir de découvrir, enclavé au milieu de terres et de route réelles qui tout à coup s'imprégneraient de particularités héraldiques [..]"311

\footnotetext{
${ }^{309}$ Dizemos “quase", pois D. Fernanda pode ser considerada exceção.

${ }^{310}$ Ver DELEUZE, Gilles, op. cit.

${ }^{311}$ Le Côté de Guermantes, p. 314.
} 
A vinculação do título à terra (à propriedade de campo) e à história faz com que o núcleo dos Guermantes seja associado a algo quase sagrado, inatingível e impenetrável, devido ao pertencimento a uma linhagem praticamente imemorial. ${ }^{312}$ Adolescente, morando em apartamento contíguo à propriedade dos duques, o narrador tem a oportunidade de observar os hábitos do casal, bem como a postura heráldica de Oriane, mesmo nos passeios a pé. Também, a cena da ópera, descrita pelo jovem iniciante na vida social, explica o caráter extraordinário desse segmento exclusivo da nobreza. Retratados como deuses e monstros marinhos, a separação entre esses descendentes de reis e rainhas do restante da sociedade parece ser, nesses primeiros momentos, absoluta, a exemplo do comentário abaixo:

"Mais ici, dans le premier salon [des Guermantes] du faubourg Saint-Germain, dans la galerie obscure, il n'y avait qu'eux. Ils étaient, en une matière précieuse, les colonnes qui soutenaient le temple, [...] les statues d'or des apôtres de la Sainte-Chapelle." 313

Esses lances, somados às recepções seguintes dos duques e dos príncipes de Guermantes, conformam o imaginário um tanto mágico do fauborg Saint-Germain. Assim, por meio do contraste deste meio com a pequenez do salão da Rua Montalivet, forma-se a percepção da ascensão espetacular de

\footnotetext{
312 POULET, Georges, op. cit., pp. 44, 45: "De cette curieuse interdépendance, à la fois topologique et anthropologique, le meilleur exemple est assurément celui des noms. Noms de famille, noms de pays, l'on sait le rôle immense qu'ils jouent dans l'oeuvre proustienne [...] Or, les noms de famille, et spécialement les noms de familles nobles, ont cette particularité d'être à la fois le nom d'un lieu et celui d'une personne, et d'amalgamer ainsi dans une identité unique les deux ingredients don't l'imagination proustienne a besoin."
}

${ }^{313}$ Le Côté de Guermantes, p., 331. 
Odette e Madame Verdurin. No entanto, tal apreensão só se completa nos momentos finais da obra. Como o conhecimento das diferentes classes ocorre gradativamente, através do olhar narrativo, a visão da totalidade dos meios sociais se torna possível somente com a junção dos diversos tempos e espaços que a compõem.

Voltando à sugestão de Álvaro Lins de que o romance pode ser mais bem compreendido se, após a leitura do último volume retornarmos ao primeiro, percebemos que a questão da divisão e união das classes burguesia e aristocracia - se enquadra perfeitamente na ideia de composição referida pelo narrador. Como sabemos, as últimas reflexões na matinée da princesa de Guermantes apontam para o início da escritura da obra, ou seja, para Du Côté de chez Swann, completando, dessa maneira, o círculo narrativo. Nesse sentido, a emblemática divisão do "mundo" entre os lados de Méséglise (Swann) e Guermantes, na infância de Marcel, será desfeita lentamente, ao longo das sete partes que compõem o texto, pois universos tão incompatíveis, assim como estão representados até Sodome et Gomorrhe, precisam de um longo intervalo de tempo para aproximar-se. Contudo, no começo de "Combray I", a lembrança do herói das temporadas na casa do avô materno e dos passeios em família pelos dois caminhos - e universos sociais - opostos vem à tona quando ele acorda no meio da noite, adulto, na propriedade de Madame de Saint-Loup. ${ }^{314}$ Essa temporada em Tansonville será retomada novamente apenas em Le temps retrouvé. Portanto, se em um plano o contato entre os salões Guermantes e Verdurin se constrói gradativamente, em outro, na leitura retrospectiva do romance, a fusão já se fez e está indicada pela presença do

\footnotetext{
${ }^{314}$ Du côté de chez Swann, pp., 6, 7.
} 
narrador nas terras de Gilberte, agora como uma das primeiras damas da aristocracia.

Em "Combray II", a cena da duquesa na igreja da cidade, por ocasião do casamento da filha do médico local, ${ }^{315}$ também revela a possível aproximação - social e espacial - dos núcleos. Assim, a junção dos meios, ainda que improvável nos momentos iniciais da saga, está indiciada nesses fatos. Portanto, se na percepção da criança há uma grande distância entre Méséglise e Guermantes, na vida adulta, cuja percepção foi transformada pelo tempo, o hóspede (Marcel) se dá conta de que tais porções de terra sempre foram vizinhas. O que muda não são os locais ou as personagens, mas a perspectiva decorrente das transformações históricas e sociais.

De todo modo, o protagonista-narrador da Recheche parece refletir, no que se refere ao contexto sócio-cultural francês, sobre o fim de uma era, na qual durante séculos, a aristocracia conseguiu manter o domínio do modelo de comportamento com sua tradição e seus rituais, mesmo após a Revolução Francesa. Apesar do extenso caminho percorrido por Odette e Madame Verdurin até o topo, a presença de figuras como elas no círculo mais restrito de Paris impressiona Marcel até o final. ${ }^{316}$ Tanto a primeira, ao tomar o lugar da duquesa na simbólica propriedade de Guermantes $^{317}$, quanto a segunda, ao

\footnotetext{
${ }^{315}$ Du côté de chez Swann, p. 172.

${ }^{316}$ Le temps retrouvé, p. 535. "Détendus ou brisés, les ressorts de la machine refoulante ne fonctionnaient plus, mille corps étrangers y pénétraient, lui ôtaient toute homogénéité, toute tenue, toute couleur. Le faubourg Saint-Germain, comme une douaurière gâteuse, ne répondait que par des sourires timides à des domestiques insolents qui envahissaient ses salons, buvaient son orangeade et lui présentaient leur maîtresses."

${ }^{317}$ Idem, p. 577. "Mme de Forcheville, revenue exprès de Guermantes, d'où la duchesse était à peu près expulsée [...]"
} 
apropriar-se de tal nome sem nem conhecer a longa história que ele carrega em si, numa espécie de usurpação do título ${ }^{318}$, atestam os giros do caleidoscópio social.

Em Machado, por outro lado, os enredos tratam predominantemente das esferas burguesas e dos possíveis contatos entre os diversos níveis que as compõem. Não obstante o fato de o Brasil ter uma vida sócio-cultural mais restrita que a França, o autor não deixa de tratar do tema do arrivismo redimensionando-o aos limites do país e de nossa história literária ${ }^{319}$ Como a sociedade retratada apresenta uma estratificação menos rígida que a francesa, a ascensão das personagens brasileiras não é tão espetacular se comparada às vistas na Recherche, ocorrendo em um intervalo temporal significativamente mais curto. Pela mesma razão, o domínio, por parte das figuras, dos códigos de comportamento necessários à adequação social ocorre mais facilmente. Mas, cumpre ressaltar, conforme mostram os romances estudados, que tais limitações não impedem o surgimento e o desenvolvimento dos conflitos de mudança de classe.

\footnotetext{
${ }^{318}$ Le Temps retrouvé, p. 533. "Quand elle eut épousé le prince de Guermantes, on dut se dire que c'était un faux Guermantes, un escroc. Pour moi, dans cette identité de titre, de nom, qui faisait qu'il y avait encore une princesse de Guermantes et qu'elle n'avait aucun rapport avec celle qui m'avait tant charmé et qui n'était plus là et qui était comme une morte sans défense à qui on l'eût volé [...] La succession au nom est triste comme toutes les successions, comme toutes les usurpations de propriété."

${ }^{319}$ Em "Instinto de nacionalidade", Machado chama a atenção para a jovialidade do país: "[...] tratando-se de um país que apenas entra na primeira mocidade" (p. 804) e de sua literatura: "Do romance puramente de análise, raríssimo exemplar temos, ou porque a nossa índole não nos chame para aí, ou porque seja esta casta de obras ainda incompatível com nossa adolescência literária."(p.805)
} 
Em A mão e a luva e Helena, obras cujo período ficcionalizado se insere nos anos 1850, a maior imobilidade faz com que o escritor situe as tramas dentro do âmbito doméstico, deslocando as questões urbanas, típicas do arrivismo, para o trato familiar. A combinação de ambição e virtude na constituição dos perfis de Guiomar e Helena revela a grande habilidade de Machado, pois, ao atenuar a crueza do tema, ele consegue adequá-lo aos padrões impostos pela sociedade paternalista brasileira. Em Quincas Borba, por outro lado, observamos a representação de um Rio de Janeiro mais movimentado, onde as relações interpessoais são travadas com mais facilidade, como exemplificam as variadas conexões presentes na narrativa: entre Rubião e o casal Palha, Cristiano e o diretor de banco e Sofia e D. Fernanda. Aqui, a dupla de arrivistas, condizente com a conjuntura retratada, pode servir-se da maior fluidez social para estabelecer vínculos úteis ao projeto de ascensão, ensejados, inclusive, pela exposição pública do corpo da mulher. Portanto, em oposição à limitação doméstica das obras anteriores, o sucesso de Cristiano e Sofia decorre essencialmente das associações formadas na esfera urbana. Nesse ponto, a despeito das diferenças já assinaladas, este romance se aproxima mais da Recherche, pois coloca a cidade como cenário indispensável ao desenvolvimento dessas personagens. 


\section{Bibliografia}

\section{I) Machadiana:}

BOSI, Alfredo. "Figuras do narrador machadiano" in Cadernos de Literatura Brasileira, n. 23/24, jul 2008, Instituto Moreira Salles, São Paulo. . O enigma do olhar. São Paulo, Editora Ática, 1999.

BOSI, Alfredo. "A máscara e a fenda" in BOSI, Alfredo et Al. Machado de Assis. São Paulo: Ática, 1982, (Col. Escritores brasileiros:antologia e estudos:1).

CALDWELL, Helen. Machado de Assis. The Brazilian Master and his novels. University of California Press, 1970.

CANDIDO, Antonio. "Esquema de Machado de Assis" in Vários Escritos. São Paulo/Rio de Janeiro: Duas Cidades/Ouro sobre Azul, 2004.

GLEDSON, John. Machado de Assis: Ficção e História. São Paulo, Paz e Terra, 2003.

GOMES, Eugênio. "O microrrealismo de Machado de Assis" in BOSI, Alfredo et Al. Machado de Assis. São Paulo: Ática, 1982, (Col. Escritores brasileiros:antologia e estudos:1).

MACHADO, Ubiratan. Bibliografia Machadiana. 1959 -2003. São Paulo: Edusp, 2005.

MURICY, Kátia. A razão cética. Machado de Assis e as questões de seu tempo. São Paulo: Companhia das Letras, 1988.

PASSOS, Gilberto Pinheiro. Capitu e a mulher faltal. Análise da presença francesa em Dom Casmurro. São Paulo: Nankin Editorial, 2003.

. O Napoleão de Botafogo: presença francesa em Quincas Borba de Machado de Assis. São Paulo: Annablume, 2000.

PEREIRA, Lúcia Miguel. Machado de Assis. Estudo crítico e biográfico. Editora Itatiaia Limitada, Edusp, 1998. 
Prosa de Ficção (de 1870 a 1920). História da Literatura Brasileira.

Editora Itatiaia Limitada, Edusp, 1998.

SCHWARZ. Roberto. Ao vencedor as batatas. São Paulo: Duas Cidades/ Editora 34, 2000.

STEIN, Ingrid. Figuras femininas em Machado de Assis. Rio de Janeiro: Paz e Terra, 1984.

\section{II) Proustiana:}

BARTHES, Roland et Al. Recherche de Proust. Paris: Éditions du Seuil, 1980.

BÉHAR, Henri. À la recherche du temps perdu. Analyse de l'oeuvre. Paris: Pocket, 2006.

BIDOU-ZACHARIASEN, Catherine. Proust sociologue. De la maison aristocratique au salon bourgeois. Paris: Descartes et Cie, 1997.

COMPAGNON, Antoine. Proust entre deux siècles. Paris: Éditions du Seuil, 1989.

COUDERT, Raymonde. Proust au féminin. Paris : Bernard Grasset/ Le Monde de l' Éducation, 1998.

DELEUZE, Gilles. Proust e os signos. Rio de Janeiro: Forense-Universitária, 1987.

DREYFUS, Robert. Souvenirs sur Marcel Proust. Paris: Bernard Grasset, 1926.

ERMAN, Michel. Le Bottin des lieux proustiens. Paris: Éditions de La Table Ronde, 2011.

. Le Bottin proustien. Paris: Éditions de La Table Ronde, 2001.

GAMBLE, Cynthia. "From 'Belle Époque' to Fisrt World War: the social panorama" in BALES, Richard (ed.) The Cambridge Companion to Proust. Cambridge University Press, 2001.

GENETTE, Gérard. "Proust Palimpsesto" in Figuras. São Paulo: Perspectiva, 1972. 
. "Proust et le langage indirect" in Figures II. Paris: Seuil, 1979.

HUGUES, Edward. "Proust and social spaces" in BALES, Richard (ed.) The Cambridge Companion to Proust. Cambridge University Press, 2001.

KRISTEVA, Julia. Le temps sensible. Proust et l'expérience littéraire. Paris: Éditions Gallimard, 1994.

LAGET, Thierry. Du Côté de chez Swann de Marcel Proust. Paris, Éditions Gallimard, Col. Foliothèque 21, 1992.

LINS, Álvaro. Da técnica do romance em Marcel Proust. Rio de Janeiro: edição reservada feita pelo autor como tese apresentada a concurso para uma das cátedras de Literatura do Colégio Pedro II, 1950.

MAUROIS, André. Em busca de Marcel Proust. São Paulo: Editora Siciliano, 1995.

ORIOL, Judith. Femmes proustiennes. Bucarest: EST, 2009.

POULET, Georges. L'espace proustien. Paris: Éditions Gallimard, 1963.

PROUST, Marcel. Contre Sainte-Beuve précédé de Pastiches et mélanges et suivi de Essais et articles. Paris: Bibliothèque de La Pléiade, Éditions Gallimard, 1971.

SAIKI, Shinichi. Paris dans le roman de Proust. Paris: Éditions SEDES, 1996.

SCHMID, Marion. Proust dans la décadence. Paris: Honoré Champion Éditions, 2008. Études de style. Paris: Éditions Gallimard, 1970

SPITZER, Leo. "Le style de Marcel Proust" in Études de style. Paris: Éditions Gallimard, 1970.

\section{III) Teoria literária e literatura comparada:}

BADIR, Sémir. "Qu-est-ce qu'un thème? Une approche sémiologique". Signata 5 (2014). Annales de Sémiotiques. Littérature et sémiotique: histoire et épistémologie. Presses Universitaire de Liège, 2015. 
BERGEZ, Daniel et alli. Métodos críticos para a análise literária. São Paulo, Martins Fontes, 1997.

BRUNEL, P. PICHOIS, Cl. ROUSSEAU, A.M. Que é literatura comparada? São Paulo: Editora Perspectiva, 1995.

CANDIDO, Antonio. "Crítica e sociologia" in Literatura e sociedade. São Paulo: Companhia Editora Nacional, 1975. $4^{\mathrm{a}}$ Ed.

. O observado literário. Rio de Janeiro: Ouro sobre Azul, 2004.

CHEVREL, Yves. La littérature comparée. Paris: Presses Universitaires de France, $1989,5^{a}$ édition.

CLAUDON, Francis. HADDAD-WOTLING, Karen. Précis de littérature comparée. Théories et méthodes de l'approche comparatiste. Paris: Armand Colin, 2004.

GIRARD, René. Mensonge romantique et vérité romanesque. Paris: Bernard Grasset Editeur, 1961.

MACHADO, A. M. \& PAGEAUX, D-H. Da literatura comparada à teoria da literatura. Lisboa: Edições 70, 1988.

PACHECO, João. A literatura brasileira. Vol.3. O realismo. São Paulo: Editora Cultrix, s.d.

POULET, Georges. Trois essais de mythologie romantique. Saint-Brieuc, Librairie José Corti, 1966.

\section{IV) História e cultura brasileiras:}

ALECASTRO, Luiz Felipe de. NOVAIS, Fernando A. História da vida privada no Brasil Vo. 2. Império: A corte e a modernidade nacional. São Paulo: Companhia das Letras, 1997.

CALDEIRA, Jorge. Mauá. Empresário de Império. São Paulo: Companhia das Letras, 1996. 
CANDIDO, Antonio. "The Brazilian Family" in Brazil - Portrait of half a continente. New York: The Dryden Press, 1951.

D'INCAO, Maria Ângela. "Mulher e família burguesa" in PRIORE, Mary del. (org.) História das mulheres no Brasil. São Paulo: Editora Contexto, 2000.

IGLÉSIAS, Francisco et Al. História geral da civilização brasileira; t.2; vol. 5 . O Brasil Monárquico: Reações e transações. Direção e introdução geral de Sérgio Buarque de Holanda. Rio de Janeiro: Editora Bertrand Brasil, 1997.

LEITE, Miriam Moreira. A condição feminina no Rio de Janeiro no século XIX. São Paulo / Brasília: Editora HUCITEC - INL, Fundação Nacional Pró-Memória, 1984.

PINHO, Wanderley. Salões e damas do Segundo Reinado. Livraria Martins, 1970.

SAFFIOTI, Heleieth I. B. A mulher na sociedade de classes: mito e realidade. Petrópolis: Vozes, 1979.

\section{V) História e cultura francesas:}

BRELOT, Claude-Isabelle. "Entre nationalisme et cosmopolitisme: les engagements multiplex de la noblesse" in BIRNBAUM, Pierre (dir.). La France de l'Affaire Dreyfus. Paris: Gallimard, 1994.

GOUBERT, Pierre. História concisa de França. Portugal: Publicações EuropaAmérica, 1996.

GUÉRIN, Michel. La grande dispute. Essai sur l'ambition, Stendhal et le XIXe siècle. Actes Sud, 2006.

MARTIN-FUGIER, Anne. Les salons de la Ille République - Art, littérature, politique. Perrin, 2003 et 2009 pour la presente édition.

PACAUD, Serge. Vie Quotidienne des Français à la Belle Époque. Paris: CPE, 2008.

WINOCK, Michel. La Belle Époque. La France de 1900 à 1914. Perrin, 2002. 


\section{V) Outras fontes:}

ALENCAR, José de. "Carta posfácio à Senhora" in Senhora/Iracema. São Paulo: Editora Scipione, 1994.

BALZAC, Honoré de. Les secrets de la princesse de Cadignan in La Comédie Humaine, Bibliothèque de La Pléiade, 1936, vol. VI.

. Le père Goriot in La Comédie Humaine. Paris, Gallimard, 1976. Bibliothèque de la Pléiade, III.

- Préface de la troisième partie. Illusions perdues. Paris, Garnier Frères, 1961.

BEAUMARCHAIS, Pierre A. C. de. As Bodas de Fígaro. Trad. Barbara Heliodora. São Paulo: Edusp, 2001.

CUNHA, Antônio Geraldo da. Dicionário Etimológico da Língua Portuguesa. Rio de Janeiro: Nova Fronteira, 1982.

MOLIÈRE. Le Tartuffe. 24 ed. Paris: Larousse, s.d.

RÉGNIER, Henri de. Donc. Paris: Éditions du Sagittaire, 1927.

SOUZA, Gilda de Mello e. O espírito das roupas. A moda no século dezenove. São Paulo: Companhia das Letras, 1987.

STENDHAL. Le rouge et le noir in Oeuvres romanesques complètes. Paris: Bibliothèque de La Pléiade, Éditions Gallimard, 2005, tome I.

TASSO, Torquato. (trad. COELHO, José Ramos/ LUCCHESI, Marco) Jerusalém libertada. Rio de Janeiro: Topbooks, 1998. 